Przegląd Narodowościowy / Review of Nationalities • nr 7/2017 • World of Slavs / Świat Słowian

\title{
An outline of the actions of the communist security apparatus against the Ukrainian population in Ziemia Lubuska in 1947-1989
}

\author{
Zarys działań komunistycznego aparatu bezpieczeństwa \\ wobec ludności ukraińskiej na Ziemi Lubuskiej w latach 1947-1989
}

Keywords: Ziemia Lubuska, communist security apparatus, Ukrainian people

Settled in the area of Ziemia Lubuska (also called Middle Odra - Środkowe Nadodrze, equivalent to the Zielona Góra province within the borders of 1950-1975), the Ukrainian population was in the sphere of interest of the communist security authorities ${ }^{1}$. It was viewed in terms of a "precarious element" and in extreme cases even an "internal enemy" requiring permanent and multifaceted operational control. The historical circumstances (especially the socalled "war") were determined by the nationality policy of the government, which assumed gradual ethnic unification of the state, the non-democratic nature of the

${ }^{1}$ Materials used in the outline have already been published in articles: A. Słabig, Od rozpracowania "elementów bandyckich" do przyspieszenia "naturalnej" asymilacji. Zarys działań aparatu bezpieczeństwa wobec Ukraińców na Ziemi Lubuskiej w latach 19471970, [in:] Przed i po akcji "Wista", edit. A. Chabasińska, P. Leszczyński, B. Orłowska, M. Pecuch, Gorzów Wielkopolski 2012, pp. 41-64; idem, W kręgu sprawy pod kryptonimem "Beta". Ludność ukraińska na Ziemi Lubuskiej w latach 1970-1980 wświetle materiałów Stużby Bezpieczeństwa, "Studia Zachodnie" 2012, No. 14, pp. 211-242.
Słowa kluczowe: Ziemia Lubuska, komunistyczny aparat bezpieczeństwa, ludność ukraińska

Osiedlona na obszarze Ziemi Lubuskiej (zwanej też Środkowym Nadodrzem, tożsamej z województwem zielonogórskim w granicach z lat 1950-1975) ludność ukraińska znalazła się w sferze zainteresowania komunistycznych organów bezpieczeństwa ${ }^{1}$. Postrzegano ją w kategoriach „elementu niepewnego", a w skrajnych przypadkach nawet „wroga wewnętrznego”, wymagającego permanentnej i wielopłaszczyznowej kontroli operacyjnej. Zadecydowały o tym uwarunkowania historyczne (przede wszystkim tzw. zaszłości wojenne), polityka narodowościowa władz

1 Materiały wykorzystane w niniejszym szkicu były już publikowane w następujących artykułach: A. Słabig, Od rozpracowania „elementów bandyckich” do przyspieszenia „naturalnej” asymilacji. Zarys działań aparatu bezpieczeństwa wobec Ukraińców na Ziemi Lubuskiej w latach 1947-1970, [w:] Przed i po akcji „Wisła”, red. A. Chabasińska, P. Leszczyński, B. Orłowska, M. Pecuch, Gorzów Wielkopolski 2012, s. 41-64; idem, W kręgu sprawy pod kryptonimem „Beta”. Ludność ukraińska na Ziemi Lubuskiej w latach 1970-1980 w świetle materiałów Służby Bezpieczeństwa, „Studia Zachodnie” 2012, nr 14, s. 211-242.

* Correspondence address: Instytut Historii i Politologii, Akademia Pomorska w Słupsku, ul. Arciszewskiego 22a, 76-200 Słupsk, e-mail: aslabig@poczta.onet.pl. 
then Polish political system dominated by the Communist Party, the lack of sovereignty and dependence on the powerful eastern neighbor and the engagement in global competition, feuding politicalmilitary blocks.

The peak period of operation of the security apparatus (initially referred to as the Security Office [UB], subordinated to the central level of the Ministry of Public Security [MBP] and later to the Public Security Committee [KdsBP]) is 1948-1954. It was characterized by, as pointed out by Jarosław Syrnyk, the highest rate of employment in the ministry, the apogee of the development of the agent network, the highest co-financing rate in relation to the total state budget, and finally the greatest number of people subjected to the pressure of the political police. The activities of the security organs covered all areas of political, social, economic, educational and religious life ${ }^{2}$. After the transitional weakening of the "security", resulting from the destabilization of the then political system, under Władysław Gomułka’s rule, it was promptly rebuilt in the midst of the fifties. The Security Authorities (now known as the Security Service $[\mathrm{SB}]$ ), incorporated in November 1956 into the structures of the Ministry of the Interior (MSW), adapted themselves skillfully to the changed socio-political conditions. The level of staff training increased, and primitive force and chaotic operations were replaced by systematic, programmatic control of all the

2 J. Syrnyk, "Po linii” rewizjonizmu, nacjonalizmu, syjonizmu... Aparat bezpieczeństwa wobec ludności niepolskiej na Dolnym Ślasku (1945-1989), Wrocław 2013, p. 46. zakładająca stopniowe ujednolicenie etniczne państwa, niedemokratyczny charakter ówczesnego polskiego systemu politycznego zdominowanego przez partię komunistyczną, brak suwerenności i uzależnienie od potężnego, wschodniego sąsiada, a także uwikłanie w globalną rywalizację zwaśnionych bloków polityczno-militarnych.

Szczytowy okres działalności aparatu bezpieczeństwa (początkowo określanego jako Urząd Bezpieczeństwa [UB], podporządkowanego na szczeblu centralnym Ministerstwu Bezpieczeństwa Publicznego [MBP], a później Komitetowi ds. Bezpieczeństwa Publicznego [KdsBP]) przypada na lata 1948-1954. Charakteryzował się on - jak stwierdził Jarosław Syrnyk najwyższym wskaźnikiem zatrudnienia $\mathrm{w}$ resorcie, apogeum rozwoju sieci agenturalnej, najwyższym współczynnikiem dofinansowania w stosunku do całości budżetu państwa i wreszcie bodaj największą liczbą osób poddanych presji policji politycznej. Działalność organów bezpieczeństwa obejmowała wszystkie dziedziny życia politycznego, społecznego, gospodarczego, oświatowego i religijnego ${ }^{2}$. Po datowanym na połowę lat 50. przejściowym osłabieniu „bezpieki”, wynikającym z destabilizacji („,rozhermetyzowania”) ówczesnego systemu politycznego, pod rządami Władysława Gomułki nastąpiła szybka odbudowa jej pozycji. Organy bezpieczeństwa (znane odtąd jako Służba Bezpieczeństwa [SB]), wkomponowane

2 J. Syrnyk, „Po linii” rewizjonizmu, nacjonalizmu, syjonizmu... Aparat bezpieczeństwa wobec ludności niepolskiej na Dolnym Śląsku (1945-1989), Wrocław 2013, s. 46. 
separable fields of social life ${ }^{3}$. Secret surveillance included both the activities of official structures and the lives of private citizens. The collected information provided the basis for preventive and repressive actions in line with the interests of the then state. In this sphere, they cooperated closely with party and administrative apparatus.

Comprehensive operative work on Ukrainians was conducted with varying intensity since the beginning of the People's Republic of Poland until its end. Standard actions, which were also applied to Polish circles considered as opposition, in this case were intended not only to "neutralize" anti-systemic behaviors, but also to accelerate integration and assimilation processes. Repression of alleged nationalists, limitation of contacts with compatriots abroad, and paralysis of social and religious activity were effective measures to speed up the loss of national, cultural and religious diversity. It is clear from the available archival materials that the activity of the SB in the national field did not expire until the first half of 1990, with the liquidation of the communist political police.

In the period from May 26 to August 16,1947 , within the framework of the "Vistula" operation, 10,870 people belonging to the Ukrainian population were settled in Ziemia Lubuska ${ }^{4}$. The local structures of the security apparatus applied to them

3 Ibidem, pp. 55-56.

4 Ukrainian displaced persons in the Zielona Góra province came mainly from the Lemko region (i.e. the counties of Nowy Sącz, Gorlice, Jasielsk and Krosno), to a lesser degree also from Nadsanie (Sanok and Lesko counties) and Chełm region (Tomaszów county) (Appendix No. 5, Distribution of transports with the Ukrainian people deported to the northern and western Polish regions between od listopada 1956 r. w struktury Ministerstwa Spraw Wewnętrznych (MSW), umiejętnie dopasowały się do zmienionych warunków społeczno-politycznych. Wzrósł poziom wyszkolenia kadr, a prymitywną siłę i chaotyczne działania operacyjne zastąpiono systematycznym, programowym kontrolowaniem wszystkich dających się wyodrębnić dziedzin życia społecznego ${ }^{3}$. Tajnym nadzorem objęto zarówno działalność oficjalnych struktur, jak i życie prywatne obywateli. Zgromadzone informacje były podstawą do podjęcia działań profilaktycznych i represyjnych zgodnych z interesem ówczesnego państwa. W tej sferze ściśle współdziałano $\mathrm{z}$ aparatem partyjnym i administracyjnym.

Kompleksowa praca operacyjna wobec Ukraińców była prowadzona z różnym natężeniem od zarania Polski Ludowej aż po jej kres. Standardowe działania, które stosowano także wobec polskich środowisk uznanych za opozycyjne, $w$ tym przypadku miały nie tylko „zneutralizować” zachowania antysystemowe, ale też przyspieszyć procesy integracyjne i asymilacyjne. Represjonowanie rzekomych nacjonalistów, ograniczenie kontaktów z rodakami za granicą, a także paraliżowanie działalności społecznej i religijnej były skutecznymi środkami przyspieszającymi utratę odrębności narodowej, kulturowej i wyznaniowej. Z dostępnych dziś materiałów archiwalnych wynika, że aktywność SB „na odcinku" narodowościowym wygasła dopiero w pierwszej połowie $1990 \mathrm{r}$., wraz z likwidacją komunistycznej policji politycznej.

\footnotetext{
3 Ibidem, s. 55-56.
} 
two terms: "displaced persons from the 'W' operation (in the Poznań province) and 'Dniestr' community" (in the Wrocław province $)^{5}$. Their invigilation was initiated on the basis of the instructions issued at the end of April 1947 by the MBP Department III leadership. Operational activities across the country were also to cover the communities resulting from past political and economic migration together with Greek-Catholic clergy. It was suggested that they were the backbone of OUN intelligence, conspiratorial contact points, and in the border area also transfer points. At the same time, they were instructed to "pick up carefully" the members of the underground who had fled from the southeast of the country $y^{6}$. Special attention was also paid to the Ukrainian settlers who were detained in secluded areas before arriving in Środkowe Nadodrze were prisoners of the Central Labor Camp in Jaworzno (in January-February 1948, at least 72 former detainees were sent to "Lubuskie" counties of the Poznań province) ${ }^{7}$ and veterans of the Ukrainian nationalist move-

May 1 and August 16, 1947), [in:] Akcja "Wista". Dokumenty, edit. E. Misiło, Warszawa 1993, p. 447).

${ }^{5}$ Archive of the Institue of National Remeberance (AINR) Po, 0038/35, Vol. 1, Charakterystyka osób narodowości ukraińskiej osiedlonych na terenie powiatu gorzowskiego, 25 VII 1947, p. 224; AINR Po, 0038/35, Vol. 2, Alfabetyczny spis osób ze środowiska "Dniestr" wg rozeznania terenowego, n.d., pp. 150-164.

6 AINR Po, 0038/27/14, Instrukcja Departamentu III MBP w sprawie zwalczania działalności Organizacji Ukraińskich Nacjonalistów, 25 IV 1947, pp. 29-30.

7 A. Słabig, Od rozpracowania "elementów bandyckich" do przyspieszenia "naturalnej" asymilacji..., p. 42.
W okresie od 26 maja do 16 sierpnia 1947 r. w ramach akcji „Wisła” osiedlono na Ziemi Lubuskiej 10870 osób zaliczanych do ludności ukraińskiej ${ }^{4}$. Lokalne struktury aparatu bezpieczeństwa stosowały wobec nich dwa określenia: „przesiedleńcy $\mathrm{z}$ akcji «W»" (w województwie poznańskim) i „środowisko «Dniestr»" (w województwie wrocławskim) $)^{5}$. Ich rozpracowanie wszczęto na podstawie instrukcji wydanej pod koniec kwietnia 1947 r. przez kierownictwo Departamentu III MBP. Działania operacyjne prowadzone w skali całego kraju miały objąć też środowiska powstałe w wyniku dawnych migracji politycznych i zarobkowych wraz z duchowieństwem greckokatolickim. Sugerowano, że stanowią one zaplecze komórek wywiadowczych OUN, konspiracyjnych punktów kontaktowych, a w strefie przygranicznej także punktów przerzutowych. Równocześnie polecono „skrzętnie wyłapywać" członków podziemia, którzy zbiegli z południowego wschodu kraju ${ }^{6}$. Szczególnemu nadzorowi podlegały też osadni-

${ }^{4}$ Przesiedleńcy ukraińscy w Zielonogórskiem pochodzili przede wszystkim z terenów Łemkowszczyzny (czyli powiatów nowosądeckiego, gorlickiego, jasielskiego i krośnieńskiego), w mniejszym stopniu także z Nadsania (powiatów sanockiego i leskiego) i Chełmszczyzny (powiat tomaszowski) (Załącznik nr 5, Rozmieszczenie transportów z ludnością ukraińską wysiedloną do województw północnej i zachodniej Polski w okresie od 1 maja do 16 sierpnia 1947 r., [w:] Akcja, Wista”. Dokumenty, oprac. E. Misiło, Warszawa 1993, s. 447).

${ }^{5}$ AIPN Po, 0038/35, t. 1, Charakterystyka osób narodowości ukraińskiej osiedlonych na terenie powiatu gorzowskiego, 25 VII 1947, k. 224; AIPN Po, 0038/35, t. 2, Alfabetyczny spis osób ze środowiska „Dniestr" wg rozeznania terenowego, b.d., k. 150-164.

${ }^{6}$ AIPN Po, 0038/27/14, Instrukcja Departamentu III MBP w sprawie zwalczania działalności Organizacji Ukraińskich Nacjonalistów, 25 IV 1947, k. 29-30. 
ment who had their sentence in the labor camps in the Union Soviet until $1955^{8}$.

Initially, the primary task of the county posts of the security apparatus was to enforce regulations that prevented a change of place of residence and return home. Often, preventive measures were used in the form of night-time checks in the homes of displaced people carried out by the Security Office, the Civic Militia and sometimes by the Internal Security Corps 9 . Equally successful were the arrests of people who came from other counties "as if" to visit relatives and friends ${ }^{10}$.

UB members also supervised the legitimate efforts of Ukrainians to return. They controlled the correspondence sent to the county and province authorities, the Office of the Council of Ministers and the office of the President of the Republic of Poland. They verified both the senders of the letters (belonging to a specific category of displaced persons, possible compromising materials or agency activities for $\mathrm{UB}$, underground relationships, punishments, including stay at the Central Labor Camp in Jaworzno) and the content of consignments (credibility of the declared causes of dissatisfaction). In some cases, local authorities were suggested to pro-

8 The Ukrainian "repatriates" settled in Zielona Góra were attributed to the alleged members of conspiratorial Union of Prisoners of Freedom of Ukraine Więźniów Ukrainy (AINR Po, 0038/27, vol. 1, Kontrwywiadowcza charakterystyka nacjonalizmu ukraińskiego na terenie województwa zielonogórskiego, 13 I 1960, p. 32).

9 AINR Sz, 0103/25, Raport dekadowy kierownika PUBP w Kołobrzegu za okres 25 VI 1947-7 VII 1947, p. 102.

10 Ibidem, Raport dekadowy kierownika PUBP w Kołobrzegu za okres 25 X-5 XI 1947, p. 155. cy ukraińscy, którzy przed przybyciem na teren Środkowego Nadodrza byli przetrzymywani w miejscach odosobnienia. Mowa tu o więźniach Centralnego Obozu Pracy w Jaworznie (w okresie styczeń-luty $1948 \mathrm{r}$. wysłano do „lubuskich” powiatów Poznańskiego co najmniej 72 byłych aresztantów) ${ }^{7}$ oraz weteranach ukraińskiego ruchu nacjonalistycznego odbywających do $1955 \mathrm{r}$. wieloletnie wyroki pozbawienia wolności w obozach pracy w Związku Radzieckim ${ }^{8}$.

Początkowo podstawowym zadaniem powiatowych ogniw aparatu bezpieczeństwa było egzekwowanie przepisów uniemożliwiających zmianę miejsca osiedlenia i powrót w ojczyste strony. Częstokroć stosowano środki zapobiegawcze w postaci nocnych kontroli $w$ domach przesiedleńców przeprowadzanych siłami Urzędu Bezpieczeństwa, Milicji Obywatelskiej i niekiedy Korpusu Bezpieczeństwa Wewnętrznego' ${ }^{9}$. Równie skuteczne okazały się aresztowania osób, które przybyły z innych powiatów ,jakoby" celem odwiedzin krewnych i znajomych ${ }^{10}$.

Funkcjonariusze UB nadzorowali też legalne starania Ukraińców o powrót. Kontrolowali korespondencję wysyłaną

${ }^{7}$ A. Słabig, Od rozpracowania „elementów bandyckich" do przyspieszenia ,naturalnej" asymilacji..., s. 42 .

${ }^{8}$ Osiedlonym w Zielonogórskiem ukraińskim „repatriantom” przypisywano przynależność w łagrach do rzekomego konspiracyjnego Związku Wyzwolenia Więźniów Ukrainy (AIPN Po, 0038/27, t. 1, Kontrwywiadowcza charakterystyka nacjonalizmu ukraińskiego na terenie województwa zielonogórskiego, 13 I 1960, k. 32).

9 AIPN Sz, 0103/25, Raport dekadowy kierownika PUBP w Kołobrzegu za okres 25 VI 1947-7 VII 1947, k. 102.

${ }^{10}$ Ibidem, Raport dekadowy kierownika PUBP w Kołobrzegu za okres 25 X-5 XI 1947, k. 155. 
vide financial assistance to the petition$\mathrm{ers}^{11}$. Approving or rejecting the application for return to the eastern provinces was the sole responsibility of the Department III of $\mathrm{MBP}^{12}$. At the same time, they began the search for the so-called inspirers of sentimental moods and those who undertook to write letters on behalf of displaced persons, who often could hardly write in the Polish language ${ }^{13}$.

At the moment of stabilization of the Ukrainian settlement, of prime importance was the action of finding and arresting hiding former soldiers of the Ukrainian Insurgent Army (UPA) and activists of the Organization of Ukrainian Nationalists (OUN) on the so-called Recovered Territories ${ }^{14}$. Probably the widest range was the nationally-known surveillance code-

11 AINR, 0296/19, vol. 4, Pismo szefa PUBP w Gorzowie Wielkopolskim do kierownika Sekcji I Wydziału III WUBP w Poznaniu, 14 VIII 1948, p. 207; ibidem, Pismo dyrektora Departamentu III MBP do naczelnika Wydziału III WUBP we Wrocławiu, 23 IX 1948, p. 28.

12 AINR Po, 0038/27, Vol. 17, Pismo szefa WUBP w Zielonej Górze do szefa PUBP w Żaganiu, 12 IX 1951, p. 32.

13 And so, on the territory of the Strzelce county (Poznan region) thanks to the use of the agent pseud. "Siekiera" the identity of inspirator of returns from Dobiegniew was found. In June 1948, he left without permission for Hańczowa in the Gorlice county (Rzeszów region) where he contacted the GRN president in Ujście Gorlickie, who promised to support the efforts of the applicants to return. The news spread quickly among other displaced people( $i b i$ dem, Pismo naczelnika Wydziału III WUBP w Poznaniu do dyrektora Departamentu III MBP w Warszawie, 28 X 1948, c. 71).

${ }^{14}$ They referred in the case to, the instruction of the leadership of the OUN in Poland, issued in the summer of 1947 , ordering the Ukrainian conspirators to go to families in the Western Lands and start there construction of a limited and compact organizational network (J. Syrnyk, Ludność ukraińska na Dolnym Śląsku (1945-1989), Wrocław 2007, p. 75). do władz starościńskich, wojewódzkich, Urzędu Rady Ministrów i kancelarii prezydenta RP. Weryfikowali zarówno samych nadawców listów (przynależność do określonej kategorii wysiedleńców, ewentualne materiały kompromitujące lub działalność agenturalna na rzecz UB, związki z podziemiem, karalność, $\mathrm{w}$ tym pobyt $\mathrm{w}$ Centralnym Obozie Pracy w Jaworznie), jak i treść przesyłek (wiarygodność deklarowanych przyczyn niezadowolenia). W niektórych przypadkach sugerowano lokalnym władzom administracyjnym udzielenie pomocy materialnej petentom ${ }^{11}$. $\mathrm{O}$ aprobacie bądź odrzuceniu wniosku o powrót do województw wschodnich decydował wyłącznie Departament III MBP ${ }^{12}$. Równocześnie rozpoczęto poszukiwania tzw. inspiratorów nastrojów wyjazdowych oraz osób podejmujących się sporządzania listów w imieniu przesiedleńców, którzy często słabo władali w piśmie językiem polskim ${ }^{13}$.

Z chwilą stabilizacji osadnictwa ukraińskiego pierwszoplanowego znaczenia

11 AIPN, 0296/19, t. 4, Pismo szefa PUBP w Gorzowie Wielkopolskim do kierownika Sekcji I Wydziału III WUBP w Poznaniu, 14 VIII 1948, k. 207; ibidem, Pismo dyrektora Departamentu III MBP do naczelnika Wydziału III WUBP we Wrocławiu, 23 IX 1948, k. 28.

12 AIPN Po, 0038/27, t. 17, Pismo szefa WUBP w Zielonej Górze do szefa PUBP w Żaganiu, 12 IX 1951, k. 32

13 I tak na terenie powiatu strzeleckiego (województwo poznańskie) dzięki wykorzystaniu agenta ps. „Siekiera” ustalono tożsamość inspiratora powrotów z Dobiegniewa. Ten w czerwcu 1948 r. samowolnie wyjechał do Hańczowej w powiecie gorlickim (województwo rzeszowskie), gdzie skontaktował się z przewodniczącym GRN w Ujściu Gorlickim, który obiecał wesprzeć starania ubiegających się o powrót. Wieść błyskawicznie rozeszła się wśród innych przesiedleńców (ibidem, Pismo naczelnika Wydziału III WUBP w Poznaniu do dyrektora Departamentu III MBP w Warszawie, 28 X 1948, k. 71). 
name "Adventists", whose goal was to capture people who were recently associated with the III District of OUN ${ }^{15}$. Detainees were charged with belonging to (or cooperation with) a nationalist underground, involvement in the extermination of the Polish population and committing sabotage. Preliminary information on the underground structures and partisans known from the previous or present residence was obtained through the interrogations. Further valuable data (so-called compromising material) were obtained from UB cells from other administrative units. Data on a single surveilled person was collected under the so-called evidence act, which was included in the file of surveillance of the Ukrainian population residing in the given county ${ }^{16}$. Unfortunately, information on the scale of Ukrainians' arrests in the western part of the Poznan province between 1947 and 1949 has not been found yet. In the neighboring Wrockaw province, at least 83 people were arrested, including in the "Lubuskie" counties: Kożuchów 2, Szprotawa 1 and Żagań $1^{17}$.

In mid-1949 the leadership of the Department III of MBP reorganized the in-

15 By the end of 1948,21 of the 71 conspirators had fallen into the hands of UB officers. Among the arrested there were Mirosław Onyszkiewicz, one of the leading activists of the Ukrainian underground (AINR, 00231/131, Vol. 4, Raport o częściowej realizacji członków organizacji OUN-UPA przechodzących w agenturalnym opracowaniu Sekcji I Wydziału I Departamentu III MBP pod kryptonimem "Adwentyści" w okresie od 2 III 1948 r. do chwili obecnej, 2 XI 1948, c. 49).

16 AINR Sz, 0103/25, Raport dekadowy kierownika PUBP w Kołobrzegu za okres 15 IX-5 X 1947, pp. 141-142; ibidem, Raport dekadowy kierownika PUBP w Kołobrzegu za okres 5 VIII-15 VIII 1947, p. 118.

17 J. Syrnyk, Ludność ukraińska..., pp. 91-92. nabrała akcja odnalezienia i aresztowania ukrywających się na tzw. Ziemiach Odzyskanych byłych żołnierzy Ukraińskiej Powstańczej Armii (UPA) i działaczy Organizacji Ukraińskich Nacjonalistów (OUN) ${ }^{14}$. Prawdopodobnie największy zasięg miało prowadzone w skali krajowej rozpracowanie o kryptonimie „Adwentyści”, którego celem było schwytanie osób do niedawna związanych z Okręgiem III OUN ${ }^{15}$. Zatrzymanym stawiano zarzuty: przynależności do nacjonalistycznego podziemia (lub współpracy z nim), udziału w eksterminacji ludności polskiej i popełniania aktów sabotażu. Drogą przesłuchań uzyskiwano wstępne informacje na temat struktur konspiracyjnych i partyzantów znanych z poprzedniego bądź obecnego miejsca zamieszkania. Kolejne cenne dane (tzw. materiały kompromitujące) uzyskiwano od komórek UB z innych jednostek administracyjnych. Dane dotyczące pojedynczej inwigilowanej osoby gromadzono w ramach tzw. aktu ewidencyjnego, który włączano do teczki rozpracowania ludności ukraińskiej zamieszkują-

14 Powoływano się w tym przypadku na wydaną latem 1947 r. instrukcję kierownictwa OUN w Polsce, nakazującą ukraińskim konspiratorom udać się do rodzin na Ziemie Zachodnie i rozpocząć tam budowę ograniczonej i zwartej siatki organizacyjnej (J. Syrnyk, Ludność ukraińska na Dolnym Śląsku (1945-1989), Wrocław 2007, s. 75).

15 Do końca 1948 r. w ręce funkcjonariuszy UB wpadło 21 na ogółem 71 poszukiwanych konspiratorów. Wśród aresztowanych był Mirosław Onyszkiewicz, jeden z czołowych działaczy ukraińskiego podziemia (AIPN, 00231/131, t. 4, Raport o częściowej realizacji członków organizacji OUN-UPA przechodzących w agenturalnym opracowaniu Sekcji I Wydziału I Departamentu III MBP pod kryptonimem „Adwentyści” w okresie od 2 III 1948 r. do chwili obecnej, 2 XI 1948, k. 49). 
vigilation of the Ukrainian minority in Poland. Its aim was to "identify and detect nationalist elements that carry out espionage and diversionary and organizational work". The past work of the county UBP points "on the lines of the problem of fighting the OUN-UPA" was considered insufficient, neglected and largely unscheduled. In addition to recruiting agents with reduced operational capabilities, subordinate officers were accused of underestimating the issue and neglecting it. This allegedly led to the "activation of the diversionary, espionage and organizational work" by the OUN. As a result, the field security apparatus was obliged to draw up a list of persons suspected of belonging to and cooperating with the Bandera's underground "which will record the total number of nationalist criminals practicing in the area concerned, i.e. in their localities and places of work". In addition, it was recommended to check the Ukrainian intelligentsia, who came to the area of a specific administrative unit within the operation "W" and beyond. It was suggested that until recently, it had been the recruiting base of the Melnyk's OUN faction. People who were repatriated to Poland from the Anglo-Saxon occupancy zone in Germany who claimed to be Poles used German IDs (Kenkarte) issued in the former Galician District. It was suggested that the graduates of diversionary and sabotage schools sent to Poland could be found among them. These categories of suspects were divided into three basic groups, corresponding to the organizational structures of the OUN and UPA in postwar Poland. The Ukrainians from the Rzeszów province (counties: cej dany powiat ${ }^{16}$. Niestety, jak dotąd nie udało się znaleźć informacji obrazujących skalę aresztowań Ukraińców w zachodniej części województwa poznańskiego w latach 1947-1949. W sąsiednim województwie wrocławskim aresztowano co najmniej 83 osoby, z tego w "lubuskich” powiatach: kożuchowskim 2, szprotawskim 1 i żagańskim $1^{17}$.

W połowie 1949 r. kierownictwo Departamentu III MBP zreorganizowało rozpracowanie mniejszości ukraińskiej w Polsce. Jego celem miało być „ustalenie i wykrycie elementów nacjonalistycznych prowadzących robotę szpiegowsko-dywersyjną i organizacyjną". Dotychczasową pracę powiatowych UBP „po linii zagadnienia walki z OUN-UPA" uznano za niedostateczną, zaniedbaną i w dużej mierze bezplanową. Prócz werbowania agentury o ograniczonych możliwościach operacyjnych zarzucano podległym funkcjonariuszom niedocenianie ważności zagadnienia i jego zaniedbywanie. Jakoby doprowadziło to do „uaktywnienia roboty dywersyjno-szpiegowskiej i organizacyjnej" ze strony OUN. W związku z tym terenowy aparat bezpieczeństwa zobowiązano do sporządzenia wykazu osób podejrzanych o przynależność i współpracę z podziemiem banderowskim, „dzięki któremu zostanie ujęty na ewidencję ogół przestępców nacjonalistycznych uprawiających swą działalność na danym terenie, tzn. w miejscowościach swego zamieszkania, miejscach pracy". Po-

16 AIPN Sz, 0103/25, Raport dekadowy kierownika PUBP w Kołobrzegu za okres 15 IX-5 X 1947, k. 141-142; ibidem, Raport dekadowy kierownika PUBP w Kołobrzegu za okres 5 VIII-15 VIII 1947, k. 118.

17 J. Syrnyk, Ludność ukraińska..., s. 91-92. 
Przemyśl, Brzozów, Lesko, Sanock, Gorlice) and Cracow province (Nowy Sącz county), which were the region of action of the First District of the OUN, were to be included in the first group. In turn, the second group were the people displaced from the area of the Second District of the OUN, i.e. the counties of Jarosław, Lubaczów and partially Przemyśl (Rzeszów province) and a fragment of Tomaszów county (Lublin province). Finally, the last, third category was formed by the Ukrainians from the Lublin province, from Hrubieszów county and partly from the counties of Tomaszów, Włodawa and BielskoPodlaskie, belonging to the Third District of the OUN.

Such a schema will give an image of the placement of nationalist elements in your area, showing their organizational affiliation and depict the ratio of the intensity of the Ukrainian population to the number of people suspected of belonging to the OUN-UPA and cooperation with that organization from individual OUN districts and the state of the agency in this environment

- explained WUBP chief in Wrocław. The divided groups of Ukrainian displaced people were subject to surveillance whether they belonged to the underground or cooperated with the help of available agents. Materials on "figurants", i.e., those who were "invigilated", runing "hostile activities" were to be deposited in the so-called files of the agent work, where their former organizational affiliation would be emphasized. It was hoped that the adoption of this type of operational scenario would help to deconstruct and completely eliminate the nadto polecono zewidencjonować inteligencję ukraińską, która przybyła na teren określonej jednostki administracyjnej w ramach akcji „W” i poza nią. Sugerowano, że do niedawna była ona zapleczem rekrutacyjnym melnykowskiej frakcji OUN. Za grupę wymagającą szczególnego nadzoru uznano też osoby repatriowane do kraju $\mathrm{z}$ anglosaskich stref okupacyjnych w Niemczech, które podając się za Polaków, legitymowały się kenkartami wystawionymi w dawnym Dystrykcie Galicja. Sugerowano, że wśród nich mogli znaleźć się przerzucani do kraju absolwenci szkół dywersyjno-sabotażowych. Wymienione kategorie podejrzanych polecono podzielić na trzy zasadnicze grupy, odpowiadające strukturom organizacyjnym OUN i UPA w powojennej Polsce. Do pierwszej grupy mieli być zaliczeni Ukraińcy pochodzący z terenu województw rzeszowskiego (powiaty: przemyski, brzozowski, leski, sanocki, gorlicki) i krakowskiego (powiat nowosądecki), będących rejonem działania I Okręgu OUN. Z kolei do grupy drugiej osoby przesiedlone $\mathrm{z}$ obszaru Okręgu II OUN, czyli powiatów jarosławskiego, lubaczowskiego i częściowo przemyskiego (województwo rzeszowskie) oraz fragmentu powiatu tomaszowskiego (województwo lubelskie). Wreszcie ostatnią, trzecią kategorię tworzyli Ukraińcy z Lubelszczyzny, z powiatu hrubieszowskiego i częściowo powiatów: tomaszowskiego, włodawskiego i bielsko-podlaskiego, należących do Okręgu III OUN.

Tak sporządzony schemat da obraz rozmieszczenia elementów nacjonalistycznych na 
remnants of Ukrainian nationalist organizations in Poland ${ }^{18}$.

At the same time, the surveillance of the Ukrainians was also included in the duties of the MBP counterintelligence. In June 1949, Sections I of the Divisions I of the UBP Province Offices launched a comprehensive invigilation (classified as object ones $^{19}$ ) with the symbol RO-3 on "white emigration", Belarusians, Ukrainians, Lithuanians and other nationalities "privileged during the German occupation" ${ }^{20}$. The security officers were interested in people of Ukrainian nationality (they were described with exaggeration as "nationalists"), who came to the territory outside of the "Vistula" operation. Most of them were representatives of the former political and economic migrants who during the war belonged to social organizations, police and military formations tolerated or appointed by the German authorities. They were considered potential agents of Western intelligence services, "the base for hostile activity against the USSR and People's Republic of Poland"21.

In the first four years of the existence of the Zielona Góra province (founded in June 1950), the surveillance of local Ukrainians was primarily the task of the

18 AINR Po, 0038/27, 15, Pismo szefa WUBP we Wrocławiu do szefa PUBP w Żaganiu, 14 VIII 1949 , c. $22-25$.

19 On the terminology of security apparatus and classification of operational affairs, see: F. Musiał, Podręcznik bezpieki. Teoria pracy operacyjnej Stużby Bezpieczeństwa $w$ świetle wydawnictw resortowych Ministerstwa Spraw Wewnętrznych PRL (19701989), Kraków 2007.

20 AINR Po, 003/261, Raport o wszczęciu rozpracowania obiektowego RO-3, 21 VI 1949, pp. 266-281.

21 Ibidem, Raport o przebiegu rozpracowania obiektowego RO-3, 20 VIII 1949, p. 16.
Waszym terenie z uwidocznieniem ich przynależności organizacyjnej i zobrazuje stosunek nasilenia ludności ukraińskiej do ilości osób podejrzanych o przynależność do OUN-UPA i współpracę z tą organizacją z poszczególnych okręgów OUN i stan agentury tkwiącej w tym środowisku

- wyjaśniał szef WUBP we Wrocławiu. Podzielone grupy przesiedleńców ukraińskich należało rozpracowywać pod kątem ich przynależności do podziemia lub współpracy z nim za pomocą dostępnej agentury. Materiały dotyczące „figurantów", czyli osób inwigilowanych, prowadzących „wrogą działalność”, miały być składane w tzw. teczkach agenturalnego opracowania, gdzie podkreślano ich dawną przynależność organizacyjną. Wyrażano nadzieję, że przyjęcie tego rodzaju scenariusza działań operacyjnych przyczyni się do rozszyfrowania i całkowitej likwidacji resztek ukraińskich organizacji nacjonalistycznych w Polsce ${ }^{18}$.

W podobnym czasie inwigilacja Ukraińców weszła także w zakres obowiązków kontrwywiadu MBP. W czerwcu 1949 r. Sekcje I Wydziałów I Wojewódzkich UBP wszczęly kompleksowe rozpracowanie (klasyfikowane jako obiektowe ${ }^{19}$ ) oznaczone symbolem RO-3, dotyczące „białej emigracji”, Białorusinów, Ukraińców, Litwinów i innych narodowości , uprzywile-

18 AIPN Po, 0038/27, 15, Pismo szefa WUBP we Wrocławiu do szefa PUBP w Żaganiu, 14 VIII 1949, k. 22-25.

${ }^{19} \mathrm{Na}$ temat terminologii aparatu bezpieczeństwa oraz klasyfikacji spraw operacyjnych zob. F. Musiał, Podręcznik bezpieki. Teoria pracy operacyjnej Służby Bezpieczeństwa $w$ świetle wydawnictw resortowych Ministerstwa Spraw Wewnętrznych PRL (1970-1989), Kraków 2007. 
officers of Section II of the Division III of WUBP in Zielona Góra and their guiding staff of the sections III in the county UBPs. Section II of the Division III of WUBP in Wroclaw sent 3 issues of agency (among others the one of Fr. Włodzimierz Hajdukiewicz), 6 cases of registration and 5 (county) observation files (the equivalent of later object investigation) to Zielona Góra ${ }^{22}$. Several months later, most of the operational materials obtained during the surveillance of Ukrainians in the Zielona Góra province were concentrated in object investigation " $Ł e w a d a$ ” founded by Section II of the Division III of WUBP in Zielona Góra "for a group of members and associates of OUN-UPA". It covered, as suggested in March 1952, 186 people. However, a summary of county surveillances with the same codename would indicate that up to 500 people were resettled from the Podkarpacie province and "repatriated" from eastern Galicia. In counties not included in the settlement under the "Vistula" operation control was supposed over all identified Ukrainians who hid their identities. For example, PUBP in Gubin included in the operational evidence 92 people from the Tarnów province who were suspected of belonging to the SS "Galizien" or the underground. In the whole province in March 1952 they listed a total of 47 personal sources of information penetrating the Ukrainian environment, with the highest in the county shooting 13 informants

22 AINR Wr, 053/618/1, Akt zdawczo-odbiorczy materiałów przekazywanych przez Wydział III WUBP we Wrocławiu Wydziałowi III WUBP w Zielonej Górze, 18 VIII 1950, c. 91. jowanych w czasie okupacji niemieckiej"20. Interesowano się osobami narodowości ukraińskiej (na wyrost określano je mianem „nacjonalistów”), które znalazły się na danym terenie poza akcją „Wisła”. W większości byli to przedstawiciele dawnych migracji politycznych i zarobkowych, którzy w czasie wojny należeli do organizacji społecznych, formacji policyjnych i wojskowych tolerowanych, bądź powołanych przez władze niemieckie. Uważano ich za potencjalną agenturę zachodnich służb wywiadowczych, „,bazę do wrogiej działalności przeciwko ZSRR i Polsce Ludowej”21.

W pierwszych czterech latach istnienia województwa zielonogórskiego (powstało w czerwcu 1950 r.) rozpracowanie miejscowych Ukraińców było przede wszystkim zadaniem funkcjonariuszy Sekcji II Wydziału III WUBP w Zielonej Górze oraz realizujących ich wytyczne pracowników referatów III w powiatowych UBP. Sekcja II Wydziału III WUBP we Wrocławiu przekazała swemu odpowiednikowi w Zielonej Górze 3 sprawy agencyjne (m.in. dotyczącą ks. Włodzimierza Hajdukiewicza), 6 spraw ewidencyjnych i 5 (powiatowych) teczek obserwacyjnych (odpowiednik późniejszych rozpracowań obiektowych) ${ }^{22}$. Kilkanaście miesięcy później większość materiałów operacyjnych uzyskanych w trakcie inwigilacji Ukraińców w Zielonogórskiem skoncentrowano w rozpracowaniu obiek-

20 AIPN Po, 003/261, Raport o wszczęciu rozpracowania obiektowego RO-3, 21 VI 1949, k. 266-281.

21 Ibidem, Raport o przebiegu rozpracowania obiektowego RO-3, 20 VIII 1949, k. 16.

22 AIPN Wr, 053/618/1, Akt zdawczo-odbiorczy materiałów przekazywanych przez Wydział III WUBP we Wrocławiu Wydziałowi III WUBP w Zielonej Górze, 18 VIII 1950, k. 91. 
and 1 resident ${ }^{23}$. Section II of Division III of WUBP initiated the search for 11 people (including Michał Fesz "Roháče" and Iwan Smarż "Pimsta"), whose relatives and friends lived in the Zielona Góra province $^{24}$. Until 1954 they started probably several dozens of operational cases concerning Ukrainians. In this framework, they invigilated (or searched for) over six hundred people accused of: ties with underground ${ }^{25}$, and contacts with emigration couriers (local variants of the operations "C-1" codename [targeted against OUN-B and British Intelligence] $]^{26}$, "Pająki” [OUN-

23 AINR, 0296/16/5, Pismo por. Aleksandra Kosmołowicza, p.o. naczelnika Wydziału III WUBP w Zielonej Górze do naczelnika Wydziału II Departamentu III MBP, 22 III 1952, 83; ibidem, Relacja z rozpracowania obiektowego krypt. "Łewada" w PUBP w Gubinie, 17 III1952, c. 110; ibidem, Relacja z rozpracowania obiektowego krypt. "Łewada" w PUBP w Strzelcach Krajeńskich, 17 III 1952, c. 108.

24 Ibidem, Wykaz nr 1 figurantów i członków organizacji OUN-UPA ukrywających się na terenie województwa zielonogórskiego aktywnie poszukiwanych 18 IX 1952, c. 121-124.

25 In the first months of 1953, over 40 Ukrainian conspirators from the counties of Przemyśl (Tarnopol province), Bielsk-Podlaski and Włodawa (ibidem, Pismo zastępcy szefa WUBP w Zielonej Górze do szefów PUBP, 1953, c. 65; ibidem, Pismo naczelnika Wydziału III WUBP w Lublinie do naczelnika Wydziału III WUBP w Zielonej Górze, 26 III 1953, c. 111).

26 The main character in the operation " $\mathrm{C}-1$ " was Leon Lapinski "Zenon" - until 1947 a deputy of the Security Service in the III District of the OUN, arrested by the Czechoslovak authorities, transferred to the Polish side and recruited by MBP under the pseud. "Boguslaw". In the autumn of 1948 the provocateur contacted the last armed unit operating in the Lublin region. He urged his members to leave the hiding place and continue their underground activities. Thus, the core of the "underground" organization was formed, which in the coming years co-operated with several dozen unconscious threats of Ukrainians (only partially former UPA and OUN members) resettled to the Western and Northern Lands. After establishing contact with the Bandera's towym „Łewada” założonym przez Sekcję II Wydziału III WUBP w Zielonej Górze „na grupę członków i współpracowników OUN-UPA”. Objęło ono, jak sugerowano w marcu 1952 r., 186 osób. Jednak podsumowanie powiatowych rozpracowań o tym samym kryptonimie wskazywałoby na plany inwigilacji aż 500 osób, przesiedlonych z Podkarpacia i „repatriowanych” z Galicji Wschodniej. W powiatach nieobjętych osadnictwem w ramach akcji „Wisła” miała być to zapewne kontrola wszystkich zidentyfikowanych Ukraińców, którzy ukrywali swoją tożsamość. Na przykład PUBP w Gubinie do ewidencji operacyjnej włączył 92 osoby pochodzące przeważnie $\mathrm{z}$ województwa tarnopolskiego, podejrzane o przynależność do SS „Galizien” lub podziemia. W całym województwie w marcu 1952 r. wykazano w sumie 47 osobowych źródeł informacji penetrujących środowisko ukraińskie, $\mathrm{z}$ tego najwięcej $\mathrm{w}$ powiecie strzeleckim: 13 informatorów i 1 rezydenta ${ }^{23}$. Sekcja II Wydziału III WUBP wszczęła poszukiwania 11 osób (w tym Michała Fesza „Rohacza” i Iwana Smarża „Pimstę”), których krewni i znajomi mieszkali w Zielonogórskiem $^{24}$. Do 1954 r. założono prawdopodobnie kilkadziesiąt spraw operacyjnych

23 AIPN, 0296/16/5, Pismo por. Aleksandra Kosmołowicza, p.o. naczelnika Wydziału III WUBP w Zielonej Górze do naczelnika Wydziału II Departamentu III MBP, 22 III 1952, 83; ibidem, Relacja z rozpracowania obiektowego krypt. „Łewada” w PUBP w Gubinie, 17 III 1952, k. 110; ibidem, Relacja z rozpracowania obiektowego krypt. „Łewada” w PUBP w Strzelcach Krajeńskich, 17 III 1952, k. 108.

24 Ibidem, Wykaz nr 1 figurantów i członków organizacji OUN-UPA ukrywających się na terenie województwa zielonogórskiego aktywnie poszukiwanych 18 IX 1952, k. 121-124. 


\section{M and the US secret services] ${ }^{27}$ and "Raki"}

emigrants and underground cells in Ukraine, MBP decided in January 1950 to formally commence operation "C-1". The security forces of the USSR and Czechoslovakia, which cooperated with the Polish security forces, controlled courier routes, which, depending on current needs, were opened or blocked by arresting unaware emissaries. In general efforts were made to make the "Zenon/Boguslaw's" "net" the most important "bridge" between the West and the USRR conspiracy. Increasingly, the "mishaps" of courier groups and the arrest of individual conspirators in the country provoked suspicion in Łapinski's circles in the Ukrainian community. In this situation MBP decided to end the operation. In April 1954 people were involved in the operation arrested (86 in total), and the identity of the agent was protected. " $\mathrm{C}-1$ " was one of the largest operations carried out in the first postwar years by the communist security forces against the Ukrainian independence movement. For four years, couriers from the West led to the USRR, and back, the OUN emigration was infiltrated, and it paralyzed its efforts to influence the situation in Ukraine. It effectively counteracted all the activities organized by the Western special services. The publication in the communist media of the end of the operation compromised British intelligence and contributed to further OUN divisions. (See more: I. Hałagida, Prowokacja "Zenona. Gene$z a$, przebieg i skutki operacji MBP o kryptonimie „C1 "przeciwko banderowskiej frakcji OUN $i$ wywiadowi brytyjskiemu (1950-1954), Warszawa 2005, passim). In June 1952, in the area of the Nowy Sól county, department III of WUBP in Zielona Góra liquidated a group of 5 "Ukrainian nationalists" who, after the disarmament of the Polish Army officer, were planning to flee abroad. The organizer of this group was Jan (Iwan) Kopczak ps. "Sosna", member of the Foreign Corps of the OUN, radio interviewer trained by British intelligence, AINR Po, 060/45/46, Analiza działalności grup bandyckich i nielegalnych organizacji na terenie województwa zielonogórskiego za rok 1952 i miesiace styczeń-marzec 1953, 10 IV 1953, c. 2. Kopczak was arrested in March 1953 in Tczew. Shortly thereafter he died of suicide in Warsaw during the interrogation (I. Hałagida, $o p$. cit., pp. 212-214).

27 The operation against the OUN-M began in 1949 , with the arrest of Melnyk's emissary Wlodzimierz Fenyk "Karyj". Leading agents in the operation were: "Adam", "Bolesław" and "Jarosz". The main purpose of the activities was disinformation with the help of correspondence, radio and couriers. The OUN-M management structures were successfully infiltrated. In 1955, one of the agents was introduced dotyczących Ukraińców. W ich ramach inwigilowano (lub poszukiwano) przeszło sześćset osób, którym zarzucano: związki z podziemiem ${ }^{25}$, kontakty z kurierami emigracyjnymi (lokalne warianty operacji o kryptonimach „C-1” [wymierzonej w OUN-B i wywiad brytyjski] ${ }^{26}$, „Pają-

${ }^{25} \mathrm{~W}$ pierwszych miesiącach 1953 r. poszukiwano przeszło 40 ukraińskich konspiratorów pochodzących z powiatów przemyślańskiego (województwo tarnopolskie), bielsko-podlaskiego i włodawskiego (ibidem, Pismo zastepcy szefa WUBP w Zielonej Górze do szefów PUBP, 1953, k. 65; ibi$d e m$, Pismo naczelnika Wydziału III WUBP w Lublinie do naczelnika Wydziału III WUBP w Zielonej Górze, 26 III 1953, k. 111).

${ }^{26}$ Główną postacią w operacji „C-1” był Leon Łapiński „Zenon” - do 1947 r. referent Służby Bezpieczeństwa w III Okręgu OUN, aresztowany przez władze czechosłowackie, przekazany stronie polskiej i zwerbowany przez MBP pod ps. „Bogusław”. Jesienią 1948 r. prowokator skontaktował się z ostatnim zbrojnym oddziałem działającym na Lubelszczyźnie. Skłonił jego członków do opuszczenia dotychczasowej kryjówki i kontynuowania konspiracyjnej działalności. Tak powstał trzon „podziemnej” organizacji, z którą w najbliższych latach współdziałało kilkudziesięciu nieświadomych zagrożenia Ukraińców (tylko częściowo b. upowców i ouenowców) przesiedlonych na Ziemie Zachodnie i Północne. Po nawiązaniu kontaktów z banderowską emigracją i ogniwami podziemia na Ukrainie MBP w styczniu $1950 \mathrm{r}$. podjęło decyzję o formalnym rozpoczęciu operacji „C-1”. Współdziałające z polską „,bezpieką" organy bezpieczeństwa ZSRR i Czechosłowacji kontrolowały szlaki kurierskie, które, w zależności od bieżących potrzeb, otwierano lub blokowano, aresztując nieświadomych emisariuszy. Ogólnie czyniono starania, by „siatka” „Zenona/Bogusława” stała się najważniejszym „pomostem” między Zachodem a konspiracją w USRR. Coraz częstsze „wpadki” grup kurierskich i aresztowania pojedynczych konspiratorów w kraju wywołały w środowiskach ukraińskich podejrzliwość wobec Łapińskiego. W tej sytuacji MBP zadecydowało o zakończeniu operacji. W kwietniu 1954 r. rozpoczęto aresztowania osób (łącznie 86) wplątanych w operację, umiejętnie przy tym chroniono tożsamość agentury. „C-1” była jedną $\mathrm{z}$ największych operacji prowadzonych w pierwszych latach powojennych przez komunistyczne organy bezpieczeństwa wobec ukraińskiego ruchu niepodległościowego. Przez cztery lata kontrolowano kurierskie szlaki ZCz OUN wiodące z Zachodu do 
[called Ukrainian National Guard and British intelligence ${ }^{28}$ ), belonging to the old "nationalist" political and social organizations ${ }^{29}$, or working alongside the German police and military formations, the

there. Operational activities on this subject were conducted until 1962 (see more: M. Majewski, Teodor Dak i operacja "Pajaki", [in:] Stużby bezpieczeństwa Polski i Czechostowacji wobec Ukraińców, edit. G. Motyka, Warszawa 2005, pp. 206-247).

${ }^{28}$ In July 1951, at the request of the Ukrainian National Guard (Ukrajinśka Nacionalalna Hwardia, UNH) Klem Remeszyło vel Zygmunt Dziwowski came to Poland. He was supposed to verify the activity of previously dispatched couriers, as well as create transfer points and exchange of secret correspondence. After a two-week stay in Poland Remeszyło returned to Germany, which was "hoodwink" allowed him MBP officers. In December 1951, he again came to the People's Republic of Poland, bringing with him materials for the preparation of the journal and organizational instructions. He passed through the transport point in Zasieki in Zielona Góra province which was controlled by the Department I of MBP in Zielona Góra. As a result of the carelessness of the officers, he realized that he was being watched, which prompted the "security" to decide to arrest the stranger in Katowice and transfer him to the Warsaw headquarters. While in custody at the request of the UB staff, he handed over his possessions to Agent Zaremba (Jakub Paluch) and corresponded with UNH. In April 1952, performing an operational task, he attempted to flee the country. After his arrest in Żagań, he was handed over to the Soviet authorities (AINR, 00231/131/23, Notatka informacyjna dotycząca agenturalnego rozpracowania krypt. "Raki" wg stanu na dzień 30 VI 1954, 30 VI 1954, c. 108-111). In October 1952, through the GDR territory, he got to Lubsk and from there to Zielona Góra, Wasyl Korol - another UNH courier. After a short stay in Szczecin, he was arrested on 8 October in Świecie county in Bydgoszcz province (AINR, 00231/223/46, Streszczenie sprawy aresztowanego kuriera UNH, figuranta agenturalnego rozpracowania "Raki" Korola Wasyla vel Kubickiego Wacława, 28 III 1953, c. 28-35).

${ }^{29}$ In March 1953, at the request of the WUBP in Poznan, Ukrainian pre-war students of the Poznan University, associated with corporation "Czarnomore" and organization "Hromada" (AINR Po, 003/261, Pismo naczelnika Wydziału III WUBP w Poznaniu do naczelnika Wydziału III WUBP w Zielonej Górze, 25 V 1953, c. 131-132). ki” [OUN-M i służby specjalne USA $]^{27}$ i „Raki” [tzw. Ukraińska Gwardia Narodowa i wywiad brytyjski $]^{28}$ ), przynależność

USRR i z powrotem, infiltrowano ouenowską emigrację i paraliżowano jej próby oddziaływania na sytuację na Ukrainie. Efektywnie też przeciwdziałano wszelkim przedsięwzięciom organizowanym przez zachodnie służby specjalne. Opublikowanie w komunistycznych środkach masowego przekazu informacji na temat zakończonej operacji skompromitowało wywiad brytyjski, a także przyczyniło się do kolejnych rozłamów w OUN (zob. szerzej I. Hałagida, Prowokacja „Zenona. Geneza, przebieg i skutki operacji MBP o kryptonimie „C-1" przeciwko banderowskiej frakcji OUN $i$ wywiadowi brytyjskiemu (1950-1954), Warszawa 2005, passim). W czerwcu 1952 r. na terenie powiatu nowosolskiego Wydział III WUBP w Zielonej Górze zlikwidował grupę 5 „nacjonalistów ukraińskich”, którzy po rozbrojeniu oficera WP zamierzali zbiec za granice. Za organizatora wymienionej grupy uchodził Jan (Iwan) Kopczak ps. „Sosna”, członek Zagranicznych Formacji OUN, radiotelegrafista przeszkolony przez wywiad brytyjski AIPN Po, 060/45/46, Analiza działalności grup bandyckich i nielegalnych organizacji na terenie województwa zielonogórskiego za rok 1952 i miesiące styczeń-marzec 1953, 10 IV 1953, k. 2. Kopczak został aresztowany w marcu $1953 \mathrm{r}$. w Tczewie. Wkrótce potem zginą śmiercią samobójczą w Warszawie w trakcie przesłuchania (I. Halagida, op. cit., s. 212-214).

27 Operację przeciwko OUN-M rozpoczęto w 1949 r. wraz z aresztowaniem emisariusza melnykowskiego Włodzimierza Fenyka ps. „Karyj”. Czołową rolę w działaniach operacyjnych odegrali agenci o pseudonimach: „Adam”, „Bolesław” i „Jarosz”. Podstawowym celem działań była dezinformacja za pomocą korespondencji, łączności radiowej i kurierskiej. Z powodzeniem infiltrowano struktury kierownicze OUN-M. W 1955 r. wprowadzono tam jednego z agentów. Działania operacyjne w tej sprawie prowadzono aż do 1962 r. (zob. szerzej M. Majewski, Teodor Dak i operacja „Pająki”, [w:] Stużby bezpieczeństwa Polski i Czechosłowacji wobec Ukrainców, red. G. Motyka, Warszawa 2005, s. 206-247).

${ }^{28}$ W lipcu 1951 r. z polecenia Ukraińskiej Gwardii Narodowej (Ukrajinśka Nacjonalna Hwardia, UNH) przybył do Polski Kłym Remeszyło vel Zygmunt Wysłowski, który miał zweryfikować działalność wcześniej wysłanych kurierów, a także stworzyć punkty przerzutowe i wymiany tajnej korespondencji. Po dwutygodniowym pobycie w Polsce Remeszyło wrócił do Niemiec, na co „kapturowo” zezwolili mu funkcjonariusze MBP. W grudniu $1951 \mathrm{r}$. 
murder of Poles and Jews, "denning" of weapons in former places of residence and foreign currency trade. Besides police supervision included sowers of "hostile propaganda" (especially the so-called war psychosis), alleged perpetrators of diversionary and sabotage works ${ }^{30}$, participants in the "suspicious meetings", farmers hindering compulsory purchase of crops, people corresponding with relatives abroad and rejecting a proposal of cooperation with "security"31. Subsequent object-oriented, environmental and introductory-agency invigilation, which in the years 19511953 were established by both the Section II of the Division III of WUBP and Sections III of PUBPs, had mostly codenames "Łewada", "Łewada II" and "Łemko"32. This

30 Wasyl K., a tractor driver from PGR Lubicz (Strzelce Krajeńskie county) "committed a robbery of economic sabotage, [...] drove an empty seed drill on the field, as a result of which he did not sow about one hectare of land". In the course of the investigation, it was determined that the above person participated in listening to the "broadcast of imperialist states" (AINR Po, 060/45, vol. 8, Sprawozdanie z pracy Wydziału III WUBP w Zielonej Górze i podległych PUBP po linii Wydziału III za miesiąc kwiecień 1953 r., 8 V 1953 r., c. 81).

31 AINR Po, 060/65, vol. 3, Sprawozdanie dekadowe o przebiegu pracy po linii Sekcji I (zagadnienie "Dniestr") za okres od 25 XII do 25 I 1950, 24 I 1950, c. 7-8; AINR Po, 0038/27, vol. 12, Raport o wszczęciu rozpracowania obiektowego "Dniestr", 15 IX 1950, c. 1.

32 AINR Po, 060/65, vol. 5, Sprawozdanie okresowe o przebiegu pracy po linii Referatów III PUBP i Wydziału III WUBP za okres 1 V-31-V 1952, c. 37; AINR Po, 060/45, t. 8, Rozpracowania założone po linii Wydziału III - sprawozdanie za I kwartał 1953 r. , c. 61-62; ibidem, Sprawozdanie z pracy Wydziału III WUBP w Zielonej Górze i podległych PUBP po linii Wydziału III za miesiąc kwiecień 1953 r., 8 V 1953 r., c. 88. Alongside with "Łewada" i "Łemko" officers of Department III of the WUBP in Zielona Góra conducted the object-oriented work at that time: "Dywersant" (referring to the Bielsrus people), "Narodowiec" (Lithuanians), “Żuk" ("white emigration”), do dawnych "nacjonalistycznych” organizacji politycznych i społecznych ${ }^{29}$ lub działających u boku Niemców formacji policyjnych i wojskowych, mordowanie Polaków i Żydów, „melinowanie” broni w dawnych miejscach zamieszkania i handel obcą walutą. Prócz tego policyjnym nadzorem objęto siewców „wrogiej propagandy” (zwłaszcza tzw. psychozy wojennej), domniemanych sprawców robót dywersyjnych i sabotażowych ${ }^{30}$, uczestników „po-

ponownie przybył do PRL, przywożąc ze sobą materiały do sporządzania tajnopisów i instrukcje organizacyjne. Przechodził przez kontrolowany przez Departament I MBP punkt przerzutowy w Zasiekach w Zielonogórskiem. Wskutek nieostrożności funkcjonariuszy zorientował się, że jest obserwowany, co skłoniło „bezpiekę” do podjęcia decyzji o aresztowaniu przybysza w Katowicach i przekazaniu warszawskiej „centrali”. Przebywając w areszcie na polecenie pracowników UB, przekazał posiadane materiały agentowi „Zarembie” (Jakub Paluch) oraz korespondował z UNH. W kwietniu 1952 r. wykonując zadanie operacyjne, usiłował zbiec z kraju. Po aresztowaniu w Żaganiu został przekazany władzom radzieckim (AIPN, 00231/131/23, Notatka informacyjna dotycząca agenturalnego rozpracowania krypt. „Raki” wg stanu na dzień 30 VI 1954, 30 VI 1954, k. 108-111). W październiku 1952 r. kanałami przerzutowymi przez terytorium NRD dostał się do Lubska, a stamtąd do Zielonej Góry, Wasyl Korol - kolejny kurier UNH. Po krótkim pobycie w Szczecinie został aresztowany 8 października w powiecie świeckim w Bydgoskiem (AIPN, 00231/223/46, Streszczenie sprawy aresztowanego kuriera UNH, figuranta agenturalnego rozpracowania „Raki” Korola Wasyla vel Kubickiego Wacława, 28 III 1953, k. 28-35).

29 W marcu 1953 r. na polecenie WUBP w Poznaniu poszukiwano ukraińskich przedwojennych studentów Uniwersytetu Poznańskiego, związanych z korporacją „Czarnomore” i organizacją „Hromada" (AIPN Po, 003/261, Pismo naczelnika Wydziału III WUBP w Poznaniu do naczelnika Wydziału III WUBP w Zielonej Górze, 25 V 1953, k. 131-132).

30 Wasyl K., traktorzysta z PGR Lubicz (powiat Strzelce Krajeńskie) „dopuścił się roboty zakrawającej na sabotaż gospodarczy, [...] jeździł pustym siewnikiem po polu, w wyniku czego nie obsiał około jednego hektara ziemi”. W toku śledztwa ustalono, iż ww. brał udział w słuchaniu ,audycji państw imperialistycznych" (AIPN Po, 060/45, t. 8, Sprawoz- 
was a direct reference to the naming of the organizational structures of the Ukrainian underground ${ }^{33}$.

It seems that the apogee of engagement of the security apparatus and its agencies in the operational activities against the Ukrainians was in the first half of 1954. In February, Section II of the Department III of the WUBP in Zielona Gora, conducting four operational cases, was responsible for the surveillance of 134 persons. At the same time, UBP in counties controlled as many as 512 "figurants" in 18 object-oriented cases ${ }^{34}$. It was the time to finalize the C-1 operation on a national scale.

The intensification of operations against the Ukrainian people was a derivative of the growing rivalry between the "peace camp" and the block of western states, and the consequence of the acceptance by the People's Republic of Poland of the "intensification of class struggle as socialism progressed. Since 1948, not only the declared enemies of the system were repressed, but also entire social groups who were identified as potentially dangerous. As a result, thousands of Ukrainians in Poland came to the "register of criminal and suspected element" run by the "security", which in time covered about 6 mil-

"Wisła" (former activists National party), "Odra" (National Armed Forces) and "O" (AK and WiN).

${ }^{33}$ It is region "Łewada" in III District OUN and 26th Tactical Section "Lemko" belonging to VI Military District UPA “San" in Operational Group UPA-West.

34 AINR Po, 060/45, vol. 11, Stan rozpracowań po linii Sekcji II Wydziału III WUBP w Zielonej Górze na dzień 28 II 1954 r., 5 III 1954, c. 50. dejrzanych spotkań", rolników utrudniających przymusowy skup płodów rolnych, osoby korespondujące z krewnymi za granicą i odrzucające propozycję współpracy z „bezpieką" ${ }^{31}$. Kolejne rozpracowania obiektowe, środowiskowe i wstępno-agencyjne, które w latach 1951-1953 były zakładane zarówno przez Sekcję II Wydziału III WUBP, jak i Referaty III PUBP, nosiły najczęściej kryptonimy „Łewada”, „Łewada II” i „Łemko”32. Było to bezpośrednie odniesienie do nazewnictwa struktur organizacyjnych ukraińskiego podziemia ${ }^{33}$.

Wydaje się, że apogeum zaangażowania aparatu bezpieczeństwa i jego agentury w działania operacyjne wobec Ukraińców przypada na pierwszą połowę $1954 \mathrm{r}$. W lutym tego roku Sekcja II Wydziału III

danie z pracy Wydziału III WUBP w Zielonej Górze i podległych PUBP po linii Wydziału III za miesiąc kwiecień 1953 r., 8 V 1953 r., k. 81).

${ }^{31}$ AIPN Po, 060/65, t. 3, Sprawozdanie dekadowe o przebiegu pracy po linii Sekcji I (zagadnienie „Dniestr”) za okres od 25 XII do 25 I 1950, 24 I 1950, k. 7-8; AIPN Po, 0038/27, t. 12, Raport o wszczęciu rozpracowania obiektowego „Dniestr”, 15 IX 1950, k. 1.

32 AIPN Po, 060/65, t. 5, Sprawozdanie okresowe o przebiegu pracy po linii Referatów III PUBP i Wydziału III WUBP za okres 1 V-31 V 1952, k. 37; AIPN Po, 060/45, t. 8, Rozpracowania założone po linii Wydziału III - sprawozdanie za I kwartał 1953 r., k. 61-62; ibidem, Sprawozdanie z pracy Wydziału III WUBP w Zielonej Górze i podległych PUBP po linii Wydziału III za miesiąc kwiecień 1953 r., 8 V 1953 r., k. 88. Prócz spraw „Łewada” i „Łemko" funkcjonariusze Wydziału III WUBP w Zielonej Górze prowadzili w tym czasie rozpracowania obiektowe: „Dywersant” (dot. osób narodowości białoruskiej), „Narodowiec” (Litwini), „Żuk” („biała emigracja”), „Wisła” (dawni działacze Stronnictwa Narodowego), „Odra” (Narodowe Siły Zbrojne) i „O” (AK i WiN).

${ }^{33}$ Chodzi tu o Nadrejon „Łewada” w III Okręgu OUN i 26. Odcinek Taktyczny „Łemko” należący do VI Okręgu Wojskowego UPA „San” w Grupie Operacyjnej UPA-Zachód. 
lion names of Polish citizens ${ }^{35}$. The list of allegations against displaced Ukrainian in numerous reports was expanded year by year, skillfully matching their links with the underground, with alleged sabotage of the six-year plan ${ }^{36}$. Former members of the OUN and UPA were to hinder the action of collectivization of the villages in the eyes of political police workers ${ }^{37}$. There was also concern about the penetration of people who were ideologically insecure to administer and exploit their positions for actions contrary to the then political line of the authorities ${ }^{38}$.

In mid-1954 the actions of the central and provincial security apparatus in the Ukrainian environment were reorganized. By the end of this year, all previous cases concerning Ukrainians were taken over by counterintelligence officers from Divisiont X of the Department I of MBP. In the Zielona Góra province their guidelines were implemented by subordinates from Section X of the Division I of WUBP in Zielona Góra. Most likely, as a result of the gradual reduction of political police personnel in October 1954, a review of the current work on "Ukrainian nationalists suspected of organizational activity

35 You have to "bring out of hiding lurking enemy remnants and scattered all over the cracks of the social machine, their masked cunningly tentacles", said Bolesław Bierut (Cited from: A. Paczkowski, Pół wieku dziejów Polski 1939-1989, Warszawa 1995, p. 257).

36 AINR Po, 060/65, vol. 10, Analiza terenu powiatu szprotawskiego $\mathrm{z}$ uwidocznieniem wrogich środowisk, 2 IX 1952, c. 15.

37 Ibidem.

38 Ibidem.
WUBP w Zielonej Górze, prowadząc cztery sprawy operacyjne, inwigilowała 134 osoby. W tym samym czasie powiatowe UBP w ramach 18 spraw obiektowych kontrolowały aż 512 „figurantów”"34. Był to czas finalizowania w skali całego kraju wspomnianej operacji o kryptonimie „C-1”.

Zintensyfikowanie działań operacyjnych wobec ludności ukraińskiej było zarówno pochodną narastającej rywalizacji między „obozem pokoju” a blokiem państw zachodnich, jak też i konsekwencją przyjęcia przez władze Polski Ludowej tezy o „zaostrzeniu walki klasowej w miarę postępów socjalizmu”. Od 1948 r. represjonowano nie tylko zadeklarowanych wrogów systemu, ale całe grupy społeczne, które uznano za potencjalnie niebezpieczne. Skutkiem tego tysiące Ukraińców w Polsce trafiło do prowadzonego przez „bezpiekę" „rejestru elementu przestępczego i podejrzanego", który z czasem objął ok. 6 mln nazwisk obywateli polskich ${ }^{35}$. Z roku na rok wyraźnie rozbudowywano katalog zarzutów stawianych w licznych sprawozdaniach ukraińskich przesiedleńcom, zręcznie łącząc ich związki $\mathrm{z}$ podziemiem $\mathrm{z}$ rzekomym sabotowaniem realizacji planu sześcioletniego ${ }^{36}$. Dawni członkowie OUN i UPA mieli w odczu-

34 AIPN Po, 060/45, t. 11, Stan rozpracowań po linii Sekcji II Wydziału III WUBP w Zielonej Górze na dzień 28 II 1954 r., 5 III 1954, k. 50.

35 Jak stwierdził Bolesław Bierut, trzeba „wydobyć $z$ ukrycia przyczajone niedobitki wroga i rozsiane po wszystkich szczelinach machiny społecznej, chytrze zamaskowane jego macki" (cyt. za A. Paczkowski, Pół wieku dziejów Polski 1939-1989, Warszawa 1995, s. 257).

36 AIPN Po, 060/65, t. 10, Analiza terenu powiatu szprotawskiego $\mathrm{z}$ uwidocznieniem wrogich środowisk, 2 IX 1952, k. 15. 
in the OUN-UPA" was conducted. There were more than twenty operational cases of the various categories in the province. The broadest scope came to the objectoriented surveillance codename "Lemko", which included file folders for about 100 people. Because of the less operational importance, 33 partial cases were decided to be passed to the county UBPs, and 6 were archived. "On the account" of Section X of the Division I with only materials concerning persons who maintain broader contacts in Poland and abroad with a "nationalist element" were left. Similarly, the existing network of agents was analyzed. Some secret collaborators were eliminated because of inability to continue work, others were assigned to lower level offic$\mathrm{ers}^{39}$. A further decline in operational activity in the Ukrainian environment was accompanied by a reorganization of the security force (replacing the liquidated MBP with the establishment of the Public Security Committee and the Ministry of the Interior) and changing the competencies of individual cells of the political police. Due to gaps in the documentation, it is difficult to uniquely determine the allocation of the Ukrainian issue in $1955^{40}$. However,

39 AINR Po, 060/43, vol. 6, Wykaz spraw Sekcji X Wydziału I WUBP w Zielonej Górze nadających się do dalszego prowadzenia przez Sekcję X, 23 XI 1954, c. 14-22 and 41-44.

40 According to Jarosław Syrny's findings referring to the Wroclaw province, after the initial transmission of the issues of the Ukrainian Section $\mathrm{V}$ of Division II (still dealing with the counterintelligence division) of the provincial Uds.BP, at the end of April 1955 it was decided to place it in the field of interest of Section VI of the same Division (J. Syrnyk, ciu pracowników policji politycznej utrudniać akcję kolektywizacji wsi ${ }^{37}$. Obawiano się też przenikania osób niepewnych pod względem ideowym do administracji i wykorzystywania przez nie zajmowanych stanowisk do działań sprzecznych z ówczesną linią polityczną władz ${ }^{38}$.

W połowie $1954 \mathrm{r}$. doszło do reorganizacji działań centralnego i wojewódzkiego aparatu bezpieczeństwa w środowisku ukraińskim. Do końca tego roku wszystkie dotychczasowe sprawy dotyczące Ukraińców przejęli funkcjonariusze kontrwywiadu z Wydziału X Departamentu I MBP. W województwie zielonogórskim ich wytyczne realizowali podwładni z Sekcji X Wydziału I WUBP w Zielonej Górze. Najprawdopodobniej w rezultacie stopniowej redukcji personelu policji politycznej w październiku 1954 r. przeprowadzono weryfikację dotychczasowej pracy dotyczącej „nacjonalistów ukraińskich podejrzanych o działalność organizacyjną w OUN-UPA". W skali województwa było to przeszło dwadzieścia spraw operacyjnych różnej kategorii. Największy zasięg przybrało rozpracowanie obiektowe krypt. „Łemko”, w które włączono teczki ewidencyjne dotyczące ok. stu osób. Trzydzieści trzy cząstkowe sprawy $\mathrm{z}$ tegoż zbiorczego rozpracowania, ze względu na mniejszą wagę operacyjną, zdecydowano się przekazać powiatowym UBP, a sześć złożono w archiwum. „Na koncie” Sekcji X Wydziału I pozostawiono jedynie materiały dotyczące osób utrzymujących szersze kontakty w kraju i za granicą

$$
\begin{array}{ll}
37 & \text { Ibidem. } \\
38 & \text { Ibidem. }
\end{array}
$$


as early as February 1956 (perhaps slightly earlier), the issue of the Ukrainian Section V of the Division II of the Public Security Office (WUdsBP) in Zielona Góra. Officials employed in the mentioned cell also dealt with the surveillance of "white emigration". Within the operational case codenamed "Biali", there were materials covering only fourteen "nationalists", including four non - commissioned officers from Symon Petlura's army. As it was conceded, "because of the lack of a valuable agents in this environment it was impossible to find any connections [of the 'figurants'] with" intelligence centers of capitalist states" ${ }^{\prime 1}$. It was acknowledged that frequent changes in the management and staff of Section V, the reduction of employment in the cells on the county level and shrinking of the agent network did not favor effective work. Employees responsible for the Ukrainian issue were accused of lack of appropriate plans of operational undertakings and improper handling of cases. The latter, after making a few superficial notes, were usually closed and directed to the archive ${ }^{42}$.

Organizacja pracy organów bezpieczeństwa $w$ zakresie działania wobec ludności ukraińskiej na Dolnym Śląsku (1947-1989), artykuł zamieszczony na stronie internetowej http://www.iukraina.pl [access on: 10.05.2012].

${ }^{41}$ AINR Po, 0038/35, vol. 1, Analiza kontrwywiadowcza województwa zielonogórskiego po zagadnieniu nacjonalizmu rosyjskiego, 12 I 1956, c. 4143; ibidem, Postanowienie o założeniu teczki obiektowej - zagadnieniowej, 3 III 1956, c. 2.

42 AINR Po, 0038/27, vol. 1, Kontrwywiadowcza charakterystyka terenu województwa zielonogórskiego po zagadnieniu nacjonalizmu ukraińskiego, 13 II 1956, c. 1-2. z „elementem nacjonalistycznym”. Podobnie zlustrowano dotychczasową sieć agenturalną. Część tajnych współpracowników wyeliminowano ze względu na nieprzydatność do dalszej pracy, innych powierzono funkcjonariuszom niższego szczebla ${ }^{39}$. Dalszemu spadkowi aktywności operacyjnej w środowisku ukraińskim towarzyszyła reorganizacja resoru bezpieczeństwa (w miejsce zlikwidowanego MBP powołano Komitet ds. Bezpieczeństwa Publicznego i Ministerstwo Spraw Wewnętrznych) oraz zmiana kompetencji poszczególnych komórek policji politycznej. Ze względu na luki w dokumentacji trudno jednoznacznie określić przydział zagadnienia ukraińskiego w 1955 r. ${ }^{40}$ Jednak już w lutym 1956 r. (może nieco wcześniej) następuje całkowite przekazanie zagadnienia ukraińskiego Sekcji V Wydziału II Wojewódzkiego Urzędu ds. Bezpieczeństwa Publicznego (WUdsBP) w Zielonej Górze. Funkcjonariusze zatrudnieni w wymienionej komórce zajęli się też rozpracowaniem, „białej emigracji". W ramach sprawy operacyjnej o kryptonimie „Biali” zgromadzono materiały dotyczące zaledwie czternastu "nacjonalistów", w tym czterech podoficerów

39 AIPN Po, 060/43, t. 6, Wykaz spraw Sekcji X Wydziału I WUBP w Zielonej Górze nadających się do dalszego prowadzenia przez Sekcję X, 23 XI 1954, k. 14-22 oraz 41-44.

40 Według ustaleń Jarosława Syrnyka, odnoszących się do województwa wrocławskiego, po początkowym przekazaniu problematyki ukraińskiej Sekcji V Wydziału II (w dalszym ciagu mamy do czynienia z pionem kontrwywiadowczym) wojewódzkiego Uds.BP, pod koniec kwietnia 1955 r. zdecydowano się umieścić ją w polu zainteresowania Sekcji VI tego samego Wydziału (J. Syrnyk, Organizacja pracy organów bezpieczeństwa $w$ zakresie działania wobec ludności ukraińskiej na Dolnym Śląsku (1947-1989), artykuł zamieszczony na stronie internetowej http:// www.iukraina.pl [dostęp: 10.05.2012]. 
Until 1956 the agents recruited "on patriotic feelings" during the resettlement action, or during their stay at the COP in Jaworzno dominated by the number among the secret collaborators operating in the Ukrainian environment. Chronologically, the oldest group of agents were the persons obtained by the Security Office officers at the resettlement sites. The frightened or often unaware of the consequences, people were prompted to sign the paper with a ready-made, standardized commitment: "I pledge to cooperate voluntarily with the Security Authorities, to inform you of any manifestations of diversion, and of persons who are stirring up in Polish society" or "I undertake to detect any enemies of the Democratic Polish Government" ${ }^{\text {"43 }}$. These documents were sent to "UB representatives at the site of unloading". Considering the fragmentary data, it was known that the PUBP officers in Sulęcin received the personal details of 12 informants "acquired" at the Grybów resettlement point ${ }^{44}$. Their colleagues from PUBP in Głogów received materials about the confidents nicknamed "Mania", "Rosły", "Student" and "Leśny"45. In the early months of 1948 , some former Jaworzno prisoners were forced to continue the cooperation, which had been

43 AINR Po, 0038/27, vol. 4, Wykaz zawerbowanych z akcji "W", n.d., c. 133-141.

44 AINR Po, 0038/35, vol. 2, Meldunek specjalny do sekcji I Wydziału III WUBP w Poznaniu, 12 VII 1947, c. 53.

45 AINR Po, 0038/27, vol. 4, Pismo delegata MBP do przedstawiciela UB w miejscu rozładowania transportu, n. d., c. 108. $\mathrm{z}$ armii Symona Petlury. Jak przyznawano, „z braku cennej agentury w tym środowisku nie zdołano stwierdzić jakichkolwiek powiązań [»figurantów «] z ośrodkami wywiadowczymi państw kapitalistycznych"41. Przyznawano, że częste zmiany kierownictwa i personelu Sekcji V, redukcja zatrudnienia w komórkach szczebla powiatowego oraz kurczenie się sieci agenturalnej nie sprzyjały prowadzeniu efektywnej pracy. Pracownikom odpowiedzialnym za zagadnienie ukraińskie zarzucano brak odpowiednich planów przedsięwzięć operacyjnych i niewłaściwe prowadzenie spraw. Te ostatnie po sporządzeniu kilku powierzchownych notatek zazwyczaj zamykano i kierowano do $\operatorname{archiwum}^{42}$.

Do 1956 r. wśród tajnych współpracowników działających w środowisku ukraińskim dominowali pod względem liczebności konfidenci zwerbowani „na uczuciach patriotycznych" podczas akcji przesiedleńczej lub też w trakcie pobytu w COP w Jaworznie. Chronologicznie najstarszą grupe agentury stanowily osoby pozyskane przez funkcjonariuszy Urzędu Bezpieczeństwa w punktach przesiedleńczych. Zastraszonym czy też często nieświadomym konsekwencji osobom podsuwano do podpisu kartki z gotowym już, standardowym zobowiązaniem o treści: „Zobowiązuję się dobrowolnie współpracować z Organami Bezpieczeństwa, informować o wszel-

41 AIPN Po, 0038/35, t. 1, Analiza kontrwywiadowcza województwa zielonogórskiego po zagadnieniu nacjonalizmu rosyjskiego, 12 I 1956, k. 41-43; ibidem, Postanowienie o założeniu teczki obiektowej - zagadnieniowej, 3 III 1956, k. 2.

42 AIPN Po, 0038/27, t. 1, Kontrwywiadowcza charakterystyka terenu województwa zielonogórskiego po zagadnieniu nacjonalizmu ukraińskiego, 13 II 1956, k. 1-2. 
established in the camp, in the Zielona Góra province. There was an informant ps. "Siekiera" among them, who settled in the area of Strzelce district ${ }^{46}$.

We are not able to determine accurately the number of the agents penetrating the Ukrainian environment in Ziemia Lubus$\mathrm{ka}$ in the late 1940s due to incomplete data and its affiliation to two separate provinces. As of June 1, 1949, the structures of the security apparatus in the Poznan province used only 24 agents in the Ukrainian issue, while their counterparts in the Wrockaw province were $102^{47}$. The full data is obtained when the Zielona Góra province was established, and with it the WUBP was established in Zielona Góra. Section II of the Division III of WUBP, i.e. the unit of the Ukrainians, Belarussians, Lithuanians and Russians, and the posts III of county UBPs in the end of August 1950 used a total of 2 residents, 2 agents and 60 informants in their operations against the mentioned nationalities ${ }^{48}$.

However, its network of agents did not guarantee effective penetration of the Ukrainian environment. It provided only

46 AINR Po, 0038/27, vol. 11, Protokół z kontroli pracy operacyjnej SB KP MO w Strzelcach Krajeńskich po zagadnieniu nacjonalizmu ukraińskiego, 9 I 1960, c. 106.

47 T. Balbus, Rozpracowanie agenturalne środowisk ukraińskich $w$ Polsce $w 1949$ roku, "Biuletyn Instytutu Pamięci Narodowej” 2001, No. 8, p. 35; AINR Po, 003/261, Wykaz spraw prowadzonych po linii akcji "W” przez Sekcję I Wydziału III WUBP w Poznaniu, 20 III 1950, c. 133-134.

48 AINR Po, 060/45, vol. 1, Sprawozdanie miesięczne Wydziału III WUBP w Zielonej Górze za miesiąc sierpień 1950 r., 6 IX 1950, c. 3. kich mi widzianych przejawach dywersji, oraz o osobach siejących ferment w społeczeństwie polskim” lub też „zobowiązuję się wykrywać wszelkich wrogów Demokratycznego Rządu Polskiego"43. Dokumenty te przesyłano do „przedstawicieli UB w miejscu rozładowania”. W świetle cząstkowych danych wiadomo, że funkcjonariusze PUBP w Sulęcinie otrzymali personalia 12 informatorów „pozyskanych" w punkcie przesiedleńczym w Grybowie $^{44}$. Ich koledzy z PUBP w Głogowie otrzymali materiały dotyczące konfidentów o pseudonimach: „Mania”, „Rosły”, „Student" i „Leśny” ${ }^{45}$. W pierwszych miesiącach 1948 r. do sieci agenturalnej w Zielonogórskiem włączono niektórych byłych więźniów Jaworzna, zmuszonych do kontynuowania współpracy zawiązanej jeszcze w obozie. Był wśród nich informator ps. „Siekiera”, który osiadł na terenie powiatu strzeleckiego ${ }^{46}$.

Nie jesteśmy w stanie precyzyjnie ustalić liczebności agentury penetrującej środowisko ukraińskie na Ziemi Lubuskiej pod koniec lat 40. ze względu na niepełne dane i przynależność tego obszaru do dwóch odrębnych województw. Według stanu z 1 czerwca 1949 r. struktury aparatu bezpieczeństwa w województwie po-

43 AIPN Po, 0038/27, t. 4, Wykaz zawerbowanych z akcji „W”, b.d., k. 133-141.

44 AIPN Po, 0038/35, t. 2, Meldunek specjalny do sekcji I Wydziału III WUBP w Poznaniu, 12 VII 1947, k. 53.

45 AIPN Po, 0038/27, t. 4, Pismo delegata MBP do przedstawiciela $\mathrm{UB} \mathrm{w}$ miejscu rozładowania transportu, b.d., k. 108.

46 AIPN Po, 0038/27, t. 11, Protokół z kontroli pracy operacyjnej SB KP MO w Strzelcach Krajeńskich po zagadnieniu nacjonalizmu ukraińskiego, 9 I 1960, k. 106. 
general information on the subject without being able to perform special tasks involving the control of the most suspicious persons, provoking them to resume "anti-state work", or locating and identifying hiding conspirators ${ }^{49}$. The basis for the recruitment of new, effective agents was to be no longer "patriotic feelings" or material benefits, but the so-called compromising materials. In December 1950, twelve candidates for secret collaborants were selected on the basis of the above criteria, which Division II of Department III of MBP was expected to review ${ }^{50}$. The apogee of the development of an agential network operating in the Ukrainian environment in the Zielona Góra province was February 1954. Section II of the Division III then used 3 residents and 12 informants, and county UBPs 2 residents and 59 informants. The officers met the confidents in three contact places $^{51}$. In subsequent months there was a gradual decrease in the number of personal information sources resulting from the elimination of the least useful units, rebuilding of the security apparatus and the gradual limitation of its role. Increasingly, secret collaborators refused to cooperate further with the political police. In Febru-

49 Ibidem, Raport okresowy Wydziału III WUBP w Zielonej Górze za miesiąc listopad 1950 r., 8 XII 1950, c. 27.

50 Ibidem, Raport okresowy Wydziału III WUBP w Zielonej Górze za miesiąc wrzesień 1950 r., 9 X 1950, k. 8; ibidem, Sprawozdanie z pracy Wydziału III WUBP w Zielonej Górze i Referatów III PUBP za miesiąc grudzień 1950 r., 10 I 1951, c. 44.

51 AINR Po, 060/45, vol. 11, Sprawozdanie z pracy Wydziału III WUBP w Zielonej Górze i Referatów III PUBP za miesiąc luty 1954 r., 8 III 1954, c. 36-38. znańskim wykorzystywały po zagadnieniu ukraińskim zaledwie 24 jednostki agenturalne, podczas gdy ich odpowiedniki w województwie wrocławskim aż $102^{47}$. Pełne dane uzyskujemy $z$ chwilą utworzenia województwa zielonogórskiego, a wraz z nim powołania WUBP w Zielonej Górze. Sekcja II Wydziału III WUBP, czyli komórka rozpracowująca Ukraińców, Białorusinów, Litwinów i Rosjan, oraz referaty III powiatowych UBP pod koniec sierpnia $1950 \mathrm{r}$. w działaniach operacyjnych wymierzonych w wymienione grupy narodowościowe wykorzystywały ogółem: 2 rezydentów, 2 agentów i 60 informatorów ${ }^{48}$.

Jednak posiadana sieć agenturalna nie gwarantowała skutecznej penetracji środowiska ukraińskiego. Dostarczała jedynie ogólnych informacji na jego temat, nie mając możliwości wykonywania zadań specjalnych polegających na kontroli najbardziej podejrzanych osób, prowokowaniu ich do wznowienia „roboty antypaństwowej" czy też lokalizowaniu i identyfikowaniu ukrywających się konspiratorów ${ }^{49}$. Podstawą werbunku nowej, efektywnej agentury miały być już nie „uczucia patriotyczne” czy też korzyści materialne, a tzw. materiały kompromitujące. W grudniu 1950 r. opierając się o powyższe kryteria, wy-

47 T. Balbus, Rozpracowanie agenturalne środowisk ukraińskich $w$ Polsce $w 1949$ roku, „Biuletyn Instytutu Pamięci Narodowej" 2001, nr 8, s. 35; AIPN Po, 003/261, Wykaz spraw prowadzonych po linii akcji „W” przez Sekcję I Wydziału III WUBP w Poznaniu, 20 III 1950, k. 133-134.

${ }^{48}$ AIPN Po, 060/45, t. 1, Sprawozdanie miesięczne Wydziału III WUBP w Zielonej Górze za miesiąc sierpień 1950 r., 6 IX 1950, k. 3.

${ }^{49}$ Ibidem, Raport okresowy Wydziału III WUBP w Zielonej Górze za miesiąc listopad 1950 r., 8 XII 1950, k. 27. 
ary 1956 only 12 informants involved in the Ukrainian issue remained in Zielona Góra. Their small number and improper use in operational work prevented comprehensive surveillance of local Ukrainians. It was also suggested that often their low intellectual level, poor health and age had the negative impact on the operability of the informers ${ }^{52}$.

In the years 1957-1965, the surveillance of the Ukrainian minority in Zielona Góra was the domain of two units of Służba Bezpieczeństwa [SB - the Security Service] (i.e. a reorganized repressive apparatus) - Group III of the Division III and Group V of the Division II of the Civic Militia Headquarters (KW MO) in Zielona Góra. Their tasks in the field were carried out by the officers of the Security Units in the County Headquarters of the Civic Militia (KP MO). The task of the Division III of SB (subordinated to the Central Department of the Ministry of Interior) was to provide a comprehensive monitoring of the processes taking place in the Ukrainian community, to combat "negative" attitudes among Ukrainians, to ensure "proper" functioning of the Ukrainian Society for Social and Cultural Affairs (UTSK) as well as Greek Catholic and orthodox religious institutions, as well as the search for and bringing to justice the recently hiding members of the conspiracy and the former police and military services. The counterintelligence division (headed by Depart-

52 AINR Po, 0038/27, vol. 1, Kontrwywiadowcza charakterystyka terenu województwa zielonogórskiego po zagadnieniu nacjonalizmu ukraińskiego, 13 II 1956, c. 1-2. typowano dwunastu kandydatów na tajnych współpracowników, których miał zaopiniować Wydział II Departamentu III $\mathrm{MBP}^{50}$. Apogeum rozwoju sieci agenturalnej działającej w środowisku ukraińskim w Zielonogórskiem przypada na luty 1954 r. Sekcja II Wydziału III wykorzystywała wówczas 3 rezydentów i 12 informatorów, a powiatowe UBP 2 rezydentów i 59 informatorów. Z konfidentami spotykano się w trzech lokalach kontaktowych ${ }^{51}$. W kolejnych miesiącach następuje stopniowy spadek liczby osobowych źródeł informacji, który był wynikiem eliminowania jednostek najmniej przydatnych, przebudowy aparatu bezpieczeństwa i stopniowego ograniczania jego roli. Coraz częściej tajni współpracownicy odmawiali dalszego współdziałania z policją polityczną. W lutym 1956 r. pozostało w Zielonogórskiem zaledwie 12 informatorów zaangażowanych w problematykę ukraińską. Ich niewielka liczba i niewłaściwe wykorzystanie w pracy operacyjnej uniemożliwiało prowadzenie kompleksowej inwigilacji miejscowych Ukraińców. Sugerowano też, że ujemny wpływ na operatywność informatorów miały też często ich niski poziom intelektualny, zły stan zdrowia i podeszły wiek ${ }^{52}$.

50 Ibidem, Raport okresowy Wydziału III WUBP w Zielonej Górze za miesiąc wrzesień 1950 r., 9 X 1950, k. 8; ibidem, Sprawozdanie z pracy Wydziału III WUBP w Zielonej Górze i Referatów III PUBP za miesiąc grudzień 1950 r., 10 I 1951, k. 44.

51 AIPN Po, 060/45, t. 11, Sprawozdanie z pracy Wydziału III WUBP w Zielonej Górze i Referatów III PUBP za miesiąc luty 1954 r., 8 III 1954, k. 36-38.

52 AIPN Po, 0038/27, t. 1, Kontrwywiadowcza charakterystyka terenu województwa zielonogórskiego po zagadnieniu nacjonalizmu ukraińskiego, 13 II 1956, k. 1-2. 
ment II of the Ministry of Interior) was responsible for cases of the alleged contacts of local Ukrainians with the intelligence services of foreign states and the Ukrainian-based immigrant organizations cooperating with them. The indicated thematic division was in fact not very precise, causing numerous complications. As a result of this, collaborators of Group III of the Division III KW MO were relatively frequently involved in counterintelligence activities involving attempts to infiltrate the Ukrainian diaspora in the West. During the next nationwide reorganization of the Ministry of Security, this unit took over the whole of the documentation and the network of agents of Group V of the Division II. Somewhat earlier, officers of the Division IV of KW MO joined the surveillance of the religious life of Ukrainians.

In the years 1956-1959 the Ukrainian people placed high hopes in the Ukrainian Social and Cultural Association (UTSK) the organization licensed by the authorities, which for some time became the actual expresser of the interests of Ukrainians in Poland. For those who joined the UTSK ranks it became clear that the Society's activities would focus on the removal of the effects of deportation and the organization of mass return home. This motif pushed many people to work in the social field in Ziemia Lubuska, who in 1956, despite differences in perception of the Lemko problem, entered the local UTSK units $^{53}$. In the meantime, in 1957, further

53 In addition to the UTSK Regional Executive Board in Zielona Góra, subordinated units in Szpro-
W latach 1957-1965 rozpracowanie mniejszości ukraińskiej w województwie zielonogórskim było domeną dwóch ogniw Służby Bezpieczeństwa (czyli zreorganizowanego aparatu represji) - Grupy III Wydziału III oraz Grupy V Wydziału II Komendy Wojewódzkiej Milicji Obywatelskiej (KW MO) w Zielonej Górze. Ich zadania $\mathrm{w}$ terenie realizowali funkcjonariusze Referatów ds. Bezpieczeństwa w Komendach Powiatowych Milicji Obywatelskiej (KP MO). Do zadań pionu trzeciego SB (podporządkowanego na szczeblu centralnym Departamentowi III Ministerstwa Spraw Wewnętrznych [MSW]) należało: kompleksowe monitorowanie procesów zachodzących w społeczności ukraińskiej, zwalczanie „negatywnych” postaw wśród Ukraińców, zapewnienie "prawidłowego" funkcjonowania Ukraińskiego Towarzystwa Społeczno-Kulturalnego (UTSK) oraz greckokatolickich i prawosławnych placówek wyznaniowych, a także poszukiwanie i stawianie przed wymiarem sprawiedliwości ostatnich ukrywających się członków konspiracji i dawnych służb policyjnych i wojskowych. W kompetencjach pionu kontrwywiadowczego (kierował nim Departament II MSW) pozostawiono sprawy, w których rozpatrywano domniemane kontakty miejscowych Ukraińców ze służbami wywiadowczymi obcych państw i współdziałającymi z nimi ukraińskimi organizacjami emigracyjnymi. Wskazany podział tematyczny był w gruncie rzeczy niezbyt precyzyjny, powodujący liczne komplikacje. Skutkiem tego w działania o charakterze kontrwywiadowczym, polegające na próbach infiltrowania diaspory ukraińskiej na Za- 
moves by the Polish authorities actually reduced the possibility of resettlement of the Ukrainian population to their former territor $y^{54}$. Unfavorable settlements caused sharp opposition from the UTSK activists in Zielona Góra region. In September 1957, at the initiative of Paweł Stefanowski, documents were written that criticized the current state policy towards the Ukrainians. These conclusions were sent to the local and central authorities and to all UTSK regional branches in the country. It was intended to develop a common line of action for the future ${ }^{55}$.

In the largest concentrations of Ukrainian population on Ziemia Lubuska, a number of meetings were organized during

tawa, Głogów, Międzyrzecz, Skwierzyna, Strzelce Krajeńskie, Nowa Sól and Świebodzin were established. According to estimates by Stefan Dudra about three hundred people took part in the activity of UTSK in Zielonogórskie region in 1956-1958 (S. Dudra, Łemkowie. Deportacja i osadnictwo ludności łemkowskiej na Środkowym Nadodrzu w latach 1947-1960, Głogów 1998, p. 132).

54 This is primarily a question of the resolution of the Secretariat of the Central Committee of the PZPR "on the Ukrainian national minority in the People's Republic of Poland" of April 1957, which concerned the strengthening of the state of development of Ukrainians in the Western Territories and the regulation of individual and group returns and the November resolution of the Presidencies of WRN in Kraków and Rzeszów referring to settlements 2.5 thousand highlanders from Cracow province in south-east part of Rzeszow province (R. Drozd, Polityka władz wobec ludności ukraińskiej $w$ Polsce w latach 1944-1989, Warszawa 2001, pp. 174-178).

55 AINR Po, 0038/27, vol. 1, Analiza kontrwywiadowcza terenu województwa zielonogórskiego po zagadnieniu mniejszości ukraińskiej, 18 VIII 1958, c. 6-23; ibidem, Notatka służbowa z rozmowy przeprowadzonej z figurantem sprawy ewidencyjno-obserwacyjnej kryptonim "Organizator", 4 II 1960 , c. 361 chodzie, angażowano stosunkowo często tajnych współpracowników Grupy III Wydziału III KW MO. To ogniwo w 1965 r., $\mathrm{w}$ trakcie kolejnej ogólnopolskiej reorganizacji resortu bezpieczeństwa, przejęło całość dokumentacji oraz sieć agenturalną Grupy V Wydziału II. Nieco wcześniej $\mathrm{w}$ inwigilację życia wyznaniowego Ukraińców włączyli się funkcjonariusze Wydziału IV KW MO.

W latach 1956-1959 ludność ukraińska pokładała duże nadzieje w Ukraińskim Towarzystwie Społeczno-Kulturalnym (UTSK) - koncesjonowanej przez władze organizacji, która na pewien czas stała się faktycznym wyrazicielem interesów Ukraińców w Polsce. Dla osób, które wstąpiły w szeregi UTSK, było oczywiste, że działalność Towarzystwa skoncentruje się na likwidacji skutków deportacji i zorganizowaniu masowych powrotów w ojczyste strony. Motyw ten pchnął do pracy na polu społecznym wiele osób na Ziemi Lubuskiej, które w 1956 r., mimo różnic w postrzeganiu problemu łemkowskiego, weszły do lokalnych ogniw UTSK $^{53}$. Tymczasem w 1957 r. kolejne posunięcia polskich władz faktycznie ograniczyły możliwości ponownego osiedlenia się ludności ukraińskiej na jej dawnym te-

${ }^{53}$ Oprócz Zarządu Wojewódzkiego UTSK w Zielonej Górze powstały podporzadkowane mu ogniwa powiatowe w: Szprotawie, Głogowie, Międzyrzeczu, Skwierzynie, Strzelcach Krajeńskich, Nowej Soli i Świebodzinie. Według szacunków Stefana Dudry w działalności UTSK w Zielonogórskiem w latach 1956-1958 wzięło udział ok. 300 osób (S. Dudra, Łemkowie. Deportacja i osadnictwo ludności łemkowskiej na Środkowym Nadodrzu w latach 19471960, Głogów 1998, s. 132). 
which the problem of return was discussed. An attempt was made to settle this issue through the courts. Several residents of Szprotawa county (Mirosław Worchacz, Mikołaj Szlachtycz and Józef Merena) and Gorzów Wielkopolski (Konstanty Halkowicz) hired lawyer Piotr Leszczyński, who was to demand from the authorities of the Polish People's Republic redress for the unlawful expulsion of the inhabitants of Podkarpacie region as part of the "Vistula" operation. These persons acted in consultation with the UTSK activists from Zielona Góra. They visited the Ukrainian settlements where they made appropriate applications and collected funds to pay court fees ${ }^{56}$. This initiative did not go unnoticed by SB, which already in 1957 initiated the recording and observation cases of codenames "Krain" and "Powrót". They also invigilated the alleged "inspirators" of the action - the activists of Regional Board of UTSK in Zielona Góra: Jan Czerhoniak, Jan Krynicki, Andrzej Stawiski and Antoni Dziubiński (the agent-group case, later record-observation codename "Odnowa" was set against all the four persons) and Michał Kowalski (the record-observation case codename "Próba") ${ }^{57}$. To discourage the Ukrainian population in the future from organizing similar undertakings it was decided that at least some people

${ }^{56}$ AINR Po, 0038/27, vol. 5, Charakterystyka po linii nacjonalizmu ukraińskiego w powiecie Nowa Sól, 19 III 1958, c. 3.

${ }^{57}$ AINR Po, 0038/27, vol. 1, Streszczenie sprawy ewidencyjno-obserwacyjnej "Powrót", 14 V 1959 , c. 225. rytorium ${ }^{54}$. Niekorzystne rozstrzygnięcia wywołały ostry sprzeciw ze strony zielonogórskiego aktywu UTSK. We wrześniu 1957 r. z inicjatywy Pawła Stefanowskiego opracowano dokumenty poddające krytyce dotychczasową politykę państwa wobec Ukraińców. Wnioski te przesłano władzom terenowym i centralnym oraz wszystkim ogniwom wojewódzkim UTSK w kraju. Zamierzano opracować wspólną linię działania na przyszłość 55 .

W największych skupiskach ludności ukraińskiej na Ziemi Lubuskiej zorganizowano wiele spotkań, podczas których omawiano problem powrotów. Podjęto próbę rozstrzygnięcia tej kwestii na drodze sądowej. Kilku mieszkańców powiatu szprotawskiego (Mirosław Worchacz, Mikołaj Szlachtycz i Józef Merena) i Gorzowa Wielkopolskiego (Konstanty Halkowicz) wynajęło adwokata Piotra Leszczyńskiego, który miał domagać się od władz Polski Ludowej zadośćuczynienia za bezprawne wysiedlenie mieszkańców Podkarpacia w ramach akcji „Wisła”. Wymienione osoby działały w porozumieniu

${ }^{54}$ Mowa tu przede wszystkim o uchwale Sekretariatu KC PZPR „w sprawie ukraińskiej mniejszości narodowej w PRL" z kwietnia 1957 r., która dotyczyła umocnienia stanu zagospodarowania Ukraińców na Ziemiach Zachodnich oraz uregulowania indywidualnych i grupowych powrotów oraz listopadowej uchwale Prezydiów WRN w Krakowie i Rzeszowie ws. osiedlenia na terenach pd. wschodniej Rzeszowszczyzny 2,5 tys. górali z Krakowskiego (R. Drozd, Polityka władz wobec ludności ukraińskiej w Polsce w latach 1944-1989, Warszawa 2001, s. 174-178).

55 AIPN Po, 0038/27, t. 1, Analiza kontrwywiadowcza terenu województwa zielonogórskiego po zagadnieniu mniejszości ukraińskiej, 18 VIII 1958, k. 6-23; ibidem, Notatka służbowa z rozmowy przeprowadzonej z figurantem sprawy ewidencyjno-obserwacyjnej kryptonim „Organizator”, 4 II 1960, k. 361. 
implicated in the case would be charged with breaking the tax law. In agreement with the prosecution body, an investigation was launched, which, though later was dismissed "for political reasons", but the desired effect was achieved. As it was later found, the preventive and warning talks, conducted with the participation of a prosecutor, with Merena, Szlachtycz and Worchacz effectively suppressed their "propaganda tendencies" and led to leaving $\mathrm{UTSK}^{58}$. Also attorney Leszczyński, subjected to pressure of the representatives of the Office of Internal Affairs Bureau of the Provincial National Council (USW PWRN), resigned from the representation of displaced Lemkos. At the same time, in November 1957, personal purge was brought in the Zielona Gora Provincial Board. Outgoing activists, the already mentioned "figurants" of the case "Odnowa", were charged with conducting activities incompatible with the statute of the Society ${ }^{59}$.

Due to the failure to organize mass returns to the south-east of the country based on the UTSK, in the spring of 1958 ,

58 Ibidem, Analiza kontrwywiadowcza terenu województwa zielonogórskiego po zagadnieniu mniejszości ukraińskiej, 18 VIII 1958, c. 6-23; AINR Po, 0038/27, vol. 14, Charakterystyka Mereny Józefa, 10 X 1961, c. 166; ibidem, Charakterystyka Szlachtycza Michała, 10 X 1961, c. 167; ibidem, Charakterystyka Worchacza Mirosława, 10 X 1961, c. 169.

59 AINR Po, 0038/27, vol. 1, Analiza kontrwywiadowcza terenu województwa zielonogórskiego po zagadnieniu mniejszości ukraińskiej, 18 VIII 1958, c. 6-23; See more: J. Syrnyk, Ukraińskie Towarzystwo Społeczno-Kulturalne (1956-1990), Wrocław 2008, pp. 279-306. z zielonogórskim aktywem UTSK. Wizytowały ukraińskie osady, gdzie sporząazały stosowne podania i zbierały fundusze na opłacenie kosztów sądowych ${ }^{56}$. Powyższa inicjatywa nie umknęła uwadze SB, która już w 1957 r. wszczęła sprawy ewidencyjno-obserwacyjne o kryptonimach „Krain” i „Powrót”. Inwigilacji w ramach odrębnych rozpracowań poddano także domniemanych „inspiratorów” akcji - działaczy ZW UTSK w Zielonej Górze: Jana Czerhoniaka, Jana Krynickiego, Andrzeja Stawiskiego, Antoniego Dziubińskiego (całej czwórki dotyczyła sprawa agenturalna grupowa, później ewidencyjno-obserwacyjna krypt. „Odnowa”) i Michała Kowalskiego (sprawa ewidencyjno-obserwacyjna krypt. „Próba”) $)^{57}$. Aby zniechęcić ludność ukraińską do organizowania w przyszłości podobnych zamierzeń, podjęto decyzję, aby przynajmniej niektórym osobom zamieszanym $\mathrm{w}$ sprawę postawić zarzuty łamania prawa skarbowego. W porozumieniu $\mathrm{z}$ organami prokuratorskimi wszczęto śledztwo, które co prawda później umorzono „z przyczyn politycznych”, jednak osiągnięto zamierzony skutek. Jak nieco później stwierdzono, rozmowy profilaktyczno-ostrzegawcze przeprowadzone przy udziale prokuratora z Mereną, Szlachtyczem i Worchaczem skutecznie zahamowały ich "zapędy propagandowe" i doprowadziły do wystąpienia z UTSK ${ }^{58}$. Tak-

56 AIPN Po, 0038/27, t. 5, Charakterystyka po linii nacjonalizmu ukraińskiego w powiecie Nowa Sól, 19 III 1958, k. 3.

57 AIPN Po, 0038/27, t. 1, Streszczenie sprawy ewidencyjno-obserwacyjnej „Powrót”, 14 V 1959, k. 225.

58 Ibidem, Analiza kontrwywiadowcza terenu województwa zielonogórskiego po zagadnieniu 
among the displaced persons from Lemkivshchyna a group of people appeared who declared distinctiveness from the Ukrainian population and made an attempt to establish an independent Lemko organization. In Zielona Góra region Jarosław Merena, Paweł Stefanowski and Jarosław Zwoliński were among its leaders. The emigration Lemko-Soyuz, a leftwing organization, friendly to the communist countries (until 1967 also Poland), promoted the idea of the existence of the separate "Rusyn" (or "Carpathian-Rusyn") people. It was assumed that the new Lemkos association in Poland, cutting off from the Ukrainian nationalists, would reach an agreement with the authorities in Warsaw, would get a consent to mass return and legal co-financing of the resettlement action by the emigrants ${ }^{60}$. In May 1958, Merena and Stefanowski attempted "under the cover" of a dance party to organize the Lemko convention in Głogów, during which the temporary management of the new organization was planned. Although the meeting did not take place, as a result of counteracting of SB, KW PZPR and administrative authorities and boycott of the UTSK activists, still in the same month they managed to appoint the Temporary Organizing Committee of Rusyns - Lemkos in Zielona Góra (private residence of Stefanowski). Declarations and writings were issued to the leaders of the CPSU and PZPR: Niki-

${ }^{60}$ AINR Po, 0038/27, vol. 4, Analiza polityczna materiałów po zagadnieniu nacjonalizmu ukraińskiego za rok 1959, 15 XII 1959, c. 167-168. że mecenas Leszczyński, poddany presji przedstawicieli Urzędu Spraw Wewnętrznych Prezydium Wojewódzkiej Rady Narodowej (USW PWRN), zrezygnował $\mathrm{z}$ reprezentowania łemkowskich przesiedleńców. Równocześnie doprowadzono w listopadzie $1957 \mathrm{r}$. do czystki personalnej w Zarządzie Wojewódzkim w Zielonej Górze. Ustępującym działaczom, wymienionym już „figurantom” sprawy „Odnowa”, postawiono zarzut prowadzenia działalności niezgodnej ze statutem Towarzystwa ${ }^{59}$.

W związku z fiaskiem zorganizowania masowych powrotów na południowy-wschód kraju opartych na UTSK, wiosną 1958 r. wśród przesiedleńców z Łemkowszczyzny uaktywniła się grupa deklarująca odrębność od ludności ukraińskiej, czyniąca próby powołania samodzielnej łemkowskiej organizacji. W Zielonogórskiem do jej liderów zaliczano Jarosława Merenę, Pawła Stefanowskiego i Jarosława Zwolińskiego. Wpływ na ich poczynania miał zapewne emigracyjny Łemko-Sojuz - organizacja lewicowa, przyjazna krajom komunistycznym (do 1967 r. także Polsce), lansująca ideę istnienia odrębnego narodu „rusińskiego” (względnie „karpatorusińskiego"). Zakładano, że nowe łemkowskie stowarzyszenie w Polsce, odcinając się od ukraińskich nacjonalistów, wypracuje

mniejszości ukraińskiej, 18 VIII 1958, k. 6-23; AIPN Po, 0038/27, t. 14, Charakterystyka Mereny Józefa, 10 X 1961, k. 166; ibidem, Charakterystyka Szlachtycza Michała, 10 X 1961, k. 167; ibidem, Charakterystyka Worchacza Mirosława, 10 X 1961, k. 169.

59 AIPN Po, 0038/27, t. 1, Analiza kontrwywiadowcza terenu województwa zielonogórskiego po zagadnieniu mniejszości ukraińskiej, 18 VIII 1958, k. 6-23; zob. szerzej J. Syrnyk, Ukraińskie Towarzystwo Społeczno-Kulturalne (1956-1990), Wrocław 2008, s. 279-306. 
ta Khrushchev and Władysław Gomułka with the request for the legalization of the Lemko Society in Poland. The finale of these proceedings was brought by a meeting at the Central Committee of the Polish United Workers' Party in August 1958, during which the activities of the Lemko group were unambiguously defined as illegal. This was a signal for the Zielona Góra $\mathrm{SB}$ (Division III of KW MO) to intensify the surveillance of this environment. The group agent case, codenamed "Akcja”, was launched in close cooperation with SB units from other provinces ${ }^{61}$. Outlined during this time, the operational plans of SB included the acquisition of agents within the Lemko group, which would not only recognize its future plans and links with emigration, but would also effectively paralyze attempts to legalize and expand its own organizational structures. It was intended to take advantage of discrepancies between Lemkos and UTSK activists. These plans became obsolete as Paweł Stefanowski and Jarosław Zwoliński left the Zielona Góra province. By the same token, it was stated, "the tendencies to create a separate Lemko organization failed" 62 .

61 AINR Po, 0038/27, vol. 1, Analiza kontrwywiadowcza terenu województwa zielonogórskiego po zagadnieniu mniejszości ukraińskiej, 18 VIII 1958, c. 6-23; ibidem, Sytuacja operacyjna po zagadnieniu nacjonalizmu ukraińskiego, 23 IX 1958, c. 137-138.

62 Ibidem, Analiza kontrwywiadowcza terenu województwa zielonogórskiego po zagadnieniu mniejszości ukraińskiej, 18 VIII 1958, c. 6-23; ibidem, Sprawozdanie Grupy III Wydziału III KW MO w Zielonej Górze po zagadnieniu nacjonalizmu ukraińskiego za III kwartał 1959 r., 25 IX 1959, c. 272. porozumienie $\mathrm{z}$ władzami w Warszawie, uzyska zgodę na masowe powroty i legalne dofinansowanie akcji przesiedleńczej przez emigrantów ${ }^{60}$. W maju 1958 r. Merena i Stefanowski usiłowali „pod przykrywką” zabawy tanecznej zorganizować w Głogowie zjazd Łemków, podczas którego zamierzano wyłonić tymczasowy zarząd nowej organizacji. Choć do spotkania nie doszło, w wyniku przeciwdziałania SB, KW PZPR i władz administracyjnych oraz bojkotu ze strony działaczy UTSK, to jeszcze w tym samym miesiącu zdołano powołać w Zielonej Górze (w prywatnym mieszkaniu Stefanowskiego) Tymczasowy Komitet Organizacyjny Rusinów - Łemków. Wystosowano deklaracje i pisma do przywódców KPZR i PZPR Nikity Chruszczowa i Władysława Gomułki z prośbą o legalizację towarzystwa łemkowskiego w Polsce. Finał tych zabiegów przyniosła narada w KC PZPR w sierpniu 1958 r., podczas której jednoznacznie określono działalność grupy łemkowskiej jako nielegalną. Był to sygnał dla zielonogórskiej SB (Wydział III KW MO), aby zintensyfikować rozpracowanie niniejszego środowiska. Wszczęto wówczas sprawę agenturalną grupową o kryptonimie „Akcja”, którą prowadzono w ścisłej współpracy z jednostkami SB z innych województw ${ }^{61}$. Nakreślone w tym czasie plany operacyjne SB obejmowały pozyskanie agentury wewnątrz grupy

60 AIPN Po, 0038/27, t. 4, Analiza polityczna materiałów po zagadnieniu nacjonalizmu ukraińskiego za rok 1959, 15 XII 1959, k. 167-168.

61 AIPN Po, 0038/27, t. 1, Analiza kontrwywiadowcza terenu województwa zielonogórskiego po zagadnieniu mniejszości ukraińskiej, 18 VIII 1958, k. 6-23; ibidem, Sytuacja operacyjna po zagadnieniu nacjonalizmu ukraińskiego, 23 IX 1958, k. 137-138. 
Some displaced people tried to break the government's resistance to return, declaring their will to set up production cooperatives. In May 1959, residents of Torzym (Sulęcin County) Stefan Merena and Andrzej Zwoliński petitioned the Ministry of Agriculture, the State Council and PWRN in Zielona Góra, asking for the possibility of regaining old farms in Nowy Sacz county they were ready to create collective farms there. However, the authorities rejected their request, and the SB unit in Sulęcin set up the registration and observation case codename "Florynka" against the mentioned initiators ${ }^{63}$.

In the years 1957-1959, the priority task of SB, as part of the stabilization of the political system by Władysław Gomułka’s team, was to ensure full control over the social and political organizations that gained some independence on the political "thaw". These included the UTSK and the seed of Lemko organization. The operational plans of the Division III of KW MO in Zielona Góra from mid-1958 took into account the "nationalist tendencies emanating from the UTSK and Lemko activists", the disagreement between the Ukrainian society and the Lemko group, and the scale of the influence of Ukrainian political emigration on these structures. Close cooperation with KW PZPR and

63 AINR Po, 0038/27, vol. 18, Pismo zastępcy komendanta powiatowego MO ds. Bezpieczeństwa do naczelnika Wydziału III KW MO w Zielonej Górze, 16 XII 1959, c. 58-59; AINR Po, 0038/27, vol. 4, Analiza polityczna materiałów po zagadnieniu nacjonalizmu ukraińskiego za rok 1959, 15 XII 1959, c. 168. łemkowskiej, która pozwalałaby nie tylko rozpoznać jej plany na przyszłość i powiązania z emigracją, ale także skutecznie paraliżowałaby próby zalegalizowania i rozbudowy własnych struktur organizacyjnych. Zamierzano przy tym wykorzystać rozbieżności między Łemkami a działaczami UTSK. Plany te zdezaktualizowały się z chwilą, gdy Paweł Stefanowski i Jarosław Zwoliński opuścili województwo zielonogórskie. Tym samym, jak stwierdzono, „upadły tendencje do stworzenia odrębnej organizacji łemkowskiej"62.

Niektórzy wysiedleńcy próbowali przełamać opór władz w kwestii powrotów, deklarując wolę założenia spółdzielni produkcyjnych. W maju 1959 r. mieszkańcy Torzymia (powiat sulęciński) Stefan Merena i Andrzej Zwoliński wystosowali petycje do ministerstwa rolnictwa, Rady Państwa i PWRN w Zielonej Górze, w których prosząc o możliwość odzyskania dawnych posiadłości w powiecie nowosądeckim, zgłosili gotowość do stworzenia tam gospodarstw kolektywnych. Jednak władze odrzuciły ich prośbę, a referat SB w Sulęcinie założył na wymienionych inicjatorów sprawę ewidencyjno-obserwacyjną krypt. „Florynka” ${ }^{63}$.

${ }^{62}$ Ibidem, Analiza kontrwywiadowcza terenu województwa zielonogórskiego po zagadnieniu mniejszości ukraińskiej, 18 VIII 1958, k. 6-23; ibidem, Sprawozdanie Grupy III Wydziału III KW MO w Zielonej Górze po zagadnieniu nacjonalizmu ukraińskiego za III kwartał 1959 r., 25 IX 1959, k. 272.

${ }^{63}$ AIPN Po, 0038/27, t. 18, Pismo zastępcy komendanta powiatowego MO ds. Bezpieczeństwa do naczelnika Wydziału III KW MO w Zielonej Górze, 16 XII 1959, k. 58-59; AIPN Po, 0038/27, t. 4, Analiza polityczna materiałów po zagadnieniu nacjonalizmu ukraińskiego za rok 1959, 15 XII 1959, k. 168. 
PWRN in Zielona Góra, consisting of current informing the institutions about disturbing phenomena in the Ukrainian environment, probably inspiring some preventive measures (such as political-warnings talks) as well, contributed to curtailing the activity of the Ukrainian Society. It was also suggested that beneficial situation from the point of view of the authorities was that competition between the UTSK activists and "the group regarded as the Lemkos not associated with the Society". It was intended to provide agent-operational actions, not clearly defined, to "neutralize nationalist activities"64. From the end of the 1950s local units of UTSK in Zielona Góra were subject to the close supervision of "security", administration and party apparatus. In order to prevent the entry of the "nationalist elements" into the authorities of the Society, the campaign of reporting and election campaigns was controlled. The political candidates who were politically dangerous were eliminated from the list of candidates for national congress$\mathrm{es}^{65}$. In the documents of January 1960, the "headquarters" was informed in an alarming tone that the election of delegates from the Zielona Góra province was not in accordance with the rules in force. Most of

64 AINR Po, 0038/27, vol. 1, Analiza kontrwywiadowcza terenu województwa zielonogórskiego po zagadnieniu nacjonalizmu ukraińskiego, 18 VIII 1958 , c. 23.

65 AINR Po, 0038/27, vol. 5, Notatka służbowa $\mathrm{z}$ rozmowy $\mathrm{z}$ kierownikiem WSW PPRN w Nowej Soli, 17 XI 1959, c. 53; AINR Po, 0038/27, vol. 1, Pismo naczelnika Wydziału III KW MO w Zielonej Górze do zastępców komendantów powiatowych MO ds. bezpieczeństwa, 17 XI 1960, c. 521.
W latach 1957-1959 priorytetowym zadaniem dla SB, w ramach forsowanego przez ekipę Władysława Gomułki stabilizowania systemu politycznego, było zapewnienie pełnej kontroli nad organizacjami społecznymi i politycznymi, które na fali „odwilży” politycznej uzyskały pewną samodzielność. Należało do nich UTSK oraz zalążek organizacji łemkowskiej. W planach operacyjnych Wydziału III KW MO w Zielonej Górze z połowy 1958 r. uwzględniono rozpoznanie: „tendencji nacjonalistycznych wypływających od działaczy UTSK i łemkowskich”, rozdźwięku między ukraińskim Towarzystwem a grupą łemkowską oraz skali oddziaływania ukraińskiej emigracji politycznej na wymienione struktury. Ścisłe współdziałanie z KW PZPR i PWRN w Zielonej Górze, polegające na bieżącym informowaniu wymienionych instancji o niepokojących zjawiskach w środowisku ukraińskim, a zapewne też inspirowaniu niektórych posunięć o charakterze prewencyjnym (m.in. rozmów polityczno-ostrzegawczych), przyczyniło się do ograniczenia działalności ukraińskiego Towarzystwa. Sugerowano też, że korzystną z punktu widzenia władz okolicznością była rywalizacja między aktywem UTSK a „grupą uchodzącą za Łemków niezwiązanych z Towarzystwem”. Zamierzano ją wykorzystać do realizacji bliżej niesprecyzowanych czynności agenturalno-operacyjnych, zapewniających „neutralizację działalności nacjonalistycznej"64. Od końca lat 50. koła

64 AIPN Po, 0038/27, t. 1, Analiza kontrwywiadowcza terenu województwa zielonogórskiego po zagadnieniu nacjonalizmu ukraińskiego, 18 VIII 1958, k. 23. 
the 13 representatives were described as "supporters of Ukrainian nationalism"66. Whenever possible, the measures leading to the administrative liquidation of circles and county boards were stimulated ${ }^{67}$. Any increase in cultural activity in the Ukrainian environment, caused even by celebrations of the 10th anniversary of the establishment of the UTSK (1966), was regarded as a serious operational challenge, requiring proper preparation and protection from the three interrelated segments of local authority ${ }^{68}$.

Regardless of ensuring "proper" functioning of the UTSK, the religion life of Ukrainians was subject to permanent surveillance ${ }^{69}$. The Orthodox parishes estab-

66 AINR Po, 0038/27, vol. 1, Sprawozdanie Grupy III Wydziału III KW MO w Zielonej Górze po zagadnieniu nacjonalizmu ukraińskiego i białoruskiego za IV kwartał 1959 r., 5 I 1960, c. 345.

67 The irritation of local authorities was risen, among others, by the activity of Grzegorz Majczak, head of the ZP UTSK in Nowa Sól, who on the basis of the agent's message was accused of conducting illegal money collections and about 100 self-made applications for assistance for Ukrainian farmers. His failure to provide documentation of the activity of the Society's unit in Nowa Sól was eagerly used for its administrative liquidation "as in fact nonexistent” (AINR Po, 0038/27, vol. 5, Pismo zastępcy komendanta powiatowego MO ds. bezpieczeństwa w Nowej Soli do naczelnika Wydziału III w Zielonej Górze, 4 I 1961, c. 145).

68 AINR, 0038/27, vol. 3, Notatka służbowa, 17 I 1966, c. 325; ibidem, Notatka służbowa, 28 I 1966, c. 326.

69 Founded in August 1958, the Zielona Góra deanery of the Orthodox diocese of Wroclaw-Szczecin included parishes in: Buczyna, Brzoza, Kożuchów, Lipiny, Leszno Górne, Ługach, Przemków, Szprotawa, Torzym, Zielona Góra i Polkowice. Functioning in the same time The Eastern Rite Catholics parishes were located in Zielona Góra, Międzyrzecz, Skwierzyna, Dobiegniew and Strzelce Krajeńskie terenowe UTSK w Zielonogórskiem podlegały ścisłemu nadzorowi „bezpieki”, administracji i aparatu partyjnego. Aby uniemożliwić wejście do władz Towarzystwa „elementów nacjonalistycznych”, sterowano przebiegiem kampanii sprawozdawczo-wyborczych. Z list kandydatów na zjazdy krajowe eliminowano osoby budzące wątpliwości natury politycznej ${ }^{65}$. W dokumentach ze stycznia 1960 r. w alarmistycznym tonie informowano „centralę,, że wybory delegatów z województwa zielonogórskiego odbyły się niezgodnie z obowiązującymi zasadami. Większość spośród 13 reprezentantów określono jako „Zwolenników nacjonalizmu ukraińskiego"66. Tam, gdzie było to możliwe, stymulowano działania prowadzące do administracyjnej likwidacji kół i zarządów powiatowych $^{67}$. Każdorazowy wzrost aktywności kulturalnej w środowisku ukraińskim, spowodowany choćby obchodami X rocznicy

65 AIPN Po, 0038/27, t. 5, Notatka służbowa $\mathrm{z}$ rozmowy z kierownikiem WSW PPRN w Nowej Soli, 17 XI 1959, k. 53; AIPN Po, 0038/27, t. 1, Pismo naczelnika Wydziału III KW MO w Zielonej Górze do zastępców komendantów powiatowych MO ds. bezpieczeństwa, 17 XI 1960, k. 521.

66 AIPN Po, 0038/27, t. 1, Sprawozdanie Grupy III Wydziału III KW MO w Zielonej Górze po zagadnieniu nacjonalizmu ukraińskiego i białoruskiego za IV kwartał 1959 r., 5 I 1960, k. 345.

67 Irytację lokalnych władz budziła m.in. działalność Grzegorza Majczaka, kierującego ZP UTSK w Nowej Soli, któremu na podstawie wiadomości agenturalnych zarzucano prowadzenie nielegalnych zbiórek pieniędzy oraz własnoręczne sporządzenie ok. 100 wniosków o zapomogi dla rolników ukraińskich. Niedostarczenie przezeń na czas dokumentacji obrazującej działalność nowosolskiego ogniwa Towarzystwa, skwapliwie wykorzystano do jego administracyjnej likwidacji ,jako faktycznie nie istniejącego" (AIPN Po, 0038/27, t. 5, Pismo zastępcy komendanta powiatowego MO ds. bezpieczeństwa w Nowej Soli do naczelnika Wydziału III w Zielonej Górze, 4 I 1961, k. 145). 
lished in Ziemia Lubuska and the semilegal institutions of the Greek Catholic Church were seen exclusively as a means of stabilizing the displaced people ${ }^{70}$. All activities that strengthened the parishioners' national identity, led to conflicts with the authorities and the Polish environment, and fostered faith in returning to their homeland were fought off ${ }^{71}$. Priests were under operational control ${ }^{72}$ and more or less successful attempts to recruit them were made ${ }^{73}$.

In June 1961, officers of Group III of the Division III of KW MO in Zielona Góra conducted seven issues "as Ukrainian problem" (1 case of operational observation, 1 case of operational investigation and 5 cases of operational verification), while their colleagues from the

(See: S. Dudra, Poza mała ojczyzną..., pp. 130-151 and 163-169; A. Chabasińska, Kościół prawosławny na Ziemi Lubuskiej po II wojnie światowej, "Studia Lubuskie" 2010, vol. 6, pp. 379-402).

70 In February 1961 during the preventivewarning conversation, an Orthodox priest from Przemków was forced to dissolve "doubts about the Recovered Territories" during the forthcoming sermon (AINR Po, 0038/27, vol. 14, Informacja dotycząca zagadnienia nacjonalizmu ukraińskiego za I kwartał, 6 III 1961, c. 151).

71 AINR Po, 0038/27, vol. 5, Uzupełnienie do kontrwywiadowczej charakterystyki po zagadnieniu nacjonalizmu ukraińskiego, 31 XII 1960, c. 40.

72 There were cases codenamed "Wiara" (Fr. Jarosław Wodonos), "Rep” (set for Fr Grzegorz Fedoryszak) and finally surveillance "Alpa" concerning Wlodzimierz Hajdukiewicz. Together with the units of the SB from the Koszalin province they also participated in the surveillance of Fr. Teodor Markow.

73 The case of Secret Collaborator pseudonym "Homo" is worth noting - Fr. Włodzimierz Kochan, the parish priest of the Orthodox parish of Ługi and Brzoza, cooperating with the SB in 1959-1981. powołania UTSK (1966), był traktowany jako poważne wyzwanie natury operacyjnej, wymagające odpowiedniego przygotowania i zabezpieczenia ze strony trzech współdziałających ze sobą segmentów lokalnej władzy ${ }^{68}$.

Niezależnie od zapewnienia „prawidłowego" funkcjonowania UTSK permanentną inwigilacją objęto życie wyznaniowe Ukraińców ${ }^{69}$. Powołane na Ziemi Lubuskiej oficjalne parafie prawosławne i na poły legalne placówki duszpasterstwa greckokatolickiego postrzegano wyłącznie jako środek do ustabilizowania przesiedleńców ${ }^{70}$. Ostro zwalczano wszelkie działania, które umacniały odrębność narodową parafian, prowadziły do konfliktów $\mathrm{z}$ władzami i polskim otoczeniem oraz podsycały wiarę w powrót w ojczyste strony ${ }^{71}$. Kapła-

68 AIPN, 0038/27, t. 3, Notatka służbowa, 17 I 1966, k. 325; ibidem, Notatka służbowa, 28 I 1966, k. 326.

69 Powołany w sierpniu 1958 r. dekanat zielonogórski prawosławnej diecezji wrocławsko-szczecińskiej obejmował parafie w: Buczynie, Brzozie, Kożuchowie, Lipinach, Lesznie Górnym, Ługach, Przemkowie, Szprotawie, Torzymiu, Zielonej Górze i Polkowicach. Działajace w podobnym czasie placówki duszpasterskie katolików obrządku wschodniego ulokowano w Zielonej Górze, Międzyrzeczu, Skwierzynie, Dobiegniewie i Strzelcach Krajeńskich (Na ten temat zob. S. Dudra, Poza mała ojczyzna. Łemkowie na Ziemi lubuskiej, Wrocław 2008, s. 130151 oraz 163-169; A. Chabasińska, Kościół prawosławny na Ziemi Lubuskiej po II wojnie światowej, „Studia Lubuskie” 2010, t. 6, s. 379-402).

70 W lutym 1961 r. podczas rozmowy profilaktyczno-ostrzegawczej zmuszono księdza prawosławnego z Przemkowa, aby ten podczas najbliższego kazania rozwiał „wątpliwości co do Ziem Odzyskanych” (AIPN Po, 0038/27, t. 14, Informacja dotycząca zagadnienia nacjonalizmu ukraińskiego za I kwartał, 6 III 1961, k. 151).

71 AIPN Po, 0038/27, t. 5, Uzupełnienie do kontrwywiadowczej charakterystyki po zagadnieniu nacjonalizmu ukraińskiego, 31 XII 1960, k. 40. 
county units had totally 28 cases, of which 11 cases of operational observation and 17 cases of operational verification ${ }^{74}$. Two years later, 36 cases of operational observation were reported together, of which "with nationalist elements" $20^{75}$. Data from 1963 testify about the stabilization of the situation in the Ukrainian environment. The actions taken by SB in that year took the form of preventive operational control. It was an element of comprehensive monitoring of social processes occurring among the Ukrainian population. Based on the information of the agents and employees of the administration, the attitude of Ukrainians to the most important events in national and international politics, the degree of integration with the Polish environment, the pattern of cultural separateness, changes in the structure of employment and participation in local authorities, licensed social and political organizations were examined. At least twice, in 1966 and 1970, SB officers "for the accurate diagnosis of the political and operational situation in the Ukrainian nationalist community" conducted sociometrical studies which covered for the first time 180, and for the second 75 influential people, associated formerly with the underground or immigrant activists, UTSK and church institutions ${ }^{76}$. Based on the results, the scale

${ }^{74}$ AINR Po, 0038/27, vol. 2, Sprawozdanie Grupy III po zagadnieniu nacjonalizmu ukraińskiego za IV kwartał 1961, 29 XII 1961, c. 261.

75 AINR Po, 0038/27, vol. 3, Sprawozdanie Grupy III Wydziału III KW MO w Zielonej Górze za 1963 r., 13 I 1964, c. 203-210.

${ }^{76}$ Ibidem, Notatka informacyjna dotycząca zagadnienia mniejszości narodowych, 8 X 1966 r., nów otoczono kontrolą operacyjną ${ }^{72}$ i podejmowano mniej lub bardziej udane próby werbunku ${ }^{73}$.

W czerwcu $1961 \mathrm{r}$. funkcjonariusze Grupy III Wydziału III KW MO w Zielonej Górze „po zagadnieniu ukraińskim” prowadzili 7 rozpracowań (1 sprawę operacyjnej obserwacji, 1 sprawę operacyjnego rozpracowania i 5 spraw operacyjnego sprawdzenia), a ich koledzy z jednostek powiatowych łącznie 28 spraw, $\mathrm{z}$ tego 11 spraw operacyjnej obserwacji i 17 spraw operacyjnego sprawdzenia ${ }^{74}$. Dwa lata później wykazano razem 36 spraw operacyjnej obserwacji, z tego o ,zabarwieniu nacjonalistycznym" $20^{75}$. Dane z 1963 r. świadczą o stabilizacji sytuacji w środowisku ukraińskim. Podejmowane od tego roku przez SB działania przybrały charakter profilaktycznej kontroli operacyjnej. Był to element kompleksowego monitorowania procesów społecznych zachodzących wśród ludności ukraińskiej. Opierając się na informacjach agentury i pracowników administracji, badano stosunek Ukraińców do najważniejszych wydarzeń w polityce krajowej i międzynarodowej, stopień integracji z polskim

72 Były to sprawy o kryptonimach „Wiara” (dot. ks. Jarosława Wodonosa), „Rep” (założona na ks. Grzegorza Fedoryszaka) i wreszcie rozpracowanie „Alpa” dotyczące ks. Włodzimierza Hajdukiewicza. Wspólnie z jednostkami SB z województwa koszalińskiego brano też udział w inwigilacji ks. Teodora Markowa.

73 Na wymienienie zasługuje tu przypadek TW ps. „Homo” - ks. Włodzimierza Kochana, proboszcza parafii prawosławnych Ługi i Brzoza, współpracującego z SB w latach 1959-1981.

74 AIPN Po, 0038/27, t. 2, Sprawozdanie Grupy III po zagadnieniu nacjonalizmu ukraińskiego za IV kwartał 1961, 29 XII 1961, k. 261.

75 AIPN Po, 0038/27, t. 3, Sprawozdanie Grupy III Wydziału III KW MO w Zielonej Górze za 1963 r., 13 I 1964, k. 203-210. 
of the potential threat from the Ukrainian environment was diagnosed and conclusions were drawn for further operational work.

At the turn of the fifties and sixties of the last century the government's anxiety aroused because of the almost uncontrollable contacts between citizens of the People's Republic of Poland and foreigners. They were also maintained by Polish Ukrainians, whose millions of compatriots the fate spread around the world, on both sides of the "iron curtain". It was suggested that about 1,700 representatives of the Ukrainian minority in Zielona Góra corresponded with their kinsmen in the West. The vast majority were family and social contacts, which the authorities were willing to tolerate. However, there was a disapproval of any attempt to arbitrarily communicate with Ukrainian and Lemko exile organizations. It was considered unacceptable to receive the press and all other publications from them, or, worse yet, material help, which escaped rigorous fiscal regulations. Conveying to the West any information critical of the situation in Poland and the USSR was considered an act of disloyalty. In the Zielona Gora province in the years 1957-1960 at least 60 people were reported as corresponding with the so-called nationalist centers. The local security apparatus was tasked with a detailed diagnosis of this issue. The most valuable contacts were intended to be taken over and used for their own operational purposes (this

c. 334; AINR, 0236/95/3, Informacje Wydziału III KW MO w Zielonej Górze, [sierpień 1970], c. 86-94. otoczeniem, formy podtrzymywania odrębności kulturowej, zmiany w strukturze zatrudnienia oraz uczestnictwo w lokalnych władzach, koncesjonowanych organizacjach społecznych i politycznych. Przynajmniej dwukrotnie, w latach 1966 i 1970, funkcjonariusze SB „dla dokładnego rozpoznania sytuacji politycznej i operacyjnej w środowisku nacjonalistów ukraińskich" przeprowadzili badania socjometryczne, którymi objęto za pierwszym razem 180, a za drugim 75 wpływowych osób, związanych w przeszłości z podziemiem lub aktywem emigracyjnym, UTSK i instytucjami kościelnymi ${ }^{76}$. Na podstawie wyników diagnozowano skalę potencjalnego zagrożenia ze strony środowiska ukraińskiego i formułowano wnioski do dalszej pracy operacyjnej.

Na przełomie lat 50. i 60. ubiegłego wieku niepokój władz wzbudziły wymykające się kontroli kontakty obywateli PRL z cudzoziemcami. Utrzymywali je także polscy Ukraińcy, których miliony rodaków los rozsiał po całym świecie, po obu stronach „żelaznej kurtyny”. Sugerowano, że ok. 1700 przedstawicieli mniejszości ukraińskiej w Zielonogórskiem korespondowało $\mathrm{z}$ pobratymcami na Zachodzie. $\mathrm{W}$ olbrzymiej większości były to kontakty rodzinne i towarzyskie, które władze skłonne były tolerować. Wyrażano jednak dezaprobatę wobec wszelkich prób samowolnego komunikowania się z ukraińskimi i łemkowskimi organizacjami emigracyjnymi. Za niedopuszczalne uznano odbieranie od

76 Ibidem, Notatka informacyjna dotycząca zagadnienia mniejszości narodowych, 8 X 1966 r., k. 334; AIPN, 0236/95/3, Informacje Wydziału III KW MO w Zielonej Górze [sierpień 1970], k. 86-94. 
was the surveillance of immigrant organizations, disinformation and spread negative opinion about them among people), while others were to be "cut" once and for all. Let us show that in 1968 Group III of the Division III of KW MO in Zielona Gora informed about only 7 registered correspondence contacts of citizens of Ziemia Lubuska with immigrant organizations, from which up to 5 cases were inspired by SB secret collaborators ${ }^{77}$.

The greatest hope for a spectacular success was the operational game with the USbased Foreign Corps of Ukraine's Central Liberation Council (ZP UHWR). As part of the operational checking case of the codename "List" secret collaborator (SC) pseud. "Krakus" corresponded with Stefan Sokolak of the Press and Propaganda Department of the UHWR in Chicago, who reported on his eight-year stay in prison and allegedly "persistence with patriotic beliefs". Unaware Sokolak, in addition to the letters, sent the informant $\$ 10$, clothing parcels, and a propaganda brochure asking to send it to the inhabitants of the Ukrainian SSR. The officers of the Division III of KW MO in Zielona Góra and the collaborating representatives of Soviet counterintelligence from the unit in Szprotawa faced a chance to organize a controlled channel of sending nationalist literature to the USSR. With the full conspiracy ("without mutual deciphering"),

77 AINR Po, 060/45, vol. 43, Sprawozdanie z pracy Wydziału II KW MO w Zielonej Górze za rok 1968, 9 I 1969, c. 18 and 44. nich prasy i wszelkich innych publikacji czy też, co gorsza, pomocy materialnej wymykającej się rygorystycznym przepisom skarbowym. Za akt nielojalności uznawano przekazywanie na Zachód jakichkolwiek informacji stawiających w krytycznym świetle sytuację w Polsce i ZSRR. W województwie zielonogórskim w latach 1957-1960 naliczono przynajmniej 60 osób, które korespondowały z tzw. ośrodkami nacjonalistycznymi. Miejscowy aparat bezpieczeństwa otrzymał zadanie szczegółowego rozpoznania tego zagadnienia. Najcenniejsze kontakty zamierzano przejąć i wykorzystać do własnych celów operacyjnych (chodziło tu o rozpracowanie organizacji emigracyjnych, dezinformowanie ich i skompromitowanie przed opinią publiczną), inne zaś miały być raz na zawsze „przecięte”. O skuteczności podjętych działań niech świadczy to, że w 1968 r. Grupa III Wydziału III KW MO w Zielonej Górze informowała o zaledwie 7 zarejestrowanych kontaktach korespondencyjnych mieszkańców Ziemi Lubuskiej $z$ organizacjami emigracyjnymi, $\mathrm{z}$ tego aż w 5 przypadkach nawiązali je inspirowani przez SB tajni współpracownicy ${ }^{77}$.

Największe nadzieje na spektakularny sukces rokowała gra operacyjna $\mathrm{z}$ amerykańskim ogniwem Zagranicznego Przedstawicielstwa Ukraińskiej Głównej Rady Wyzwoleńczej (ZP UHWR). W ramach sprawy operacyjnego sprawdzenia krypt. „List” TW ps. „Krakus” korespondował ze Stefanem Sokolakiem z Wydziału Prasy i Propagandy ZP UHWR w Chicago,

77 AIPN Po, 060/45, t. 43, Sprawozdanie z pracy Wydziału II KW MO w Zielonej Górze za rok 1968, 9 I 1969, k. 18 i 44. 
Krakus was contacted by the KGB agent "Dnieprowski", a soldier serving in Poland. It was initially agreed that going on a leave the soldier would take packages for "Krakus's" relatives for a small fee. At the same time, the SB collaborant was to inform Sokolak in a letter that there was a possibility of "using this transit route for other purposes". It was expected that UHWR would be provoked in this way to use the new "communication channel"78. Unfortunately, there is no information about the finale of the case.

A few years later, SC pseud. "Gerwazy" (Stefan Semeniuk), was selected for the surveillance of the Ukrainian organizations operating on the British Isles, primarily the Union of Ukrainians in the UK (SUB) and the Organization of Ukrainian Women (OUŻ). And this time the matter was also implemented in close agreement with the Soviet security apparatus. In June 1968, a suitably prepared secret agent held a talk with a representative of the women's organization in Poznań. He obtained a lot of valuable information for the SB, decribing cooperation of the Ukrainian diaspora with "Zionist centers". An initial plan of sending "Gerwazy" for a temporary stay in England was outlined, where,

78 AINR Po, 0038/27, vol. 1, Perspektywiczny plan pracy Grupy III Wydziału III KW MO w Zielonej Górze po zagadnieniu nacjonalizmu ukraińskiego, 1 IX 1962, c. 70; AINR Po, 0038/27, vol. 3, Raport $\mathrm{z}$ kontroli Grupy III Wydziału III KW MO w Zielonej Górze przeprowadzonej przez pracowników Wydziału III Departamentu III MSW w dniach 7-11 V 1963 po zagadnieniu nacjonalizmu ukraińskiego i białoruskiego, $10 \mathrm{~V}$ 1963, c. 71. którego informował o ośmioletnim pobycie w więzieniu i rzekomym ,trwaniu przy patriotycznych przekonaniach". Nieświadomy Sokolak, prócz listów, przesłał konfidentowi 10 USD, paczki z odzieżą oraz broszurę propagandową z prośbą o przesłanie jej mieszkańcom Ukraińskiej SRR. Przed funkcjonariuszami Wydziału III KW MO w Zielonej Górze i współdziałającymi z nimi przedstawicielami radzieckiego kontrwywiadu z jednostki w Szprotawie otwierała się szansa zorganizowania kontrolowanego kanału przesyłania literatury nacjonalistycznej do ZSRR. Przy zachowaniu pełnej konspiracji („,bez wzajemnego rozszyfrowania się”) skontaktowano „Krakusa” z agentem KGB „Dnieprowskim”, żołnierzem odbywającym służbę w Polsce. Wstępnie uzgodniono, że wojskowy, jadąc na urlop do kraju, za drobną opłatą weźmie ze sobą paczki przeznaczone dla krewnych „Krakusa”. Równocześnie współpracownik SB miał listownie oznajmić Sokolakowi, że zaistniała możliwość „wykorzystania tej drogi przesyłkowej również do innych celów". Spodziewano się, że w ten sposób sprowokuje się UHWR do korzystania z nowego „kanału łączności”78. Niestety brak informacji o finale sprawy.

Kilka lat później do rozpracowania ukraińskich organizacji działających na Wyspach Brytyjskich, przede wszystkim Związku Ukraińców w Wielkiej Bryta-

78 AIPN Po, 0038/27, t. 1, Perspektywiczny plan pracy Grupy III Wydziału III KW MO w Zielonej Górze po zagadnieniu nacjonalizmu ukraińskiego, 1 IX 1962, k. 70; AIPN Po, 0038/27, t. 3, Raport z kontroli Grupy III Wydziału III KW MO w Zielonej Górze przeprowadzonej przez pracowników Wydziału III Departamentu III MSW w dniach 7-11 V 1963 po zagadnieniu nacjonalizmu ukraińskiego i białoruskiego, 10 V 1963, k. 71. 
thanks to the recommendation of friends, he was to reach the Anti-Bolshevik Block of Nations ${ }^{79}$. In talks with immigrants, he offered to provide financial assistance to selected people in the USRR (including the widow of Roman Szuchewycz, former UPA commander). He also pointed to "trusted people" who were allegedly capable of "conducting organizational activities". In fact, they were KGB agents ${ }^{80}$. The case of "Gerwazy" was one of the elements of the great operation of the communist security apparatus, lasting nearly 30 years (until September 1988), targeted at structures of the emigration Bandera's organization. The Soviet documents called it "Boomerang" and its Polish counterpart was codenamed "Centrala"

At least from November 1959 SB in Zielona Góra tried to control the operations of the Defense of Lemkivshchyna Organization (OOŁ), which was demanding from the Polish authorities to liquidate the effects of the "Vistula" operation and, if possible, to materially support its supporters in Poland. The aid was addressed to the Lemkos emphasizing their belonging to the Ukrainian people, who decided to return home or started education at the academic level. After initial exploratory activities consisting in establishing the circle of readers of press issued by $\mathrm{OO}$

79 AINR Po, 060/97/8, Sprawozdanie Wydziału III KW MO w Zielonej Górze z pracy operacyjnej za rok 1968, c. 19.

80 AINR, 0296/138, vol. 4, Notatka ze spotkania w Kijowie w dniach 5 VI-11 VI 1967, c. 188. 268-269.

${ }^{81}$ See: I. Hałagida, Prowokacja “Zenona"..., pp nii (SUB) i Organizacji Ukraińskich Kobiet (OUŻ), wytypowano TW ps. „Gerwazy” (Stefan Semeniuk). I tym razem sprawę realizowano $\mathrm{w}$ ścisłym porozumieniu $\mathrm{z}$ radzieckim aparatem bezpieczeństwa. W czerwcu 1968 r. odpowiednio przygotowany konfident odbył w Poznaniu rozmowę z przedstawicielką wymienionej organizacji kobiecej. Uzyskał wiele cennych dla SB informacji opisujących m.in. współpracę ukraińskiej diaspory z „ośrodkami syjonistycznymi”. Nakreślono wstępny plan wysłania "Gerwazego" na pobyt czasowy do Anglii, gdzie dzięki rekomendacji znajomych miał dotrzeć do działaczy Antybolszewickiego Bloku Narodów ${ }^{79}$. $\mathrm{W}$ rozmowach $\mathrm{z}$ emigrantami oferował przekazywanie pomocy materialnej wybranym osobom w USRR (m.in. wdowie po Romanie Szuchewyczu, dawnym dowódcy UPA). Miał też wskazywać „,zaufane osoby”, jakoby zdolne do "prowadzenia działalności organizacyjnej”. Rzeczywiście byli to agenci KGB ${ }^{80}$. Przypadek "Gerwazego" był jednym z elementów trwającej niemal trzydzieści lat (aż do września 1988 r.) wielkiej, wymierzonej w emigracyjne struktury banderowskie, operacji komunistycznego aparatu bezpieczeństwa. $\mathrm{W}$ dokumentach radzieckich określano ją mianem „Bumerang”, a jej polski odpowiednik nosił kryptonim „Centrala”81.

Przynajmniej od listopada 1959 r. zielonogórska SB usiłowała kontrolować po-

79 AIPN Po, 060/97/8, Sprawozdanie Wydziału III KW MO w Zielonej Górze z pracy operacyjnej za rok 1968, k. 19.

80 AIPN, 0296/138, t. 4, Notatka ze spotkania w Kijowie w dniach 5 VI-11 VI 1967, k. 188.

81 Zob. I. Hałagida, Prowokacja „Zenona”..., s. 268-269. 
("Lemkiwski Wisti”"82) and recipients and distributors of material aid (so called decimals), SB started picking out among them agents useful for conducting offensive operations against Lemko emigration ${ }^{83}$. In May 1960, they chose Michał Kowalski, a well-known social activist, until recently secretary of the UTSK Regional Executive Board in Zielona Góra, "figurant" of the case codename "Próba". However, he rejected the proposed cooperation with the "security" so the SB officers adopted a second scenario for actions. Its culmination was the trial of political character. Under the new case codename "Kontakt", operational and repressive undertakings numerous revisions, hearings, preventive warnings, inspection of correspondence, and finally extremely severe, even for draconian legislation at that time, the sentence on Kowalski (6 years), effectively discouraged many Ukrainians in Zielona Góra not only from contacts with the diaspora, but also from any social activity. People who had the newspaper "Lemkivski Wisti" burnt it down for fear of unpleasant consequences. One of the inhabitants of Lipki Wielkie near Gorzów was

82 On average 5-8 people in particular counties received "Lemkiwski Wisti", mostly in the form of slips attached to parcels. In at least two cases (it was suspected that there were more), sending information from Zielona Góra to the editorial office of that magazine was uncovered (AINR Po, 0038/27, vol. 1, Notatka informacyjna dotycząca nacjonalizmu ukraińskiego na terenie województwa zielonogórskiego wg danych statystycznych, 21 XII 1960, c. 532-534).

83 Ibidem, Pismo zastępcy naczelnika Wydziału III Departamentu III MSW do naczelnika Wydziału III KW MO w Zielonej Górze, 25 XI 1959, c. 298. czynania Organizacji Obrony Łemkowszczyzny (OOŁ), która stanowczo domagała się od polskich władz likwidacji skutków akcji „Wisła”, a także w miarę możliwości wspierała materialnie swoich sympatyków w Polsce. Pomoc adresowano do Łemków podkreślających przynależność do narodu ukraińskiego, którzy decydowali się na powrót $\mathrm{w}$ ojczyste strony lub podejmowali edukację na szczeblu akademickim. SB po wstępnych działaniach rozpoznawczych polegających na ustaleniu kręgu czytelników prasy wydawanej przez OOŁ („Łemkiwski Wisti” ${ }^{2}$ ) oraz odbiorców i dystrybutorów pomocy materialnej (tzw. dziesiętników) przystąpiła do typowania wśród nich agentury przydatnej do prowadzenia ofensywnych działań operacyjnych wobec łemkowskiej emigracji83. W maju 1960 r. wybór padł na Michała Kowalskiego, znanego działacza społecznego, do niedawna sekretarza Zarządu Wojewódzkiego UTSK w Zielonej Górze, „figuranta” sprawy krypt. „Próba”. Jednak odrzucenie przez wymienionego propozycji współpracy z „bezpieką” skutkowało przyjęciem przez funkcjonariuszy SB drugiego scenariusza działań. Jego zwieńczeniem było wytoczenie procesu o charakterze politycznym. Podejmowane w ramach

82 „Łemkiwski Wisti” otrzymywało przeciętnie 5-8 osób w poszczególnych powiatach, najczęściej w formie wycinków dołączanych do paczek. Przynajmniej w dwóch przypadkach (podejrzewano, że było ich więcej) ustalono przesyłanie informacji $\mathrm{z}$ terenu zielonogórskiego do redakcji tegoż pisma (AIPN Po, 0038/27, t. 1, Notatka informacyjna dotycząca nacjonalizmu ukraińskiego na terenie województwa zielonogórskiego wg danych statystycznych, 21 XII 1960, k. 532-534).

83 Ibidem, Pismo zastępcy naczelnika Wydziału III Departamentu III MSW do naczelnika Wydziału III KW MO w Zielonej Górze, 25 XI 1959, k. 298. 
almost saved at the last moment from the SB provocation (sending another issue of the Lemko magazine, requisitioned by the Office "W" of the Ministry of Interior), revision and detention for 48 hours $^{84}$.

For the next few years contacts with OOŁ were maintained only by secret collaborators with the pseudonyms "Homo" and "Irek". They wrote their letters under the SB dictation and sent them to Stefan Żenecki, the organization officer and editor of "Łemkiwski Wisty" at the same time ${ }^{85}$. The confidents, at the behest of their principals, attempted, but unsuccessfully, to establish "directions of interest of the OOE [in the situation] in Poland", the national contacts of the organization and its methods of operation. The actions ended when the mentioned Żenecki interrupted the correspondence ${ }^{86}$.

At the turn of the fifties and sixties, investigative procedures were instituted to find and punish those suspected of war crimes that had evaded criminal liabili-

84 AINR Po, 0038/37, vol. 2, Notatka służbowa do sprawy operacyjnej obserwacji kryptonim "Stary", 17 VIII 1962, c. 375.

${ }^{85}$ Ibidem, Sprawozdanie Grupy III Wydziału III po zagadnieniu nacjonalizmu ukraińskiego za II kwartał 1962 r., 2 VII 1962, c. 367. Kontakty z Żeneckim były utrzymywane w ramach sprawy "Skrzynka" (AINR Po, 0038/27, vol. 3, Raport z kontroli Grupy III Wydziału III KW MO w Zielonej Górze przeprowadzony przez pracowników Wydziału III Departamentu III MSW w dniach 7-11 V 1963 po zagadnieniu nacjonalizmu ukraińskiego i białoruskiego, $10 \mathrm{~V} \mathrm{1963,} \mathrm{c.} \mathrm{76-77).}$

${ }^{86}$ AINR Sz, 0050/116/CD/1, Notatka dotycząca gry operacyjnej z redaktorem S. Żeneckim w USA przy wykorzystaniu TW “Homo”, 5 I 1966, c. 69. nowej sprawy o kryptonimie „Kontakt” przedsięwzięcia operacyjno-represyjne liczne rewizje, przesłuchania, rozmowy profilaktyczno-ostrzegawcze, perlustracje korespondencji czy wreszcie niezwykle surowy, nawet jak na ówczesne drakońskie prawodawstwo, wyrok, który zapadł w sprawie Kowalskiego (6 lat pozbawienia wolności) - skutecznie zniechęciły wielu Ukraińców w Zielonogórskiem nie tylko do kontaktów z diasporą, ale też do jakiejkolwiek działalności społecznej. Osoby, które miały gazetę „Łemkiwski Wisti”, paliły ją w obawie przed przykrymi konsekwencjami. Jeden z mieszkańców Lipek Wielkich k. Gorzowa niemal w ostatniej chwili uchronił się w ten sposób przed prowokacją SB (przesłanie kolejnego numeru łemkowskiego pisma, zarekwirowanego przez Biuro „W” MSW), rewizją i zatrzymaniem na 48 godzin $^{84}$.

Przez najbliższych kilka lat jedyne kontakty z OOŁ utrzymywali wyłącznie tajni współpracownicy o pseudonimach „Homo" i „Irek”. Ci, pisząc swe listy pod dyktando SB, wysyłali je do Stefana Żeneckiego, referenta organizacji i równocześnie redaktora "Eemkiwskich Wisty" ${ }^{\text {" }}$. Konfidenci na polecenie mocodawców próbowali, acz bezskutecznie, ustalić „kierunki

84 AIPN Po, 0038/37, t. 2, Notatka służbowa do sprawy operacyjnej obserwacji kryptonim „Stary”, 17 VIII 1962, k. 375.

${ }^{85}$ Ibidem, Sprawozdanie Grupy III Wydziału III po zagadnieniu nacjonalizmu ukraińskiego za II kwartał 1962 r., 2 VII 1962, k. 367. Kontakty z Żeneckim były utrzymywane w ramach sprawy „Skrzynka” (AIPN Po, 0038/27, t. 3, Raport z kontroli Grupy III Wydziału III KW MO w Zielonej Górze przeprowadzony przez pracowników Wydziału III Departamentu III MSW w dniach 7-11 V 1963 po zagadnieniu nacjonalizmu ukraińskiego i białoruskiego, $10 \mathrm{~V} \mathrm{1963,} \mathrm{k.} \mathrm{76-77).}$ 
ty in previous years. Already in November 1958, a list of UPA partisans from the "Lemko" tactical section was sent to the SB regional units. The SB in Zielona Góra paid special attention to 42 out of the 168 people conspirators from Gorlice, Krosno, Jasielsk and Brzoza counties ${ }^{87}$. The acceleration of the action was fueled by the Interior Ministry leadership's fear of the criminal limitation period "for the crimes committed by the reactionary underground" beginning in 1964. Initiation of proceedings against the hiding persons allowed the prosecution period to be extended for the next five years ${ }^{88}$. As a result, it was at the beginning of the sixties that spectacular cases were brought in which the last hiding OUN and UPA soldiers, or Ukrainian policemen (often under the changed surname) were identified and handed over to the justice ${ }^{89}$.

87 AINR Po, 0038/27, vol. 1, Wykaz członków poszczególnych sotni UPA z odcinka "Łemko", którzy dotychczas nie zostali aresztowani i ujawnieni, 28 XI 1958, c. 144-155; ibidem, Wykaz członków organizacji OUN-UPA z terenu powiatów gorlickiego, krośnieńskiego, jasielskiego i brzozowskiego, c. 156-159.

${ }^{88}$ Ibidem, Pismo zastępcy komendanta wojewódzkiego MO ds. bezpieczeństwa w Poznaniu płk. A. Cygańskiego do naczelników wydziałów III, Śledczego i "C" oraz zastępców komendantów powiatowych (miejskich) województwa poznańskiego, 20 XI 1963, c. 208-209.

${ }^{89}$ However, one can get the impression, at least on the basis of reading documents from the Zielonogórskie region, that the operational matters on this foundation concerning the Ukrainians were pushed to the backdrop by surveillance of Belarusians members of the Belarusian Self-Defense, soldiers of the Belarusian National Defense and policemen. zainteresowania OOŁ [sytuacją] w Polsce", krajowe kontakty organizacji i jej metody działania. Działania zakończono z chwilą, gdy wspomniany Żenecki przerwał korespondencję ${ }^{86}$.

Na przełomie lat 50. i 60 . wszczęto procedury operacyjno-śledcze mające na celu odnalezienie i ukaranie osób podejrzewanych o przestępstwa wojenne, które uniknęły w ubiegłych latach odpowiedzialności karnej. Już w listopadzie 1958 r. do jednostek wojewódzkich SB przesłano wykaz poszukiwanych partyzantów UPA z odcinka taktycznego „Łemko”. Z grona liczącego 168 osób zielonogórska SB zwróciła szczególną uwagę na 42 konspiratorów pochodzących z powiatów gorlickiego, krośnieńskiego, jasielskiego i brzozowskiego ${ }^{87}$. Na przyspieszenie działań wpłynęła obawa kierownictwa resortu spraw wewnętrznych przed rozpoczynającym się w 1964 r. okresem przedawnienia karnego „za zbrodnie popełnione przez uczestników reakcyjnego podziemia". Wszczęcie postępowania przeciwko ukrywającym się osobom pozwalało przedłużyć okres ich ścigania o następnych pięć lat ${ }^{88}$. Skutkiem tego to właśnie na początek lat 60 . przypadają

${ }^{86}$ AIPN Sz, 0050/116/CD/1, Notatka dotycząca gry operacyjnej z redaktorem S. Żeneckim w USA przy wykorzystaniu TW „Homo”, 5 I 1966, k. 69.

87 AIPN Po, 0038/27, t. 1, Wykaz członków poszczególnych sotni UPA z odcinka „Łemko”, którzy dotychczas nie zostali aresztowani i ujawnieni, $28 \mathrm{XI}$ 1958, k. 144-155; ibidem, Wykaz członków organizacji OUN-UPA z terenu powiatów gorlickiego, krośnieńskiego, jasielskiego i brzozowskiego, k. 156-159.

${ }^{88}$ Ibidem, Pismo zastępcy komendanta wojewódzkiego MO ds. bezpieczeństwa w Poznaniu płk. A. Cygańskiego do naczelników wydziałów III, Śledczego i „C” oraz zastępców komendantów powiatowych (miejskich) województwa poznańskiego, $20 \mathrm{XI}$ 1963, k. 208-209. 
Anonymous reports from "kind" friends were introduction to some cases. In March 1958 information was received about the unclear past of Peter N., former director of dairy in Żary, former chairman of the National Municipal Council (MRN) in Sulechów and former resident of PUBP in Sulechów. The unknown author announced that the mentioned person was actually called Stefan Kozioł and had been a former Ukrainian police officer and later a member of the UPA in the Tarnopol province, suspected of crimes against the Polish population. The case was intended to be clarified by confronting the suspect with witnesses from Sokołowka, Stołpin and Łopatyna ${ }^{90}$. Sometimes it was the case that the issues from this stream of operational activity had a surprising final questioning the professionalism of the police apparatus. In 1960, Jan Klepuszewski was arrested, a "figurant" of the case of operational checking codename "Zdrajca", a former Ukrainian policeman from Kiwerce in the Lutsk province, suspected of participating in the execution of persons collaborating with the Communist partisans. On 24 December of that year, after being transported to the Zielona Góra State Prosecutor's Office, he escaped in an unknown

90 The alleged former police officer was supposed to be summoned to KW MO under the guise of explaining the past abuse in the dairy company. Just in front of the entrance to the building one of the SB officers would have an "accidental" conversation with him. At the same time, the witnesses, accompanied by another security officer, would be able to see the suspect closely (AINR Po, 0038/27, vol. 2, Plan kombinacji operacyjnej do sprawy krypt. “Twardy”, 3 II 1962, c. 292-296). spektakularne sprawy, w ramach których identyfikowano i przekazywano wymiarowi sprawiedliwości ostatnich ukrywających się (często pod zmienionym nazwiskiem) działaczy OUN i żołnierzy UPA czy też policjantów ukraińskich ${ }^{89}$.

Wstępem do niektórych spraw były anonimowe donosy przekazywane przez „życzliwych” znajomych. W marcu 1958 r. odebrano informację o niejasnej przeszłości Piotra N., byłego dyrektora mleczarni w Żarach, b. przewodniczącego MRN w Sulechowie i b. rezydenta PUBP w Sulechowie. Nieznany autor zawiadamiał, że wymieniony rzeczywiście nazywał się Stefan Kozioł, był w przeszłości funkcjonariuszem policji ukraińskiej, a następnie członkiem UPA w województwie tarnopolskim, podejrzewanym o zbrodnie na ludności polskiej. Sprawę zamierzano wyjaśnić poprzez konfrontację podejrzanego ze świadkami pochodzącymi z miejscowości Sokołowka, Stołpin i Łopatyna ${ }^{90}$. Niekiedy zdarzało się, że sprawy z tego nurtu działań operacyjnych miały zaskakujący finał stawiający pod znakiem zapytania profesjonalizm aparatu policyjnego. W $1960 \mathrm{r}$.

89 Można jednak odnieść wrażenie, przynajmniej na podstawie lektury dokumentów z Zielonogórskiego, że sprawy operacyjne o tym podłożu dotyczące Ukraińców były zepchnięte na drugi plan przez rozpracowania Białorusinów - członków Białoruskiej Samoobrony, żołnierzy Białoruskiej Obrony Krajowej i policjantów.

90 Rzekomy b. policjant miał być wezwany do KW MO pod pozorem wyjaśnienia dawnych nadużyć w przedsiębiorstwie mleczarskim. Tuż przed wejściem do budynku „przypadkową” rozmowę odbyłby $\mathrm{z}$ nim jeden $\mathrm{z}$ funkcjonariuszy SB. W tym samym czasie znajdujący się w pobliżu świadkowie, w asyście kolejnego pracownika „bezpieki”, mieliby możliwość dokładnego obejrzenia podejrzanego (AIPN Po, 0038/27, t. 2, Plan kombinacji operacyjnej do sprawy krypt. „Twardy”, 3 II 1962, k. 292-296). 
direction taking advantage of the inattention of the escort ${ }^{91}$.

Finally, it is worth mentioning that the SB in Zielona Góra was temporarily involved in affairs conducted by officers from other parts of the country. In the spring of 1959 , referring to the investigative case of Iwan Szpontak ("Zalizniak"), a UPA officer, one of his former subordinates was interviewed ${ }^{92}$. A year later, when the sensational trials of Szpontak and Aleksander Duber ("Sokil") took place the SB officers were urgently instructed to find people who had collected money in the Ukrainian environment for lawyers for the accused. It was learned that the inquiries were undertaken, among others, by Grzegorz Majczak, an activist of the UTSK from the Nowy Sącz county, who collected PLN 700 allegedly "for the construction of a monument to the Ukrainian victims of the Nazi terror". Inspired by the SB, the fine of PLN 1,500 for illegal collection was imposed on them ${ }^{93}$.

As it was already signaled, in the years 1957-1965, Group V of Division II of KW MO in Zielona Góra also ran operational

91 AINR Po, 0038/27, vol. 2, Sprawozdanie Grupy III Wydziału III KW MO w Zielonej Górze po zagadnieniu nacjonalizmu ukraińskiego i białoruskiego za IV kwartał 1960 r., 4 I 1961, c. 14.

92 Ibidem, Pismo naczelnika Wydziału III KW MO w Rzeszowie do naczelnika Wydziału III KW MO w Zielonej Górze, 11 III 1959, c. 174; ibidem, Pismo naczelnika Wydziału III KW MO w Zielonej Górze do naczelnika Wydziału III KW MO w Rzeszowie, 11 V 1959, c. 175.

93 AINR Po, 0038/27, vol. 5, Sprawozdanie kwartalne za II kwartał 1960 r. po linii nacjonalizmu ukraińskiego, 28 VI 1960, c. 112. aresztowano Jana Klepuszewskiego, „,figuranta" sprawy operacyjnego sprawdzenia krypt. „Zdrajca”, w przeszłości policjanta ukraińskiego z Kiwerc w województwie łuckim, podejrzewanego o udział w egzekucjach osób współpracujących z komunistyczną partyzantką. 24 grudnia tego roku wymieniony po przewiezieniu do budynku Prokuratury Wojewódzkiej w Zielonej Górze, korzystając z nieuwagi eskorty, zbiegł w niewiadomym kierunku ${ }^{91}$.

Wreszcie warto nadmienić, że zielonogórska SB doraźnie angażowała się w sprawy prowadzone przez funkcjonariuszy z innych części kraju. Wiosną 1959 r., w nawiązaniu do prowadzonej w Rzeszowie sprawy śledczej dotyczącej Iwana Szpontaka (ps. „Zalizniak”), oficera UPA, przesłuchano jednego $\mathrm{z}$ jego dawnych podkomendnych ${ }^{92}$. Gdy rok później doszło do głośnych procesów Szpontaka i Aleksandra Dubera (ps. „Sokił”), w trybie pilnym polecono ustalić osoby, które zbierały w środowisku ukraińskim pieniądze na adwokatów dla oskarżonych. Dowiedziano się, że kwestowania podjął się m.in. Grzegorz Majczak, działacz UTSK z powiatu nowosolskiego, który zgromadził $700 \mathrm{zł}$ rzekomo „na budowę pomnika ukraińskich ofiar terroru hitlerowskiego". Z inspiracji SB karę za nielegalną zbiórkę wymie-

91 AIPN Po, 0038/27, t. 2, Sprawozdanie Grupy III Wydziału III KW MO w Zielonej Górze po zagadnieniu nacjonalizmu ukraińskiego i białoruskiego za IV kwartał 1960 r., 4 I 1961, k. 14.

92 Ibidem, Pismo naczelnika Wydziału III KW MO w Rzeszowie do naczelnika Wydziału III KW MO w Zielonej Górze, 11 III 1959, k. 174; ibidem, Pismo naczelnika Wydziału III KW MO w Zielonej Górze do naczelnika Wydziału III KW MO w Rzeszowie, 11 V 1959, k. 175. 
actions. In November 1958, they conducted 2 cases of agent checking and 1 group agent case. At the same time, county security units conducted a total of 15 counterintelligence cases, of which 13 were record and observation ones, and 2 were agent checking cases. However, it was acknowledged that, due to short working hours, poor network of agents in the field and outdated operating materials, the effects of work were unsatisfactory $y^{94}$. Her activities focused on the widely-held "connections with the Bandera and Melnyk emigration centers" ${ }^{\prime 25}$.

Among the most important investigations conducted by counterintelligence in Zielona Góra was a matter of operational observation codenamed "Grupa", in which Katarzyna and Michał Łowczanin ${ }^{96}$ and

94 AINR Po, 0038/27, vol. 1, Kontrwywiadowcza charakterystyka terenu województwa zielonogórskiego po zagadnieniu nacjonalizmu ukraińskiego, 3 XI 1958, c. 27-30.

95 AINR Po, 0038/27, vol. 2, Analiza pracy operacyjnej Grupy V Wydziału II KW MO w Zielonej Górze po zagadnieniu nacjonalizmu ukraińskiego za rok 1962, 19 XII 1962, c. 450-455.

96 Katarzyna Łowczanin, nee Dytyniak "Katia”, "Kejt" or "Katty" (born 1923). In 1944-1945 she belonged to the civilian network of the District II OUN. After the resettlement, she lived initially in the Ziemia Lubuska, later in Wroclaw. In 1952 she escaped, in fear of arrest, to the Koszalin province. There, in a bunker hidden in the woods on the border of Człuchów and Złotów counties, Michał Łowczanin "Semenka", her future husband, accompanied her. In March 1956, they were both detained by soldiers practicing on the training ground. As a result of the amnesty Katarzyna Dytyniak was relatively soon released, but "Semenko", formerly a member of SB OUN, was sentenced to four years imprisonment. In 1958, Dytyniak, having received financial support from Jan Olijar (former friend of his time in the underground) and hiring lawyers, led to the re- rzyło Kolegium Orzekające, które nałożyło grzywnę w wysokości 1500 zł ${ }^{13}$.

Jak już sygnalizowano, w latach 1957 1965 działania operacyjne wobec społeczności ukraińskiej prowadziła też Grupa V Wydziału II KW MO w Zielonej Górze. W listopadzie $1958 \mathrm{r}$. przewodziła ona 2 sprawami agenturalnego sprawdzenia i 1 sprawą agenturalną grupową. Równocześnie powiatowe referaty ds. bezpieczeństwa prowadziły łącznie 15 spraw o charakterze kontrwywiadowczym, $\mathrm{z}$ tego 13 to sprawy ewidencyjno-obserwacyjne, a 2 to sprawy agenturalnego sprawdzenia. Jednak przyznawano, że ze względu na krótki czas pracy, słabą sieć agenturalną $\mathrm{w}$ terenie i przestarzałe materiały operacyjne efekty pracy były niezadowalające ${ }^{94}$. Jej działania koncentrowały się na szeroko ujmowanych „powiązaniach z ośrodkami emigracyjnymi banderowskimi i melnykowskimi”95.

Wśród najważniejszych rozpracowań prowadzonych przez zielonogórski kontrwywiad znalazła się sprawa operacyjnej obserwacji kryptonim „Grupa”, w ramach której inwigilowano Katarzynę i Michała Łowczaninów ${ }^{96}$ oraz Piotra

93 AIPN Po, 0038/27, t. 5, Sprawozdanie kwartalne za II kwartał 1960 r. po linii nacjonalizmu ukraińskiego, 28 VI 1960, k. 112.

94 AIPN Po, 0038/27, t. 1, Kontrwywiadowcza charakterystyka terenu województwa zielonogórskiego po zagadnieniu nacjonalizmu ukraińskiego, 3 XI 1958, k. 27-30.

95 AIPN Po, 0038/27, t. 2, Analiza pracy operacyjnej Grupy V Wydziału II KW MO w Zielonej Górze po zagadnieniu nacjonalizmu ukraińskiego za rok 1962, 19 XII 1962, k. 450-455.

96 Katarzyna Łówczanin, zd. Dytyniak „Katia”, „Kejt” lub „Katty” (ur. 1923 r.). W latach 1944-1945 należała do siatki cywilnej Okręgu II OUN. Po przesiedleniu mieszkała początkowo na Ziemi Lubuskiej, później we Wrocławiu, by w 1952 r. zbiec, w obawie przed aresztowaniem, na teren województwa kosza- 
Piotr Prystupa were under surveillance, because they kept contacts with the ZP UHWR in the US, especially with Jan Olijar since 195897. "Figurants" brokered the transfer of material support and correspondence to the imprisoned OUN members $^{98}$. Because it lacked grounds to carry out subsequent arrests, secret police were preparing for two solutions. In connection with the decision of Katarzyn Eówczanin to go to the USA, they intend to give her a passport under the condition that she would agree on cooperation. At the same time, regardless of the result of talks, they planned with the help of agents (SC pseud. "Leon") spread in her environment slanders about her cooperation with "security". Similar information, supplemented with new topics (including the alleged misappropriation of money and parcels des-

vision of the sentences and thus Michał Łówczanin and another conspirator - Piotr Prystupy were released. After marriage, she settled with "Semenka" in the vicinity of Zielona Góra (I. Hałagida, Prowokacja “Zenona”..., p. 247; AINR, 00231/243/14, Plan operacyjnych przedsięwzięć do sprawy agenturalnego sprawdzenia krypt. "Grupa”, 28 I 1959, c. 21).

97 Jan (Iwan) Olijar "Kum” (born 1911) - member of UPA and emigration activist. In 1941, he was an officer of the Ukrainian police. After a three-year stay in Germany he joined the OUN and UPA, where he received the position of a regional economic advisor in the Nadrejon "Cholodnyj Jar". In 1947, he entered the US occupation zone in Germany. In 1950 he emigrated to the USA, where he settled in Cleveland. There he was associated with the Ukrainian Committee of Aid and probably the Foreign Office of the UHWR. He headed a local representative office of the Ukrainian veterans' organization. His memoirs were published (Spohad Iwana Olijara, [in:] Zakerzonnia. Spomyny wojakiw UPA, vol. 4, edit. B. Huk, Warszawa 1998, pp. 185-245).

98 They were: Zbigniew Kamiński, Eugeniusz Ptasznyk i Piotr Hojsan. (AIPN Po, 0038/27, vol. 2, Analiza pracy operacyjnej Grupy V Wydziału II KW MO w Zielonej Gorze po zagadnieniu nacjonalizmu ukraińskiego za rok 1962, 19 XII 1962, k. 450-455).
Prystupę, utrzymujących od 1958 r. kontakty z działaczami ZP UHWR w USA, przede wszystkim $z$ Janem Olijarem ${ }^{97}$. „Figuranci" pośredniczyli w przekazywaniu pomocy materialnej i korespondencji osadzonym w więzieniach członkom OUN ${ }^{98}$. W związku z tym, że brakowało podstaw do przeprowadzenia kolejnych aresztowań, funkcjonariusze SB przygotowywali

lińskiego. Tam w bunkrze ukrytym w lasach na pograniczu powiatów człuchowskiego i złotowskiego przebywała wraz z Michałem Łówczaninem „Semenką", swoim przyszłym mężem. W marcu $1956 \mathrm{r}$. oboje zostali zatrzymani przez żołnierzy ćwiczących na tamtejszym poligonie. W wyniku amnestii Katarzyna Dytyniak stosunkowo szybko wyszła na wolność, lecz „Semenko”, należący niegdyś do SB OUN, otrzymał wyrok czterech lat pozbawienia wolności. W 1958 r. Dytyniak, uzyskawszy wsparcie finansowe od Jana Olijara (dawnego znajomego z czasu działalności w podziemiu) i wynajmując adwokatów, doprowadziła do rewizji wyroków, a tym samym zwolnienia Michała Łówczanina i kolejnego konspiratora - Piotra Prystupy. Po zawarciu małżeństwa zamieszkała wraz z "Semenką" w okolicach Zielonej Góry (I. Hałagida, Prowokacja „Zenona”..., s. 247; AIPN, 00231/243/14, Plan operacyjnych przedsięwzięć do sprawy agenturalnego sprawdzenia krypt. „Grupa", 28 I 1959, k. 21).

97 Jan (Iwan) Olijar „Kum” (ur. 1911 r.) - członek UPA i działacz emigracyjny. W 1941 r. był funkcjonariuszem policji ukraińskiej. Po trzyletnim pobycie w Niemczech wstąpił do OUN i UPA, gdzie otrzymał stanowisko rejonowego referenta gospodarczego w Nadrejonie „Chołodnyj Jar”. W 1947 r. przedostał się na teren amerykańskiej strefy okupacyjnej w Niemczech. W 1950 r. wyemigrował do USA, gdzie osiadł w Cleveland. Tam związał się z Ukraińskim Komitetem Pomocy i zapewne Zagranicznym Przedstawiciestwem UHWR. Kierował lokalnym przedstawicielstwem ukraińskiej organizacji kombatanckiej. Opublikowano jego wspomnienia (Spohad Iwana Olijara, [w:] Zakerzonnia. Spomynywojakiw UPA, t. 4, red. B. Huk, Warszawa 1998, s. 185-245).

${ }_{98}$ Chodziło tu o Zbigniewa Kamińskiego, Eugeniusza Ptasznyka i Piotra Hojsana (AIPN Po, $0038 / 27$, t. 2, Analiza pracy operacyjnej Grupy V Wydziału II KW MO w Zielonej Górze po zagadnieniu nacjonalizmu ukraińskiego za rok 1962, 19 XII 1962, k. 450-455). 
tined for the prisoners), were to be written in a letter to Olijar, which they intended to give a trusted person going to the United States in the near future ${ }^{99}$.

In 1963, Group V of the Division II of KW MO in Zielona Góra invigilated a total of 8 people "worthy of interest from the point of view of the counterintelligence" who lived in the vicinity of Soviet units, corresponded with the Ukrainian nationalists in Canada and the USA. No more interesting cases were started. The task of the agents was "operational recognition of Ukrainian nationalists", the protection of the stay of foreigners of Ukrainian origin, and, in one case, the conduct of an operational game with the activist of the OUN center in Munich ${ }^{100}$.

A several fold increase in activity of counterintelligence in 1957, 1959, and $1964 / 65$, was caused by alarming information about plans of Bandera's couriers to get to Poland. In 1959, one of stages of the intriguing "Stonka" operation conducted by the SB and the KGB took place in Gorzów $^{101}$. In October of that year, Iwan Hani-

99 Ibidem, Notatka operacyjna uzupełniająca plan operacyjnych przedsięwzięć z dnia 9 X 1962 do sprawy operacyjnej.

100 AINR Po, 0038/27, vol. 2, Analiza pracy operacyjnej za okres 1 I-31 XII 1963, c. 201-202.

101 Between 1958 and 1959, delegated by the Foreign Corps of the OUN Iwan Haniak "Woron", Michał Dawydiak "Bystryj" and Piotr Lewicki "Czornota" underwent intensive training under the direction of Italian and West German instructors. Upon completion, they were provided with radios, guns, propaganda literature, maps, medications, wire cutters, cash in several currencies, ciphers, pen and ink with nice print, means for making carbon paper for secret texts, correspondent addresses, Polish and Czechoslovak blank personal papers, official stamps się do dwóch rozwiązań. W związku z powzięciem przez Katarzynę Łówczanin zamiaru wyjazdu do USA, zamierzano uzależnić wydanie jej paszportu od wyrażenia zgody na współpracę. Równocześnie, bez względu na skutek rozmowy, planowano za pomocą agentury (TW ps. „Leon”) rozsiewać w otoczeniu „figurantki” pomówienia o współpracy z „,bezpieką". Podobne informacje, uzupełnione o nowe wątki (m.in. rzekome przywłaszczanie paczek i pieniędzy przeznaczonych dla więźniów), miały znaleźć się w liście do Olijara, który zamierzano wręczyć zaufanej osobie udającej się w najbliższym czasie do Stanów Zjednoczonych ${ }^{99}$.

W 1963 r. Grupa V Wydziału II KW MO w Zielonej Górze inwigilowała łącznie 8 osób „zasługujących na zainteresowanie z punktu widzenia K[ontr]W[ywiadu]", które mieszkały w sąsiedztwie jednostek Armii Radzieckiej, korespondowały z nacjonalistami ukraińskimi w Kanadzie i USA. Nie wszczęto żadnych ciekawszych spraw. Do zadań agentury należało „operacyjne rozeznanie nacjonalistów ukraińskich", zabezpieczenie pobytu cudzoziemców pochodzenia ukraińskiego, a także, w jednym przypadku, prowadzenie gry operacyjnej z działaczem monachijskiego ośrodka OUN ${ }^{100}$.

Kilkukrotny wzrost aktywności kontrwywiadu powodowały przekazywane w latach 1957, 1959 i 1964/65 alarmujące informacje o planach przedostania się do Polski

99 Ibidem, Notatka operacyjna uzupełniająca plan operacyjnych przedsięwzięć z dnia 9 X 1962 do sprawy operacyjnej.

100 AIPN Po, 0038/27, t. 2, Analiza pracy operacyjnej za okres 1 I-31 XII 1963, k. 201-202. 
ak "Woron", OUN-B emissary, visited Halina Jaworska twice in the city on the Warta river. She was closely related to the married couple of Lidia and Osipp Tiuszko from Innsbruck, activists of the local structures of the OUN Foreign Formations in Austria. They were friends of the courier, who provided him with a recommendation letter. Haniak, plagued by health problems, remained in Gorzów until the beginning of December $1959^{102}$. On 2 December, he was detained by SB along with Jaworska. A foreign currency, organizational intelligence documents (including Bandera's letter to the "underground" commanders in Ukraine, instructions on encrypting letters, list of tasks to be performed in the USRR, map description, photography as a sign of contact with members of the network in USRR) was found at the envoy of the $\mathrm{ZCz}$ (Zakordonni Czastyny - Foreign Corps) OUN. "Worona" was immediately taken to Warsaw at the disposal of the Supreme Prosecutor's Office, which decided to imprison the detainee in Mokotów prison. Detained Jaworska handed SB all the things left in her apartment by Haniak, and

and a camera. With this equipment, they were going to have a proven route through the Czech $\mathrm{Re}$ public to Poland and from there to Ukraine. Before leaving Stepan Bandera met with couriers. Hedescribed couriers the attitude of OUN-B management to the international situation at the time. He suggested the need to target the underground network in Ukraine for intelligence activities for NATO countries. On 20 July 1959, Haniak, Dawydiak and Lewicki entered Poland (AINR, 01355/196/J, vol. 1, Dalszy ciąg szczegółowego streszczenia uzyskanych materiałów w sprawie agenturalnego rozpracowania krypt. "Stonka” według stanu na dzień 29 II 1960 r., 31 III 1960, c. 462-464).

102 Ibidem. kurierów banderowskich. W 1959 r. w Gorzowie rozegrał się jeden z etapów intrygującej operacji „Stonka” prowadzonej przez SB i $\mathrm{KGB}^{101}$. W październiku wskazanego roku Iwan Haniak „Woron”, emisariusz OUN-B, dwukrotnie odwiedził w nadwarciańskim mieście Halinę Jaworską. Była ona blisko spokrewniona $\mathrm{z}$ małżeństwem Lidii i OsypaTiuszko z Innsbrucka, działaczy lokalnych struktur Zagranicznych Formacji OUN w Austrii. Byli to znajomi kuriera, którzy wyposażyli go w list rekomendacyjny. Haniak trapiony przez problemy zdrowotne pozostał w Gorzowie do początku grudnia 1959 r. ${ }^{102} 2$ grudnia został zatrzymany przez SB wraz z kwaterującą go Jaworską. Przy wysłanniku ZCz OUN znaleziono obcą walutę, dokumenty organizacyjno-wywiadowcze ( $w$ tym list

101 W latach 1958-1959 wydelegowani przez banderowskie Zagraniczne Formacje OUN Iwan Haniak „Woron”, Michał Dawydiak „Bystryj” i Piotr Lewicki „Czornota” przeszli pod kierunkiem włoskich i zachodnioniemieckich instruktorów intensywne szkolenie wywiadowcze. Po jego ukończeniu zostali zaopatrzeni w radiostację, broń, literaturę propagandową, mapy, lekarstwa, kleszcze do cięcia drutu, gotówkę w kilku walutach, szyfry, pióra i kałamarze $\mathrm{z}$ atramentem sympatycznym, środki do sporządzania kalki do tajnopisów, adresy punktów korespondencyjnych, polskie i czechosłowackie dowody osobiste in blanco, pieczątki urzędowe i aparat fotograficzny. Z tym ekwipunkiem mieli się udać sprawdzoną trasą przez Czechy do Polski, a stamtąd na Ukrainę. Z kurierami przed wymarszem spotkał się Stepan Bandera, który opisał kurierom stosunek kierownictwa OUN-B do ówczesnej sytuacji międzynarodowej. Sugerował konieczność ukierunkowania siatki konspiracyjnej na Ukrainie na działalność wywiadowczą na rzecz państw NATO. 20 lipca 1959 r. Haniak, Dawydiak i Lewicki wkroczyli na terytorium Polski (AIPN, 01355/196/J, cz. 1, Dalszy ciąg szczegółowego streszczenia uzyskanych materiałów w sprawie agenturalnego rozpracowania krypt. „Stonka” według stanu na dzień 29 II 1960 r., 31 III 1960, k. 462-464).

102 Ibidem. 
then - after agreeing to a cooperation under the pseudonym "Irena" - wrote, dictated by the officers, a statement from which it was revealed that she was responsible for the arrest of the courier. This was to protect the most valuable agent used in the present case from suspicions of $\mathrm{ZCz}$ OUN. After a short stay in Zielona Góra, the resident of Gorzów was allowed to return to her home, where she was monitored by workers from central and provincial counterintelligence units, who were to prevent her from making uncontrolled contacts with third parties ${ }^{103}$. In the subsequent stages of operation "Stonka", the detained and "reversed" by the SB Bandera's couriers (apart from Haniak, Michał Dawydiak "Bystryj" and Piotr Lewicki "Czornota") participated in activities paralyzing ZCz OUN activities against the Eastern Bloc countries. It was not until February 1961 that Haniak and Lewicki made a fictitious disclosure to the Polish authorities on the orders of the "security". Their statements prepared by SB were publicized in the mass media ${ }^{104}$.

In August 1964, due to the alleged arriving of nationalist emissaries from the

103 Ibidem, Dalszy ciąg szczegółowego streszczenia uzyskanych materiałów w sprawie agenturalnego rozpracowania krypt. "Stonka" według stanu na dzień 29 II 1960 r., 31 III 1960, c. 437-439.

104 Kwestia ukraińska $w$ działalności Służby Bezpieczeństwa PRL. Dokumenty i materiał, wstęp i oprac. A. Słabig, Warszawa 2016, doc. No. 32, Telefonogram zastępcy naczelnika Wydziału V Departamentu II MSW do naczelników wydziałów II komend wojewódzkich MO w sprawie badania reakcji środowiska ukraińskiego na ujawnienie się kurierów banderowskich, 3 II 1961, p. 224.
Bandery do komendantów „podziemia” na Ukrainie, instrukcje dotyczące szyfrowania listów, wykaz zadań do wykonania w USRR, opis map, fotografia służącą jako znak rozpoznawczy przy nawiązaniu kontaktu z członkami siatki w USRR). „Worona” niezwłocznie przewieziono do Warszawy do dyspozycji Naczelnej Prokuratury Wojskowej, która zadecydowała o osadzeniu aresztanta w więzieniu na Mokotowie. Zatrzymana Jaworska przekazała SB wszystkie rzeczy pozostawione przez Haniaka w jej mieszkaniu, a następnie - po wyrażeniu zgody na współpracę pod pseudonimem „Irena” - napisała pod dyktando funkcjonariuszy oświadczenie, z którego wynikało, że spada na nią odpowiedzialność za aresztowania kuriera. Miało to uchronić najcenniejszą agenturę wykorzystaną w niniejszej sprawie przed podejrzeniami ze strony ZCz OUN. Po krótkim pobycie w Zielonej Górze pozwolono mieszkance Gorzowa powrócić do domu, gdzie znajdowała się pod obserwacją pracowników z centralnych i wojewódzkich ogniw kontrwywiadu, którzy mieli jej uniemożliwić nawiązanie niekontrolowanych kontaktów z osobami trzeci$\mathrm{mi}^{103}$. W kolejnych etapach operacji „Stonka” zatrzymani i „odwróceni” przez SB kurierzy banderowscy (prócz wspomnianego Haniaka, Michał Dawydiak „Bystryj” i Piotr Lewicki „Czornota”) wzięli udział w działaniach paraliżujących aktywność ZCz OUN wobec państw bloku wschodniego. Dopiero w lutym 1961 r. na pole-

103 Ibidem, Dalszy ciąg szczegółowego streszczenia uzyskanych materiałów w sprawie agenturalnego rozpracowania krypt. „Stonka” według stanu na dzień 29 II 1960 r., 31 III 1960, k. 437-439. 
West in Wrocław, counterintelligence workers in Zielona Góra were instructed to intensify their operational work in the Ukrainian environment. Particular supervision was recommended to a group of people (including six from the Nowa Sól county) who had contacted in the past with couriers, visited by Ukrainian expatriates, having friends or families in the OUN and keeping correspondence contacts with them ${ }^{105}$. A plan for the protection of the area of the province was also prepared, in which one declared the need to intensify the control over former UPA members and "den owners" (formerly providing shelter to couriers), provide current inflows of information from hotels and other lodgings, and control "nationalist elements" escaping agent observation. The most valuable agents were put on standby (SCs: "Roman", "Irek", "Krakus", "X-60", "Wiśniewski”, "Bohun", "Jawor", "Szewczuk" and "Bogus'"). They were ordered to observe people who could potentially support visitors from the West. Border Control Offices and the Independent Section of Foreigners' Movement were expected to notify immediately the counterintelligence in Zielona Góra of all cases of bor-

105 AIPN Po, 0038/27, vol. 3, Pismo dyrektora Departamentu II MSW do zastępcy komendanta wojewódzkiego MO ds. Bezpieczeństwa w Zielonej Górze, 21 VIII 1964, c. 239; ibidem, Pismo dyrektora Departamentu II MSW do naczelnika Wydziału II KW MO w Zielonej Górze, 14 IX 1964, c. 241; ibidem, Depesza szyfrowa wychodząca naczelników Wydziałów II i III do zastępców komendantów powiatowych MO ds. bezpieczeństwa, 23 XI 1964, c. 242 cenie „bezpieki” Haniak i Lewicki dokonali fikcyjnego ujawnienia przed polskimi władzami. Ich spreparowane przez SB oświadczenia zostały nagłośnione w środkach masowego przekazu ${ }^{104}$.

W sierpniu 1964 r., w związku z rzekomym pojawieniem się w województwie wrocławskim nacjonalistycznych emisariuszy z Zachodu, polecono pracownikom kontrwywiadu w Zielonej Górze zintensyfikować pracę operacyjną $\mathrm{w}$ środowisku ukraińskim. Szczególnym nadzorem zalecano objąć grupę osób (w tym sześć z powiatu nowosolskiego) kontaktujących się w przeszłości z kurierami, odwiedzanych przez emigrantów ukraińskich, posiadających znajomych lub rodziny w OUN i utrzymujących z nimi kontakty korespondencyjne ${ }^{105}$. Opracowano także plan zabezpieczenia terenu województwa, w którym deklarowano konieczność wzmożenia kontroli b. upowców i „meliniarzy" (czyli osób niegdyś udzielających schronienia kurierom), zapewniania bieżącego dopływu informacji z hoteli i innych miejsc noclegowych oraz kontro-

104 Kwestia ukraińska w działalności Stużby Bezpieczeństwa PRL. Dokumenty i materiat, wstęp i oprac. A. Słabig, Warszawa 2016, dok. nr 32, Telefonogram zastępcy naczelnika Wydziału V Departamentu II MSW do naczelników wydziałów II komend wojewódzkich MO w sprawie badania reakcji środowiska ukraińskiego na ujawnienie się kurierów banderowskich, 3 II 1961, s. 224.

105 AIPN Po, 0038/27, t. 3, Pismo dyrektora Departamentu II MSW do zastępcy komendanta wojewódzkiego MO ds. Bezpieczeństwa w Zielonej Górze, 21 VIII 1964, k. 239; ibidem, Pismo dyrektora Departamentu II MSW do naczelnika Wydziału II KW MO w Zielonej Górze, 14 IX 1964, k. 241; ibidem, Depesza szyfrowa wychodzaca naczelników Wydziałów II i III do zastępców komendantów powiatowych MO ds. bezpieczeństwa, $23 \mathrm{XI}$ 1964, k. 242. 
der crossing or registration of the stay by foreigners of Ukrainian nationality ${ }^{106}$.

After a temporary reduction in the state of personal information sources, the reorganized security apparatus in mid-1957 proceeded to the intensive rebuilding of the network of agents in the Ukrainian environment. In January 1960, it counted a total of 10 informants ${ }^{107}-2$ of them cooperated with Group III of the Division III of KW MO in Zielona Góra, and $8^{108}$ with SB county units. In June 1961, a total of 25 SCs were reported, 7 of them in contact of Group III of the Division III and 18 in SB county units. Lastly, in November 1966, the Ukrainian environment was being dealt with by 15 SCs, out of which 13 in SB county units ${ }^{109}$. We have less data on the number of the Ukrainian agents of Group V of the Division II. In 1962, it had 5 co-workers, and a year later, 3 , and 4 operational contacts and 1 contact office ${ }^{110}$.

106 Ibidem, Plan operacyjnego zabezpieczenia terenu województwa zielonogórskiego, 1 IX 1964, c. 248-249.

107 Their pseudonyms were: "Roman", "Homo", "Gajewski”, "Prawdziwy”, "Janek”, "Setnik”, "Romańczuk", “Jaskółka”, "Bohun” and "Janusz".

108 AINR Po, 0038/27, vol. 1, Kontrwywiadowcza charakterystyka zagadnienia nacjonalizmu ukraińskiego na terenie województwa zielonogórskiego, 13 I 1960, c. 50.

109 AINR Po, 0038/27, vol. 3, Informacja na temat sytuacji operacyjnej po zagadnieniu nacjonalizmu ukraińskiego, 22 XI 1966, c. 342.

110 We know pseudonyms of four Ukrainian informants of the counterintelligence in Zielona Góra: "Heniek", "Szewczuk", "Jan” and "Zbyszek" (AINR Po, 0038/27, vol. 2, Analiza pracy operacyjnej Grupy V Wydziału II KW MO w Zielonej Górze po zagadnieniu nacjonalizmu ukraińskiego za rok 1962, 19 XII li „elementów nacjonalistycznych” wymykających się obserwacji agenturalnej. W stan gotowości postawiono najcenniejszą agenturę (tajni współpracownicy: „Roman”, „Irek”, „Krakus”, „X-60”, „Wiśniewski”, „Bohun”, „Jawor”, „Szewczuk” i „Bogus'”), której polecono obserwować osoby mogące stanowić potencjalne oparcie dla przybyszy z Zachodu. Graniczne Placówki Kontroli i Samodzielna Sekcja Ruchu Cudzoziemców miały niezwłocznie powiadamiać zielonogórski kontrwywiad o wszystkich przypadkach przekraczania granicy czy też rejestrowania pobytu przez cudzoziemców narodowości ukraińskiej ${ }^{106}$.

Po przejściowej redukcji stanu osobowych źródeł informacji zreorganizowany aparat bezpieczeństwa w połowie $1957 \mathrm{r}$. przystąpił do intensywnej odbudowy sieci agenturalnej w środowisku ukraińskim. W styczniu $1960 \mathrm{r}$. liczyła ona łącznie 10 informatoró $w^{107}$ - z Grupą III Wydziału III KW MO w Zielonej Górze współpracowało 2, a z powiatowymi referatami SB $8^{108}$. W czerwcu $1961 \mathrm{r}$. wykazano łącznie 25 TW, z tego 7 na kontakcie Grupy III Wydziału III, a $18 \mathrm{w}$ powiatowych referatach SB. Wreszcie w listopadzie 1966 r. środowisko ukraińskie rozpracowywało $15 \mathrm{TW}$, $\mathrm{z}$ tego $13 \mathrm{w}$ powiatowych referatach $\mathrm{SB}^{109}$.

106 Ibidem, Plan operacyjnego zabezpieczenia terenu województwa zielonogórskiego, 1 IX 1964, k. 248-249.

107 Informatorzy ci nosili pseudonimy: „Roman”, „Homo”, „Gajewski”, „Prawdziwy”, „Janek”, „Setnik”, „Romańczuk”, „Jaskółka”, „Bohun” i „Janusz".

108 AIPN Po, 0038/27, t. 1, Kontrwywiadowcza charakterystyka zagadnienia nacjonalizmu ukraińskiego na terenie województwa zielonogórskiego, 13 I 1960, k. 50.

109 AIPN Po, 0038/27, t. 3, Informacja na temat sytuacji operacyjnej po zagadnieniu nacjonalizmu ukraińskiego, 22 XI 1966, k. 342. 
The most valuable confidents were obtained among those who belonged to anti-communist armed and political organizations, especially those who had been broken up by many years in prisons and labor camps. In the documents, they performed under the pseudonyms: "Roman"111, "Wiśniewski"112, "Krakus"113,

1962, c. 450-455; ibidem, Analiza pracy operacyjnej za okres 1 I-31 XII 1963, c. 201-202).

111 It was Grzegorz Kisilewski "Czaban" - Bandera's courier, sent with a mission to the country in 1950. After his detention in 1951, he was handed over to the Soviet authorities, which sentenced him to 25 years imprisonment. After his release, he came to Poland in 1955. Two years later, SB in Zielona Góra acquired him "on a loyalty basis". He provided general information materials on UTSK regional activists and subsequent expeditions of Bandera's emissaries. It was planned to use him to penetrate the political structures of the Ukrainian emigrants and underground veterans. He provided only verbal information, he was paid several times in cash (AINR Po, 0038/27, vol. 1, Raport z podróży służbowej do Wydziału III KW MO w Zielonej Górze w dniach 13-17 IV 1959, c. 196).

112 Obtained in September 1957 "on loyalty basis", former member of the Ukrainian underground. He had been staying in the Soviet army, "good conspirator, but insincere". He belonged to the UTSK in Zielona Góra (ibidem, Analiza kontrwywiadowcza terenu województwa zielonogórskiego po zagadnieniu nacjonalizmu ukraińskiego, 18 VIII 1958, c. 20).

113 "Krakus" was recruited by prison institutions in Nowogard in 1954, where he was sentenced to 12 years imprisonment for belonging to the Sluzhba Bezpeky OUN in Przemyśl County (ibidem, Sprawozdanie Grupy III Wydziału III po zagadnieniu nacjonalizmu ukraińskiego i białoruskiego za II kwartał 1960 r., 28 VI 1960, c. 467).
Mniej danych posiadamy na temat liczebności ukraińskiej agentury Grupy V Wydziału II. W 1962 r. dysponowała 5 tajnymi współpracownikami, a rok później 3, oraz 4 kontaktami operacyjnymi i 1 lokalem kontaktowym ${ }^{110}$.

Najcenniejszych konfidentów pozyskano wśród osób obciążonych przynależnością do antykomunistycznych organizacji zbrojnych i politycznych, zwłaszcza tych złamanych wieloletnim pobytem $\mathrm{w}$ więzieniach i obozach pracy. W dokumentach występowali pod pseudonimami: „Roman”111, „Wiśniewski”"112,

110 Znane sa pseudonimy czterech ukraińskich informatorów zielonogórskiego kontrwywiadu: „Heniek”, „Szewczuk”, „Jan” i „Zbyszek” (AIPN Po, 0038/27, t. 2, Analiza pracy operacyjnej Grupy V Wydziału II KW MO w Zielonej Górze po zagadnieniu nacjonalizmu ukraińskiego za rok 1962, 19 XII 1962, k. 450-455; ibidem, Analiza pracy operacyjnej za okres 1 I-31 XII 1963, k. 201-202).

111 Był to Grzegorz Kisilewski „Czaban” - kurier banderowski wysłany w $1950 \mathrm{r}$. z misją do kraju. Po zatrzymaniu w 1951 r., przekazany władzom radzieckim, które skazały go na 25 lat pozbawienia wolności. Po zwolnieniu przyjechał do Polski w 1955 r. Dwa lata później zielonogórska SB pozyskała go „na zasadzie lojalności”. Przekazywał materiały ogólnoinformacyjne dotyczące wojewódzkich aktywistów UTSK i kolejnych wypraw emisariuszy banderowskich. Planowano użyć go do penetracji politycznych struktur emigracji ukraińskiej i weteranów podziemia. Przekazywał wyłącznie ustne informacje, kilkakrotnie był wynagradzany pieniężnie (AIPN Po, 0038/27, t. 1, Raport z podróży służbowej do Wydziału III KW MO w Zielonej Górze w dniach 13-17 IV 1959, k. 196).

112 Pozyskany we wrześniu 1957 r. „,na zasadzie lojalności”, b. członek ukraińskiego podziemia. Miał za sobą pobyt $w$ radzieckich łagrach, ,dobry konspirator, lecz nieszczery". Należał do ZW UTSK w Zie- 
"Jan"114, "Gerwazy"115 and "Setnik"116.

114 The confident was Teodor Dak. He belonged to the Melnyk's faction of the OUN, SS "Galizien" soldier. In 1945, he got to a POW camp in Italy, from where he went to Munich. Two years later, he was transferred to Poland with the task of conducting intelligence activities, which he eventually did not undertake. Until 1952, he was hiding under a false name. Arrested and sentenced to 15 years' imprisonment, he was released under amnesty in 1956 . He lived in the territory of the Nowa Sól county, where he was recruited "on loyalty basis" in September 1959. He was to be involved in surveillance of the old and current sympathizers of the Melnyk's movement in Poland and Canada, which the SB and the KGB were interested in. Privately they were his former friends or relatives (AINR Po, 0038/27, vol. 5, Plan sprawdzenia i wykorzystania informatora ps. “Jan”, 28 X 1959, c. 43-45).

115 It was Stefan Semeniuk vel Stefan Dranicki, cadre activist of the political unit and secretary of the OUN in Volyn. Until 1955, hiding his past, he stayed as a serial soldier of UPA in the Soviet labor camp. After arriving in Poland, he settled in Gorzów Wielkopolski. Under the case codename "Wschód" he was heavily controlled by the agents and the SB officers. In October 1962, he agreed to cooperate as an SC. At first, he was controlling the local Ukrainian environment and later he took part in operating games against emigrant community (AINR Po, $0038 / 27$, vol. 3, Uwagi do doniesienia TW ps. "Gerwazy”, 15 IX 1964, c. 255; ibidem, Raport z kontroli Grupy III Wydziału III KW MO w Zielonej Górze przeprowadzony przez pracowników Wydziału III Departamentu III MSW w dniach 7-11 V 1963 po zagadnieniu nacjonalizmu ukraińskiego i białoruskiego, 10 V 1963, c. 76-77; ibidem, Notatka służbowa z odbytego spotkania w dniu 8 VII 1963, c. 114-115).

116 He was from Przemyśl country. During the war, he first went to the Shutzmannschaftbatallion in the labor camp in Pustków near Dębica and then probably to the SS "Galizien". He was captured by the Soviets after the Battle of Brody. After the war, he settled in Torzym in Sulęcin County. In spite of the burdensome past, thanks to the cooperation with the security apparatus, he was allowed to work in the local administration and agricultural circles. he was the main source of information on the record and observation case codename "Florynka" (AINR Po, 0038/27, vol. 12, Pismo zastepcy komendanta powiatowego MO ds. bezpieczeństwa w Sulęcinie do naczelnika Wydziału III KW MO w Zielonej Górze,
„Krakus”113, „Jan”114. „Gerwazy”115 i „Setnik"116. Ze względu na swoją bogatą prze-

lonej Górze (ibidem, Analiza kontrwywiadowcza terenu województwa zielonogórskiego po zagadnieniu nacjonalizmu ukraińskiego, 18 VIII 1958, k. 20).

113 „Krakus” był zwerbowany przez organa więzienne w Nowogardzie w 1954 r., gdzie odbywał kare 12 lat pozbawienia wolności za przynależność do Służby Bezpeky OUN w powiecie przemyskim (ibidem, Sprawozdanie Grupy III Wydziału III po zagadnieniu nacjonalizmu ukraińskiego i białoruskiego za II kwartał 1960 r., 28 VI 1960, k. 467).

114 Wskazanym konfidentem był Teodor Dak. Należał do melnykowskiego odłamu OUN, żołnierz SS „Galizien”. W 1945 r. znalazł się w obozie jenieckim we Włoszech, skąd przedostał się do Monachium. Dwa lata później przerzucono go do Polski z zadaniem prowadzenia działalności wywiadowczej, której ostatecznie nie podjął. Do 1952 r. ukrywał się pod fałszywym nazwiskiem. Aresztowany i skazany na 15 lat pozbawienia wolności, wyszedł na wolność na mocy amnestii w 1956 r. Zamieszkał na terenie powiatu nowosolskiego, gdzie zwerbowano go „na zasadzie lojalności” we wrześniu 1959 r. Miał być zaangażowany w rozpracowanie dawnych i aktualnych sympatyków ruchu melnykowskiego w Polsce i Kanadzie, pozostających w zainteresowaniu SB i KGB. Prywatnie byli to jego dawni znajomi lub powinowaci (AIPN Po, 0038/27, t. 5, Plan sprawdzenia i wykorzystania informatora ps. „Jan", 28 X 1959, k. 43-45).

115 Był to Stefan Semeniuk vel Stefan Dranicki, kadrowy działacz referentury politycznej i sekretarz OUN na Wołyniu. Do 1955 r., zatajając swoją przeszłość, przebywał jako szeregowy żołnierz UPA w radzieckim obozie pracy. Po przyjeździe do Polski osiadł w Gorzowie Wielkopolskim. W ramach sprawy kryptonim „Wschód” był intensywnie kontrolowany przez agenturę i funkcjonariuszy SB. W październiku 1962 r. zgodził się na współpracę w charakterze TW. Początkowo kontrolował lokalne środowisko ukraińskie, a później wziął udział w grach operacyjnych wobec środowisk emigracyjnych (AIPN Po, 0038/27, t. 3, Uwagi do doniesienia TW ps. „Gerwazy”, 15 IX 1964, k. 255; ibidem, Raport z kontroli Grupy III Wydziału III KW MO w Zielonej Górze przeprowadzony przez pracowników Wydziału III Departamentu III MSW w dniach 7-11 V 1963 po zagadnieniu nacjonalizmu ukraińskiego i białoruskiego, 10 V 1963, k. 76-77; ibidem, Notatka służbowa $\mathrm{z}$ odbytego spotkania w dniu 8 VII 1963, k. 114-115).

116 Pochodził z powiatu przemyskiego. W czasie wojny wstąpił najpierw do Shutzmannschaftbatal- 
Owing to their rich past, numerous social contacts and the trust they enjoyed in the Ukrainian and foreign communities they were potentially dangerous tools in the operation activities. Over time, efforts were made to gain the "unexplained" wars of the representatives of the Ukrainian intelligentsia - clerics, UTSK activists and students. Among others secret associates with the nicknames "Dzik", "Homo", "X-60", "Czapka" and "Irek" belonged to this group. During their recruitment, they were reminded of their loyalty to the socialist fatherland and the need to participate in the fight against the omnipresent evil embodied by "nationalists" in the country and in the West. If necessary, these arguments were skillfully combined with material incentives (in one case, it was a voucher for a motorbike worth 2 thousand zlotys) and help to solve a wide range of social and living problems (e.g. by canceling overdue payments to the state). If these arguments failed they resorted to blackmail.

In the 1970s, the local authorities of the Security Service, primarily the province and county ones, were involved in the surveillance of the Ukrainian minority in Ziemia Lubuska, and after 1975, or after the liquidation of counties almost exclusively the province SB authorities of Zielona Góra and Gorzów Wielkopolski. Occasionally, due to the importance of a single operational matter, officers of the central units of Ministry of Interior and Soviet

16 XII 1959, c. 58-59; ibidem, Charakterystyka informatora ps. "Setnik", 4 XI 1958, c. 39; ibidem, Charakterystyka TW ps. „Setnik”, 20 IV 1965, c. 104). szłość, liczne kontakty towarzyskie oraz zaufanie, jakim cieszyli się w środowiskach ukraińskich w kraju i za granicą, stanowili potencjalnie groźne narzędzie w działaniach operacyjnych. Z czasem starano się pozyskać do współpracy „nieskompromitowanych" zaszłościami wojennymi przedstawicieli inteligencji ukraińskiej - duchownych, działaczy UTSK i studentów. Do tego grona należeli m.in. tajni współpracownicy o pseudonimach „Dzik”, „Homo”, „X-60”, „Czapka” i „Irek”. $\mathrm{W}$ trakcie ich werbunku przypominano o obowiązującej lojalności wobec socjalistycznej ojczyzny i potrzebie uczestniczenia w walce $\mathrm{z}$ wszechobecnym złem uosabianym przez "nacjonalistów” w kraju i na Zachodzie. W razie potrzeby argumenty te umiejętnie łączono $\mathrm{z}$ bodźcami materialnymi ( $\mathrm{w}$ jednym przypadku był to talon na motocykl wartości 2 tys. zf) i pomocą $\mathrm{w}$ rozwiązaniu rozmaitych problemów socjalno-bytowych (m.in. poprzez anulowanie zaległych opłat na rzecz państwa). Jeśli te argumenty zawodziły, uciekano się do szantażu.

W latach 70. w rozpracowanie mniejszości ukraińskiej na Ziemi Lubuskiej zaangażowane były przede wszystkim lokal-

lion w obozie pracy w Pustkowie k. Dębicy, a potem prawdopodobniej do SS „Galizien”. Trafił do niewoli radzieckiej po bitwie pod Brodami. Po wojnie zamieszkał w Torzymiu w powiecie sulęcińskim. Mimo obciążającej przeszłości, dzięki współpracy z aparatem bezpieczeństwa przyzwolono mu na pracę w lokalnej administracji i kółkach rolniczych. Był głównym źródłem informacji w sprawie ewidencyjno-obserwacyjnej krypt. „Florynka” (AIPN Po, 0038/27, t. 12, Pismo zastępcy komendanta powiatowego MO ds. bezpieczeństwa w Sulęcinie do naczelnika Wydziału III KW MO w Zielonej Górze, 16 XII 1959, k. 58-59; ibidem, Charakterystyka informatora ps. „Setnik”, 4 XI 1958, k. 39; ibidem, Charakterystyka TW ps. „Setnik”, 20 IV 1965, k. 104). 
special forces, mainly related to military counterintelligence under the command of the North Soviet Group. In the organizational structure of the security apparatus at the provincial level primarily the Division III (established to combat opposition activity) of the Provincial Civic Militia Headquarters (KW MO), and at the district level the Security Service units (RdsSB) in the County MO (KP MO) were responsible for surveillance of the Ukrainian minority. Their tasks included both the comprehensive control of the Ukrainian population and the special surveillance of the UTSK under the pretext of "protecting the association from hostile nationalist activity". To a lesser degree, confined exclusively to religious matters, the Division IV of KW MO and the department dealing with passports and registration of foreigners were involved. The latter was used to conduct preliminary identification of persons seeking to leave or visiting Ukrainians-foreigners. The cooperation between the operational units (i.e. $\mathrm{SB})$ of the Ministry of Interior and its social-administrative units played a significant role in (dual as it appears) supervising the Ukrainian minority.

With the aim of strengthening the social discipline among people of Ukrainian and Jewish nationalities and preventing the creation of conditions for illegal activity from the legal position - to expand the contacts and cooperation with the Interior Departments of the $\mathrm{Mu}$ nicipal and District Presidiums of the Municipal and County National Councils, ne struktury Służby Bezpieczeństwa - początkowo wojewódzkie i powiatowe, a po 1975 r., czyli po zlikwidowaniu powiatów, niemal wyłącznie wojewódzkie w Zielonej Górze i Gorzowie Wielkopolskim. Sporadycznie, ze względu na wagę pojedynczej sprawy operacyjnej, włączali się do nich funkcjonariusze centralnych pionów MSW oraz pracownicy radzieckich służb specjalnych, związani przede wszystkim z kontrwywiadem wojskowym podlegającym dowództwu Północnej Grupy Wojsk Radzieckich. W strukturze organizacyjnej aparatu bezpieczeństwa za inwigilację mniejszości ukraińskiej na szczeblu wojewódzkim był odpowiedzialny przede wszystkim Wydział III (powołany do zwalczania działalności opozycyjnej) Komendy Wojewódzkiej Milicji Obywatelskiej (KW MO), a na poziomie powiatów Referaty do spraw Służby Bezpieczeństwa (RdsSB) w Komendach Powiatowych MO (KP MO). Do ich zadań należała zarówno kompleksowa kontrola ludności ukraińskiej, jak i roztoczenie szczególnego nadzoru nad UTSK pod pretekstem „ochrony stowarzyszenia przed wrogą nacjonalistyczną działalnością". W mniejszym stopniu, ograniczonym wyłącznie do spraw wyznaniowych, angażowano Wydział IV KW MO oraz pion zajmujący się sprawami paszportowymi i rejestracją cudzoziemców. Ten ostatni wykorzystywano do prowadzenia wstępnego rozpoznania osób ubiegających się o wyjazd, względnie przyjeżdżających z wizytą Ukraińców-obcokrajowców. Duże znaczenie w sprawowaniu nadzoru (dwutorowego jak się okazuje) nad mniejszością ukraińską od- 
stated the head of the SB unit from Zielona Góra ${ }^{117}$. The social and administrative structures on Ziemia Lubuska until 1975 were organized within the Office of Internal Affairs (USW) at the PWRN in Zielona Gorra and the Interior Departments (WSW) at the county national councils mentioned in the documents. After the territorial division reform, these were the departments of interior affairs at the Provincial Administration Offices in Gorzów Wielkopolski and Zielona Góra. Representatives of the administration, holding the official guardianship of the UTSK, conveyed a plenty of information about the association to the security services, performed tasks assigned by the SB (e.g. warnings, participation in provocations) and participated in the electing of the politically proper activists of the organization ${ }^{118}$.

In the seventies of the last century, the operational work of SB on the Ukrainian minority in Ziemia Lubuska took on a prophylactic character, supporting broader efforts to denationalize the environment. The documents in the SB unit in Międzyrzecz explicitly stated that the work initiated in November 1970 aimed to "identify and counteract all attempts and manifestations that undermine the assim-

117 AINR Po, 060/97, vol. 8, Plan pracy SB KMiP MO na 1970 r., 5 I 1970, c. 122v.

118 J. Syrnyk, Ukraińskie Towarzystwo..., p. 199. According to the author, "In the 1970s the depreciation of the meaning and role of administrative structures appeared [...] which could be described as their deeper vassalisation towards the security unit" (ibidem, p. 175). grywała współpraca między pionami operacyjnymi (czyli SB) MSW a jego pionem społeczno-administracyjnym.

Mając na uwadze wzmocnienie dyscypliny społecznej w środowiskach osób narodowości ukraińskiej i żydowskiej oraz zapobieganie powstawaniu warunków do prowadzenia szkodliwej działalności z pozycji legalnej - rozszerzyć kontakty służbowe i współdziałanie z Wydziałami Spraw Wewnętrznych Prezydiów Miejskiej i Powiatowej Rady Narodowej

- stwierdziło kierownictwo referatu SB z Zielonej Góry ${ }^{117}$. Struktury społeczno-administracyjne na Ziemi Lubuskiej do 1975 r. zorganizowano w ramach Urzędu Spraw Wewnętrznych (USW) przy PWRN w Zielonej Górze i wydziałów spraw wewnętrznych (WSW) przy wymienionych $\mathrm{w}$ dokumencie prezydiach powiatowych rad narodowych. Po reformie podziału terytorialnego były to wydziały spraw wewnętrznych przy Urzędach Wojewódzkich w Gorzowie Wielkopolskim i Zielonej Górze. Przedstawiciele administracji, sprawując urzędową kuratelę nad UTSK, przekazywali bezpiece wiele informacji o stowarzyszeniu, wykonywali zlecone przez SB zadania (np. rozmowy ostrzegawcze, udział w prowokacjach) oraz współuczestniczyli w wyłanianiu właściwego, pod względem politycznym, aktywu organizacji ${ }^{118}$.

W latach 70. ubiegłego wieku praca operacyjna SB wobec mniejszości ukraiń-

117 AIPN Po, 060/97, t. 8, Plan pracy SB KMiP MO na 1970 r., 5 I 1970, k. 122v.

118 J. Syrnyk, Ukraińskie Towarzystwo..., s. 199. Zdaniem tego autora, „W latach siedemdziesiątych uwidoczniła się deprecjacja znaczenia i roli struktur administracyjnych [...], które można byłoby określić mianem głębszej ich wasalizacji wobec pionu bezpieczeństwa" (ibidem, s. 175). 
ilation process"119. Compared to the previous decade, the scale of repression had decreased. By the end of the sixties under the guise of fighting "Ukrainian nationalism", those social activists, who tried to make UTSK a real representative of Ukrainians in Poland, were effectively suppressed, restricted and their contacts with Ukrainian immigrant organizations were controlled. The last hiding people who had fought in the underground, or at the side of the German occupant, were arrested and brought to court ${ }^{120}$. The Ukrainian environment became extremely cautious and distrustful of outsiders. They avoided causing irritations that could prompt authorities to exacerbate repression. On the other hand, they were aware of the far-reaching consequences of forced relocation. The pace of assimilation of people of Ukrainian origin, especially those whose national identity was not adequately grounded, but also those living in the vicinity of the Polish population, was gaining momentum. Hence the area of interest of the SB narrowed. At the time, they primarily focused on people who clearly emphasized their ethnic distinctiveness, who were involved in the life of the UTSK and local Greek Catholic communities. Only for some figurants (i.e. invigilated persons) you could point to additional aggravating factors: unofficial criticism of the political system, problem-

119 AINR Sz, 004/31, Wniosek o wszczęcie sprawy obiektowej kryptonim "Beta-3", 13 XI 1970, c. 5.

120 See: J. Syrnyk, Ukrainskie Towarzystwo..., pp. 202, 218-219. skiej na Ziemi Lubuskiej przybierała charakter profilaktyczny, wspomagający szersze działania na rzecz wynarodowienia tego środowiska. W dokumentach referatu SB w Międzyrzeczu jednoznacznie stwierdzono, że zainicjowane w listopadzie 1970 r. rozpracowanie ma zmierzać do „rozpoznania i przeciwdziałania wszelkim próbom i przejawom osłabiającym proces asymilacji”"119. W porównaniu z poprzednią dekadą spadła skala represji. Do końca lat 60 . pod pozorem walki $\mathrm{z}$,nacjonalizmem ukraińskim" skutecznie zastraszono aktywistów społecznych, którzy usiłowali uczynić z UTSK rzeczywistego reprezentanta Ukraińców w Polsce, ograniczono i poddano kontroli kontakty z ukraińskimi organizacjami emigracyjnymi oraz wyłapano i postawiono przed sądem ostatnie ukrywające się osoby walczące w przeszłości w podziemiu, względnie u boku niemieckiego okupanta ${ }^{120}$. Środowisko ukraińskie stało się niezwykle ostrożne i nieufne wobec ludzi z zewnątrz. Unikało wywoływania zadrażnień, które mogłyby skłonić władze do zaostrzenia represji. $\mathrm{Z}$ drugiej strony dawały znać o sobie dalekosiężne skutki przymusowego przesiedlenia. Nabierała tempa asymilacja osób pochodzenia ukraińskiego, zwłaszcza tych, których tożsamość narodowa nie była dostatecznie ugruntowana, a przy tym żyjących w otoczeniu ludności polskiej. Tym samym kurczyło się pole zainteresowania $\mathrm{SB}$, które w tym czasie obejmowało przede wszystkim osoby jednoznacznie podkre-

119 AIPN Sz, 004/31, Wniosek o wszczęcie sprawy obiektowej kryptonim „Beta-3”, 13 XI 1970, k. 5.

120 Por. J. Syrnyk, Ukraińskie Towarzystwo..., s. $202,218-219$. 
atic (but mostly settled) past, contacts with "nationalists" in the West, and violations of applicable law. It can be assumed that the omission during this period of drastic repression against the Ukrainian minority was, to some extent, an expression of SB's general tactic of "harassing an opponent without attempting a major fight". Concerned about the negative reaction of Western states and the possible consolidation of opposition circles in the People's Republic of Poland, they abandoned the "hard course" in favor of the expansion of the agent network, disintegration and compromising the opponent ${ }^{121}$.

As already mentioned in the introduction, the surveillance of the Ukrainian environment on Ziemia Lubuska in the 1970s was carried out in the field of the object case codename "Beta". Until 1975 local variants of this surveillance (so-called cuttings) were numbered depending on the location of the county in the province. For example, in the SB unit in the Municipal and County Headquarters (KMiP) MO in Gorzów Wielkopolski, it functioned as "Beta-1" and in its equivalent in Zielona Góra as "Beta-7". Since 1970, object cases were designed to ensure a continuous flow of information on the environments that were identified as being at risk for var-

121 The proponent of the "soft attitude" was, among others. Adam Krzysztoporski, then director of the Department III of the Ministry of Interior, responsible for both the Polish opposition and the national minorities (R. Terlecki, Miecz i tarcza komunizmu. Historia aparatu bezpieczeństwa w Polsce 1944-1990, Kraków 2008, pp. 237-238). ślające swoją odrębność etniczną, udzielające się przy tym w życiu UTSK i lokalnych wspólnot greckokatolickich. Tylko w przypadku niektórych figurantów (czyli inwigilowanych osób) można było wskazać na dodatkowe czynniki obciążające: nieoficjalną krytykę systemu politycznego, problematyczną (ale najczęściej rozliczoną) przeszłość, kontakty z „nacjonalistami” na Zachodzie oraz łamanie obowiązującego prawa. Można przypuszczać, że zaniechanie $\mathrm{w}$ tym okresie drastycznych represji wobec mniejszości ukraińskiej było też w jakiejś mierze wyrazem przyjętej przez SB ogólnej taktyki „nękania przeciwnika bez próby walnej rozprawy". W obawie przed negatywną reakcją państw zachodnich i ewentualną konsolidacją środowisk opozycyjnych w PRL, zrezygnowano $\mathrm{z}$,twardego kursu” na rzecz rozbudowy sieci agenturalnej, dezintegracji i kompromitacji przeciwnika ${ }^{121}$.

Jak już wspomniano we wstępie, rozpracowanie środowiska ukraińskiego na Ziemi Lubuskiej w latach 70. prowadzono w ramach sprawy obiektowej kryptonim „Beta”. Do 1975 r. lokalne warianty tego rozpracowania (tzw. wycinki) numerowano w zależności od położenia powiatu w województwie. Na przykład w referacie SB w Komendzie Miejskiej i Powiatowej (KMiP) MO w Gorzowie Wielkopolskim funkcjonowało ono jako „Beta-1", a w jego odpowiedniku w Zielonej Górze jako „Beta-7”.

121 Zwolennikiem „miękkiego kursu” był m.in. Adam Krzysztoporski, ówczesny dyrektor Departamentu III MSW, struktury odpowiadającej zarówno za działania wobec polskiej opozycji, jak i mniejszości narodowych (R. Terlecki, Miecz i tarcza komunizmu. Historia aparatu bezpieczeństwa w Polsce 19441990, Kraków 2008, s. 237-238). 
ious "dangers". The "object cases" consisted of relatively numerous single cases of so-called registration questionnaires (KE) to monitor the lives of persons considered potentially threatening to the system. The operational checking cases (SOS) were initiated less frequently, after acquiring the initial, unconfirmed information about the preparation or conduct of antisystem activity. As soon as it was confirmed, a case of operational surveillance (SOR) was instituted, of which aim was documenting activities contrary to the then law ${ }^{122}$.

The agent network used in the "Beta" case was made up of secret collaborator (SC), operational contacts (OC) and business contacts (BC). Briefly, the first category included people purposely recruited by the SB to identify, detect or prevent "hostile activity". On the other hand, operational contacts (often PZPR members) provided, as often as possible, on their own initiative, general information on the problem in question. They were excluded from the written acceptance of the cooperation. Lastly, staff contacts were held with managers (e.g. representatives of the administration) who, due to their nature of work and knowledge of specific issues, were obliged to inform the SB about the matters of interest ${ }^{123}$.

One of the first undertakings to open across the country a new phase of surveillance of Ukrainians was the conduct

122 F. Musiał, Podręcznik bezpieki..., pp. 242, 244-245, 249-259.

123 Ibidem, p. 348.
Od 1970 r. sprawy obiektowe były zakładane z myślą o zapewnieniu stałego dopływu informacji o środowiskach, które uznano za narażone na różnego rodzaju „niebezpieczeństwa”. W skład „obiektówek” wchodziły stosunkowo liczne pojedyncze sprawy tzw. kwestionariusze ewidencyjne (KE) służące monitorowaniu życia osób uznawanych za potencjalnie groźne dla systemu. Nieco rzadziej wszczynano sprawy operacyjnego sprawdzenia (SOS), które rozpoczynano po uzyskaniu wstępnej, niepotwierdzonej informacji o przygotowywaniu lub prowadzeniu przez kogoś działalności antysystemowej. Z chwilą, gdy ją potwierdzono, wszczynano sprawę operacyjnego rozpracowania (SOR), której celem było udokumentowanie działalności sprzecznej z ówczesnym prawem ${ }^{122}$.

Sieć agenturalna wykorzystana w sprawie „Beta” składała się z tajnych współpracowników (TW), kontaktów operacyjnych (KO) i kontaktów służbowych (KS). Najkrócej ujmując, pierwsza kategoria obejmowała osoby celowo werbowane przez SB do rozpoznania, wykrycia lub zapobieżenia „wrogiej działalności”. Z kolei kontakty operacyjne (wielokroć członkowie PZPR) udzielały w miarę możliwości, często z własnej inicjatywy, ogólnych informacji na temat danego problemu. Odstępowano w ich przypadku od pisemnej akceptacji współpracy. Wreszcie kontakty służbowe były utrzymywane $\mathrm{z}$ osobami na kierowniczych stanowiskach (m.in. przedstawicielami administracji), które ze względu na charakter pracy i znajomość określonej problematyki miały obowiązek informo-

122 F. Musiał, Podręcznik bezpieki..., s. 242, 244245, 249-259. 
of secret surveys in the fourth quarter of 1970, involving members and collaborators of the OUN and UPA, SS "Galizien" soldiers, former members of the sabotage and intelligence networks and connected with them the so called "den owners", Ukrainian police officers and people with "nationalist" views. The 32-point survey, based on archive data, was intended to give a full picture of every specific person's activity (contacts in Poland and abroad, receiving and distributing emigrant literature, listening to foreign radio stations, spreading nationalist propaganda, spreading information to emigration centers, current attitude) and the "neutralizing" actions undertaken against that person in the past (punishment, preventive and warning calls, recruitment attempts, removal from social and service posts, limitation of public speaking and publicity). Based on the results of the survey, it was decided to continue, to initiate or to stop the surveillance ${ }^{124}$. On the scale of the Zielona Gora province the materials were analyzed for 70 people, including 4 OUN members, 7 SS "Galizien" soldiers, 45 UPA members, 1 member of the so-called sabotage hit squads, 4 "den owners" (i.e. providing shelter to Ukrainian couriers) and 9 people "connected in the past with centers" ${ }^{125}$.

124 AINR Po, 024/285, Ankieta, 5 XII 1970, c. $15-20$.

125 AINR, 1509/1774, M. Śmieja, Działalność ukraińskich nacjonalistów na Ziemi Lubuskiej i przeciwdziałanie ze strony organów bezpieczeństwa i porzadku publicznego w latach 1947-1956, Legionowo 1981, typescript of diploma paper, c. 146. wania SB o sprawach pozostających w jej zainteresowaniu ${ }^{123}$.

Jednym z pierwszych przedsięwzięć otwierających w skali całego kraju nowy etap inwigilacji Ukraińców było przeprowadzenie w IV kwartale 1970 r. tajnych badań ankietowych, którymi objęto b. członków i współpracowników OUN i UPA, żołnierzy SS „Galizien”, b. członków siatek dywersyjno-wywiadowczych i związanych z nimi tzw. meliniarzy, funkcjonariuszy policji ukraińskiej oraz osoby o poglądach „nacjonalistycznych”. Sporządzona, oparta na danych archiwalnych, licząca 32 punkty ankieta miała dać pełen obraz aktywności danej osoby (kontakty w kraju i za granicą, otrzymywanie i kolportaż literatury emigracyjnej, słuchanie obcych rozgłośni radiowych, szerzenie propagandy nacjonalistycznej, przekazywanie informacji ośrodkom emigracyjnym, aktualna postawa) oraz podejmowanych wobec niej w przeszłości przedsięwzięć ,, neutralizujących" (karalność, rozmowy profilaktyczne i ostrzegawcze, próby werbunku, usunięcia ze stanowisk społecznych i służbowych, ograniczenie możliwości wystąpień publicznych i publikacji). Na podstawie wyników ankiety podejmowano decyzję o kontynuacji, wszczęciu lub zaniechaniu rozpracowania ${ }^{124}$. W skali województwa zielonogórskiego analizie poddano materiały dotyczące 70 osób, w tym 4 ouenowców, 7 żołnierzy SS „Galizien”, 45 upowców, 1 członka tzw. bojówek dywersyjnych, 4 „meliniarzy” (czyli udzielających schro-

123 Ibidem, s. 348.

124 AIPN Po, 024/285, Ankieta, 5 XII 1970, k. 15-20. 
It was assumed in the operational action plan elaborated by the SB unit in KMiP MO in Zielona Góra that further operational ventures aimed at the Ukrainian minority would be based on the development of a qualitative and quantitative network of agents, especially Ukrainian intelligentsia (it was recommended to nominate candidates among students), working for political and social isolation and limiting the negative impact on the society of "political opponents in nationalist positions", disclosing of persons in contact with Ukrainian emigration to prevent the penetration of "hostile ideology", the elimination of sources of "leaks" of information from Poland to "hostile centers", controlling people who maintain direct or correspondence relations with citizens of Western countries, periodically examining the situation and moods in the Ukrainian community in order to identify forms and methods of influencing "hostile nationalist elements". In turn, the so-called preventive actions aimed at counteracting "hostile nationalist activity", undertaken in consultation with the Division III of KW MO and PZPR County Committee, were to include: clarification of the "purpose and nature of the diversionary activity of hostile immigration centers", making warnings, applying disciplinary and administrative measures, and restricting the ability of people of Ukrainian nationality to contact nationalist centers by the Passport Department ${ }^{126}$.

126 Ibidem, Stan bezpieczeństwa za lata 19651970 w mieście i powiecie Zielona Góra w zakresie pionu III, 10 I 1971, c. 41-42. nienia ukraińskim kurierom) i 9 osób „powiązanych w przeszłości z ośrodkami”'125.

W opracowanym przez referat SB w KMiP MO w Zielonej Górze planie działań operacyjnych na rok 1971 zakładano, że dalsze przedsięwzięcia operacyjne wymierzone w mniejszość ukraińską będą polegały na: rozbudowie jakościowej i ilościowej sieci agenturalnej obejmującej zwłaszcza inteligencję ukraińską (zalecono typować kandydatów wśród studentów); działaniach na rzecz politycznej i społecznej izolacji oraz ograniczenia ujemnego wpływu na otoczenie „przeciwników politycznych, trwających na pozycjach nacjonalistycznych"; ujawnianiu osób kontaktujących się z emigracją ukraińską celem zapobieżenia przenikania „wrogiej ideologii”, likwidowaniu źródeł "przecieków” informacji z Polski do „wrogich ośrodków”; kontrolowaniu osób utrzymujących kontakty bezpośrednie lub korespondencyjne z obywatelami państw zachodnich, okresowym badaniu sytuacji i nastrojów w środowisku ukraińskim celem rozpoznania form i metod oddziaływania „wrogich elementów nacjonalistycznych". Z kolei tzw. działania profilaktyczne, zapobiegające „wrogiej działalności nacjonalistycznej", podejmowane $\mathrm{w}$ porozumieniu $\mathrm{z}$ Wydziałem III KW MO i Komitetem Powiatowym PZPR miały obejmować: wyjaśnianie „celu i charakteru dywersyjnej działalności wrogich ośrodków emigracyjnych"; rozmowy ostrzegawcze, wnioskowanie posunięć dyscyplinarnych $i$ administracyjnych oraz

125 AIPN, 1509/1774, M. Śmieja, Działalność ukraińskich nacjonalistów na Ziemi Lubuskiej i przeciwdziałanie ze strony organów bezpieczeństwa i porzadku publicznego w latach 1947-1956, Legionowo 1981, maszynopis pracy dyplomowej, k. 146. 
In the latter case, foreign trips were prevented to those who were feared would start activity detrimental to the interests of the Polish People's Republic were not allowed to go abroad ${ }^{127}$. The temporary departure of those citizens who had been unintentionally confined to their intent to remain in the West was also prevented.

Despite the fact that many operational directions were included in the workplans, the main effort was directed to the control of UTSK's activities. Special attention was paid to activists who, using the legitimate forms of activity of the Society, sought to "awaken the nationalist spirit and inhibit the natural process of assimilation"128. These people, most often referred to as "nationalists", were intended to remove from the boards of the circles and separate from further social work ${ }^{129}$. The reconstruction of the provincial structures of the Society was effectively sabotaged ${ }^{130}$. Security officers took, as we can suppose, the final decision on the alloca-

127 The Łowczanin married couple from Dragowina (the Zielona Góra country), who had been sentenced to long terms of imprisonment for underground activity, were not allowed to leave for the USA in 1970.

128 In the plan of the SB unit in Zielona Góra for 1972 those were intended to be under constant surveillance: S. Kułyk, A. Pidłypczak, J. Jurczyk, M. Zelen, J. Hrycaj, M. Tychanycz, M. Szlachtycz, B. Hondzio, W. Bagan and M. Dorocki (ibidem, Kierunkowy plan pracy SB KMiP MO na okres 1 I-31 XII 1972 r., 3 I 1972, c. 151).

129 AINR Sz, 004/31, Wniosek o wszczęcie sprawy obiektowej kryptonim “Beta-1", 9 XI 1970, c. 4.

130 AINR Po, 060/97, vol. 8, Stan bezpieczeństwa za lata 1965-1970 w mieście i powiecie Zielona Góra w zakresie pionu III, 10 I 1971, c. 40. ograniczenie możliwości kontaktów osób narodowości ukraińskiej z ośrodkami nacjonalistycznymi za pośrednictwem Wydziału Paszportów ${ }^{126}$. W ostatnim przypadku uniemożliwiano wyjazdy zagraniczne osobom, które, jak się obawiano, podjęłyby szkodliwą dla interesów PRL działalność ${ }^{127}$. Profilaktycznie blokowano też wyjazd czasowy tych obywateli, którzy nieopatrznie zwierzyli się otoczeniu z zamiaru nielegalnego pozostania na Zachodzie.

Mimo uwzględniania w planach pracy wielu kierunków działań operacyjnych, w praktyce główny wysiłek wkładano w kontrolę działalności UTSK. Szczególną uwagę zwracano na aktywistów, którzy wykorzystując legalne formy działalności Towarzystwa, dążyli do „budzenia ducha nacjonalistycznego i hamowania naturalnego procesu asymilacji”"128. Osoby te, określane najczęściej mianem "nacjonalistów”, zamierzano usunąć z zarządów kół i odseparować od dalszej pracy społecznej ${ }^{129}$. Skutecznie sabotowano odbudowę struktur wojewódzkich Towarzystwa ${ }^{130}$. Do funk-

126 Ibidem, Stan bezpieczeństwa za lata 19651970 w mieście i powiecie Zielona Góra w zakresie pionu III, 10 I 1971, k. 41-42.

127 W 1970 r. uniemożliwiono wyjazd do USA małżeństwu Łowczaninów z Drągowiny (powiat Zielona Góra), którzy byli niegdyś skazani na długoletnie więzienie za działalność w podziemiu.

128 W planie pracy referatu SB w Zielonej Górze na 1972 r. zalecano stałą kontrolą operacyjną otoczyć: S. Kułyka, A. Pidłypczaka, J. Jurczyka, M. Zelena, J. Hrycaja, M. Tychanycza, M. Szlachtycza, B. Hondzio, W. Bagana i M. Dorockiego (ibidem, Kierunkowy plan pracy SB KMiP MO na okres 1 I-31 XII 1972 r., 3 I 1972, k. 151).

129 AIPN Sz, 004/31, Wniosek o wszczęcie sprawy obiektowej kryptonim „Beta-1”, 9 XI 1970, k. 4.

130 AIPN Po, 060/97, t. 8, Stan bezpieczeństwa za lata 1965-1970 w mieście i powiecie Zielona Góra w zakresie pionu III, 10 I 1971, k. 40. 
tion of premises to the Society ${ }^{131}$. Similar moves to slow down the UTSK development were made in the Gorzów region. There, the local structures of the SB cooperated with the administrative authorities on several occasions forced removing Michał Kowalski from the board of the circle in Gorzów Wielkopolski, counting on the decline of his activity ${ }^{132}$. Attempts to establish the Society's units in other localities were also paralyzed ${ }^{133}$. All the events organized by the Society were secured by sending an agent to them, but also, if necessary, the officers of the Division "B" (external observation unit) of KW MO who carefully recorded the behavior of selected persons ${ }^{134}$.

At the request of Department III of the Ministry of Interior the preparations of local activists for the meeting in Warsaw were meticulously observed to ensure the "correct" course of the national congresses (V and VI falling in succession for the years 1972 and 1976) and the "proper" staffing of its Central Board. Probably this problem became the subject of interviews between $\mathrm{SB}$ officers and the staff of the Office/Departments of the Interior. At the beginning of 1972 the agents were in-

131 AINR Po, 024/285, Notatka służbowa, 26 X 1975 , c. $40-41$.

132 AINR Sz, 004/31, Ocena stanu bezpieczeństwa w sprawie obiektowej kryptonim "Beta-1", prowadzonej na mniejszość ukraińską za 1973 rok, 9 I 1974, c. 22; ibidem, Ocena stanu bezpieczeństwa w sprawie obiektowej kryptonim "Beta", prowadzonej na mniejszość ukraińską za 1977 rok, 10 I 1978, c. 39.

133 Ibidem, Ocena stanu bezpieczeństwa w sprawie obiektowej "Beta" prowadzonej na mniejszość ukraińską za 1977 r., 10 I 1978, c. 39.

134 S. Dudra, Poza mała ojczyzna..., p. 187. cjonariuszy aparatu bezpieczeństwa należała też, jak można przypuszczać, ostateczna decyzja dotycząca przydziału lokalu na działalność Towarzystwa ${ }^{131}$. Podobne posunięcia, które miały wyhamować rozwój UTSK, podejmowano w regionie gorzowskim. Tam miejscowe struktury SB, współdziałając $\mathrm{z}$ władzami administracyjnymi, kilkakrotnie wymuszały usunięcie Michała Kowalskiego z zarządu koła Gorzowie Wielkopolskim, licząc na spadek jego aktywności ${ }^{132}$. Paraliżowano także próby powołania ogniw Towarzystwa $\mathrm{w}$ innych miejscowościach ${ }^{133}$. Standardowo zabezpieczano wszystkie imprezy organizowane przez Towarzystwo, wysyłając nań agenturę, ale i w razie potrzeby także funkcjonariuszy Wydziału „B” (pion obserwacji zewnętrznej) KW MO, którzy wnikliwie rejestrowali zachowanie wybranych osób ${ }^{134}$.

Celem zapewnienia "prawidłowego" przebiegu krajowych zjazdów (V i VI przypadające kolejno na lata 1972 i 1976) Towarzystwa oraz „właściwej” obsady personalnej jego Zarządu Głównego na polecenie Departamentu III MSW skrupulatnie obserwowano przygotowania lokalnych aktywistów do spotkania w Warszawie. Zapewne problem ten stał się tematem rozmów funkcjonariuszy SB i pracowników

131 AIPN Po, 024/285, Notatka służbowa, 26 X 1975, k. 40-41.

132 AIPN Sz, 004/31, Ocena stanu bezpieczeństwa w sprawie obiektowej kryptonim „Beta-1”, prowadzonej na mniejszość ukraińską za 1973 rok, 9 I 1974, k. 22; ibidem, Ocena stanu bezpieczeństwa w sprawie obiektowej kryptonim „Beta”, prowadzonej na mniejszość ukraińską za 1977 r., 10 I 1978, k. 39.

133 Ibidem, Ocena stanu bezpieczeństwa w sprawie obiektowej „Beta” prowadzonej na mniejszość ukraińską za 1977 r., 10 I 1978, k. 39.

134 S. Dudra, Poza mała ojczyzną..., s. 187. 
structed to learn about: delegates from the Zielona Góra province, the problems that they were about to raise and people who were selected to the central UTSK authorities. Operational-survey interviews were conducted with the indicated representatives of the Ukrainian community "in order to find out the troublesome issues of the local UTSK circle that they may possibly touch at the Convention". This is probably the way some people were brought to work, most often as operational contacts ${ }^{135}$.

While the presentation of the general outlook of surveillance of the entire Ukrainian environment or UTSK in Ziemia Lubuska does not make it more difficult, problems arise during the analysis of religious issues. In theory, this sphere of activity of the Ukrainian minority was subordinated to Sections III of the Divisions IV of the Provincial Headquarters of MO. Thanks to information from centrallevel consultations and operational materials from other provinces, we can suppose that the surveillance of Greek Catholic priests and parishioners in Ziemia Lubuska took place within the context of an object case codenamed "Ortodox" (or "Ortodoks[i]") 136 . According to the work

135 AINR Po, 060/97, vol. 8, Kierunkowy plan pracy SB KMiP MO na okres 1 I-31 XII 1972 r., 3 I 1972, c. $151 \mathrm{v}$.

136 See: Plany pracy Departamentu IV MSW na lata 1972-1979, introduction P. Tomasik; selection and redaction M. Biełaszko, A. K. Piekarska, P. Tomasik i C. Wilanowski, Warszawa 2007, doc. No. 4, Plan pracy Wydziału III Departamentu IV MSW na lata 1972/1973, 15 III 1972, p. 37; s. 112; ibidem, doc. No. 16, Plan pracy Wydziału III Departamentu IV MSW na lata 1974-1975, 3 I 1974, p. 112; ibidem, doc. No. 23, Plan pracy Wydziału III Departamentu
Urzędu/Wydziałów Spraw Wewnętrznych. Na początku 1972 r. polecono agenturze ustalić: delegatów $\mathrm{z}$ województwa zielonogórskiego; problemy, które ci zamierzali poruszyć, oraz osoby typowane do centralnych władz UTSK. Ze wskazanymi przedstawicielami środowiska ukraińskiego przeprowadzano rozmowy operacyjno-sondażowe „w celu zorientowania się w nurtujących problemach tutejszego koła UTSK, które ewentualnie mogą poruszyć na Zjeździe". Zapewne w ten sposób część osób pozyskano do współpracy, najczęściej w charakterze kontaktów operacyjnych ${ }^{135}$.

O ile przedstawienie ogólnego zarysu inwigilacji całego środowiska ukraińskiego czy też UTSK na Ziemi Lubuskiej nie sprawia większej trudności, o tyle problemy pojawiają się $\mathrm{w}$ trakcie analizy problematyki wyznaniowej. Teoretycznie ta sfera aktywności mniejszości ukraińskiej podlegała sekcjom III wydziałów IV komend wojewódzkich MO. Dzięki informacjom z narad na szczeblu centralnym i materiałom operacyjnym $\mathrm{z}$ innych województw możemy przypuszczać, że inwigilacja księży greckokatolickich i parafian $\mathrm{w}$ regionie lubuskim odbywała się w ramach sprawy obiektowej o kryptonimie „Ortodox” (względnie „Ortodoks[i]”) ${ }^{136}$. Jak wynika

135 AIPN Po, 060/97, t. 8, Kierunkowy plan pracy SB KMiP MO na okres 1 I-31 XII 1972 r., 3 I 1972, k. 151v.

136 Na ten temat zob. Plany pracy Departamentu IV MSW na lata 1972-1979, wstęp P. Tomasik; wybór i oprac. M. Biełaszko, A.K. Piekarska, P. Tomasik, C. Wilanowski, Warszawa 2007, dok. nr 4, Plan pracy Wydziału III Departamentu IV MSW na lata 1972/1973, 15 III 1972, s. 37; s. 112; ibidem, dok. nr 16, Plan pracy Wydziału III Departamentu IV MSW na lata 1974-1975, 3 I 1974, s. 112; ibidem, dok. nr 23, Plan pracy Wydziału III Departamentu IV MSW na lata 1976-1977, 12 I 1976, s. 178; J. Syr- 
plans, the main assumptions of which were elaborated in Division III of the Department IV of the Ministry of Interior, the emphasis was on investigating the contacts of the clergy with the Ukrainian emigre centers, conducting disintegration projects within the Greek Catholic Church, deepening grudges in contacts with the Roman Catholic clergy, and paralyzing the recruitment of candidates of Ukrainian nationality for seminars, especially those located outside the country and strengthening the position of the Orthodox Church in the regions of the operation of the Uniate priests $^{137}$. However, in the light of documents from Ziemia Lubuska and Pomorze Zachodnie it seems that the SB "religious" division organized in the MO provincial headquarters underestimated the Greek Catholic issue ${ }^{138}$. In practice, its tasks were taken over by units responsible for "fighting Ukrainian nationalism" (that is, in fact, the comprehensive control of the Ukrain-

IV MSW na lata 1976-1977, 12 I 1976, p. 178; J. Syrnyk, Sprawa obiektowa "Ortodox" na terenie województwa legnickiego - przyczynek do badań nad rozpracowaniem Cerkwi greckokatolickiej przez aparat bezpieczeństwa PRL, [in:] Ukraińcy w najnowszych dziejach Polski 1918-1989, vol. 3, edit. R. Drozd, Słupsk 2007, pp. 215-230; I. Hałagida, "Szpieg Watykanu". Kapłan greckokatolicki ks. Bazyli Hrynyk (1896-1977), Warszawa 2008, pp. 263-264.

137 AINR Sz, 00103/152, vol. 63, Ramowy zakres pracy i regulamin organizacyjny Wydziału IV KW MO w Koszalinie, 20 III 1973, c. 236.

138 This indirectly indicates the statement of the officers of the Division III of the KW MO in Gorzów: "The activities of the Greek Catholic clergy, topics of talks, intentions, unofficial contacts of priests with the Ukrainian people are unrecognized" (AINR Sz, 004/31, Ocena stanu bezpieczeństwa w sprawie obiektowej "Beta” prowadzonej na mniejszość ukraińską, 20 I 1976, c. 34). z planów pracy, których główne założenia opracowano w Wydziale III Departamentu IV MSW, nacisk kładziono na: zbadanie kontaktów duchowieństwa z ukraińskimi ośrodkami emigracyjnymi, prowadzenie przedsięwzięć dezintegracyjnych wewnątrz wspólnoty greckokatolickiej, pogłębianie niesnasek w kontaktach $\mathrm{z}$ duchowieństwem rzymskokatolickim oraz paraliżowanie naboru kandydatów narodowości ukraińskiej do seminariów, zwłaszcza tych znajdujących się poza granicami kraju oraz umacnianie pozycji Kościoła prawosławnego w rejonach działania księży unickich ${ }^{137}$. Jednak w świetle dokumentów z Ziemi Lubuskiej i Pomorza Zachodniego wydaje się, że pion „wyznaniowy” SB zorganizowany w tamtejszych komendach wojewódzkich MO bagatelizował zagadnienie greckokatolickie ${ }^{138}$. W praktyce jego zadania przejmowały komórki odpowiedzialne za "zwalczanie nacjonalizmu ukraińskiego" (czyli na dobrą sprawę kompleksową kontrolę Ukraińców). To ich agentura zapewniała „bieżący dopływ informacji o zamierzeniach i podejmowanej przez

nyk, Sprawa obiektowa „Ortodox” na terenie województwa legnickiego - przyczynek do badań nad rozpracowaniem Cerkwi greckokatolickiej przez aparat bezpieczeństwa PRL, [w:] Ukraincy w najnowszych dziejach Polski 1918-1989, t. 3, red. R. Drozd, Słupsk 2007, s. 215-230; I. Hałagida, „Szpieg Watykanu”. Kapłan greckokatolicki ks. Bazyli Hrynyk (1896-1977), Warszawa 2008, s. 263-264.

137 AIPN Sz, 00103/152, t. 63, Ramowy zakres pracy i regulamin organizacyjny Wydziału IV KW MO w Koszalinie, 20 III 1973, k. 236.

138 Pośrednio wskazuje na to stwierdzenie funkcjonariuszy Wydziału III KW MO w Gorzowie: „Nierozpoznana jest działalność kleru greckokatolickiego, tematyka rozmów, zamierzeń, nieoficjalnych kontaktów księży z ludnością ukraińską" (AIPN Sz, 004/31, Ocena stanu bezpieczeństwa w sprawie obiektowej „Beta” prowadzonej na mniejszość ukraińską, 20 I 1976, k. 34). 
ians). They were their agents that ensured "the current flow of information about intentions and hostile or harmful activities undertaken by the clergy". In December 1974, the SB in Zielona Góra ordered SC pseud. "Jacek" "during the holidays to attend church services [in the St. Jadwiga church] and hear the main sermons. Important moments to note and forward at the next meeting" ${ }^{139}$. The work plans of this unit for the following year included "deepening the operational surveillance of the Orthodox and Greek Catholic clergy and activists of this religion in the area, to prevent them from organizing collections of funds for building churches, or making efforts in this regard" 140 . Since 1977, secret collaborators "Cora", "Marian" and "Stefan" were observing the pastoral work of Fr. Rożak "in the aspect of his impact on the Ukrainian environment, shaping the specific attitudes and behavior of the Ukrainian population living here"141. Probably, cases of making Ukrainian gravestone inscriptions in local cemeteries were also recorded. In the Gorzów region in 1975 only two such cases were reported. One of the inscriptions was destroyed by "unknown perpetrators"142. The most valuable information was given to the officers of the

139 AINR Po, 024/500, Notatka służbowa z odbytego spotkania z TW ps. Jacek, 12 XII 1974, c. 27.

140 AINR Po, 060/97, vol. 8, Kierunkowy plan pracy SB KPiM MO w mieście i powiecie Zielona Góra na rok 1975, 10 I 1975, c. 235 and 235v.

141 AINR Po, 024/500, Wyciąg z notatki służbowej ze spotkania z TW ps. "Cora", 6 I 1978, c. 73.

142 AINR Sz, 004/31, Ocena stanu bezpieczeństwa w sprawie obiektowej kryptonim "Beta" prowadzonej na mniejszość ukraińską, 20 I 1976, c. 32. kler wrogiej lub szkodliwej działalności”. W grudniu 1974 r. zielonogórska SB poleciła TW ps. „Jacek” „w czasie świąt brać udział w nabożeństwach [w kościele pw. św. Jadwigi] i wysłuchać główne kazania. Ważniejsze momenty notować i przekazać na następnym spotkaniu"139. W planach pracy tej jednostki „bezpieki” na następny rok uwzględniono „pogłębienie operacyjnego rozpoznania kleru prawosławnego i greckokatolickiego oraz działaczy tego wyznania na tutejszym terenie w celu niedopuszczenia do organizowania zbiórek na budowę kościoła, względnie podejmowania starań w tym zakresie"140. Od 1977 r. tajni współpracownicy „Cora”, „Marian” i „Stefan” obserwowali pracę duszpasterską ks. Rożaka „w aspekcie jego oddziaływania na środowisko ukraińskie, kształtowanie przez niego określonych postaw i zachowań zamieszkałej tu ludności ukraińskiej" ${ }^{141}$. Prawdopodobnie rejestrowano też przypadki sporządzenia w ostatnich latach inskrypcji nagrobnych w języku ukraińskim na lokalnych cmentarzach. $\mathrm{W}$ regionie gorzowskim w $1975 \mathrm{r}$. odnotowano jedynie dwa takie przypadki. Jeden z napisów został zniszczony przez „nieznanych sprawców"142. Najbardziej wartościowe informacje przekazywano funkcjonariuszom z pionu wyznaniowego, którzy na tej podstawie prawdopodobnie sporządzali ogól-

139 AIPN Po, 024/500, Notatka służbowa z odbytego spotkania z TW ps. Jacek, 12 XII 1974, k. 27.

140 AIPN Po, 060/97, t. 8, Kierunkowy plan pracy SB KPiM MO w mieście i powiecie Zielona Góra na rok 1975, 10 I 1975, k. 235 i 235v.

141 AIPN Po, 024/500, Wyciąg z notatki służbowej ze spotkania z TW ps. „Cora”, 6 I 1978, k. 73.

142 AIPN Sz, 004/31, Ocena stanu bezpieczeństwa w sprawie obiektowej kryptonim „Beta” prowadzonej na mniejszość ukraińską, 20 I 1976, k. 32. 
religious division, who were likely to make a general analysis on this basis ${ }^{143}$. Cooperation with them was also continued after 1975 , i.e. after the administrative reform resulting in the reconstruction of regional structures of SB. "Cooperate with the Division IV of KW MO in the field of religious activities undertaken by the Greek Catholic clergy and in the exchange of information about the intentions and influence of the Ukrainian priests on the population" wrote representatives of the Division III of KW MO in Gorzow Wielkopolski in January $1977^{144}$.

The event, which at the end of the seventies significantly affected the scope of operational work of SB (also in the Ukrainian environment), was the first pilgrimage of Pope John Paul II to Poland in June 1979. Its "safety" took place under a broadbased operation under the name "Lato 79". In the case of the Greek Catholics, the "security" was afraid of using their opportunity to renew their efforts to rebuild legitimate church structures. In order to prevent this, the agent network was instructed to observe those who were meeting with the Pope, and to record cases of signing petitions. The personal sources of information were also used to relate the references to the pilgrimage included in the ser-

143 Thus, in the SB Unit of Municipal and County Headquarters in Gorzów, Lieutenant Henryk Wyśmierski, who surveilled the local Ukrainians, provided information on Father Rosiecki to Capt. Tadeusz Brzozowski, who dealt with religious issues.

144 AINR Sz, 004/31, Ocena stanu bezpieczeństwa w sprawie obiektowej kryptonim "Beta" prowadzonej na mniejszość ukraińską za rok 1976, 4 I 1977, c. 38. ne analizy ${ }^{143}$. Współpracę z nimi kontynuowano także po 1975 r., czyli po reformie administracyjnej skutkującej przebudową struktur terenowych SB. „Współdziałać z Wydziałem IV KW MO na odcinku podejmowanych działań zabezpieczających sprawy religijne organizowane przez kler greckokatolicki oraz w zakresie wymiany informacji o zamierzeniach i oddziaływaniu księży ukraińskich na ludność" - napisali w styczniu 1977 r. przedstawiciele Wydziału III KW MO w Gorzowie Wielkopolskim $^{144}$.

Wydarzeniem, które u schyłku lat 70. wpłynęło w znaczący sposób na zakres pracy operacyjnej SB (także w środowisku ukraińskim), była pierwsza pielgrzymka papieża Jana Pawła II do Polski w czerwcu 1979 r. Jej „zabezpieczenie” odbywało się w ramach szeroko zakrojonej operacji pod nazwą "Lato 79”. W przypadku grekokatolików „bezpieka” obawiała się wykorzystania przez nich okazji do wznowienia starań na rzecz odbudowy legalnych struktur kościelnych. Aby temu zapobiec, polecono sieci agenturalnej obserwować osoby wybierające się na spotkanie z papieżem oraz rejestrować przypadki zbierania podpisów pod petycjami. Nakazano także osobowym źródłom informacji relacjonować odniesienia do pielgrzym-

${ }^{143}$ I tak w Referacie ds. Służby Bezpieczeństwa KM i P MO w Gorzowie por. Henryk Wyśmierski rozpracowujący miejscowych Ukraińców przekazywał informacje na temat księdza Rosieckiego kpt. Tadeuszowi Brzozowskiemu zajmującemu się problematyką wyznaniową.

144 AIPN Sz, 004/31, Ocena stanu bezpieczeństwa w sprawie obiektowej kryptonim „Beta” prowadzonej na mniejszość ukraińską za rok 1976, 4 I 1977, k. 38. 
mons of Greek Catholic priests and to the conversations of lay people ${ }^{145}$.

The almost complete lack of source materials prevents Studying the issue of the development of Ukrainians in Ziemia Lubuska after 1980. Based on the few local documents that survived the destruction of the files, the archives of the Departments III and IV of the Ministry of Interior and other voivodship units, it can be stated with certainty that the Ukrainian community in the Gorzów and Zielona Góra provinces was "under special supervision" until January 1990. That is until the formal termination of the object case codenamed "Beta"146.

\section{Abstract}

Settled after the "Vistula" Operation in Ziemia Lubuska, the Ukrainian population was supervised by the communist security apparatus. All displaced people were subjected to surveillance, irrespective of the degree of loyalty to the new authority. Operational work on Ukrainians was conducted with varying intensity throughout all the period of the People's Republic of Poland. The actions taken were not only aimed at "neutralizing" anti-systemic behavior but also accelerating the integration and assimilation processes. The repression of the Ukrainian population, the reduction of contacts with the compatriots abroad, and the paralysis of social and religious activity were to become effective means of accelerating the loss of national, cultural and religious diversity.

145 Archive of the Institue of National Remeberance in Gdańsk (AINR Gd), 002/37, vol. 6, Raport z odbytego spotkania z TW "Daniel", 26 V 1979, c. 67; ibidem, Informacja TW "Borys", 26 V 1979, c. 73; AINR Po, 024/500, Meldunek operacyjny, 12 VI 1979, c. 101.

146 AINR Sz, 004/31, Meldunek o zakończeniu sprawy obiektowej o kryptonimie "Beta", 4 I 1990, c. 54 . ki zawarte w kazaniach księży greckokatolickich i rozmowach ludzi świeckich ${ }^{145}$.

Zbadanie zagadnienia rozpracowania Ukraińców w regionie lubuskim po $1980 \mathrm{r}$. uniemożliwia niemal całkowity brak materiałów źródłowych. Opierając się na nielicznych lokalnych dokumentach, które przetrwały akcję niszczenia akt, archiwaliach Departamentów III i IV MSW oraz innych jednostek wojewódzkich, można jednak z całą pewnością stwierdzić, że społeczność ukraińska w województwach gorzowskim i zielonogórskim znajdowała się „pod specjalnym nadzorem” aż do stycznia 1990 r., czyli do chwili formalnego zakończenia spraw obiektowych o kryptonimie „Beta” ${ }^{146}$.

\section{Abstrakt}

Osiedlona po akcji „Wisła” na Ziemi Lubuskiej ludność ukraińska poddana została nadzorowi przez komunistyczny aparat bezpieczeństwa. Inwigilowano wszystkich przesiedleńców, bez względu na wykazywany stopień lojalności wobec nowej władzy. Praca operacyjna wobec Ukraińców była prowadzona $\mathrm{z}$ różnym natężeniem w całym okresie Polski Ludowej. Podejmowane działania miały na celu nie tylko „zneutralizować” zachowania antysystemowe, ale też przyspieszyć procesy integracyjne i asymilacyjne. Represjonowanie ludności ukraińskiej, ograniczenie kontaktów z rodakami za granicą, a także paraliżowanie działalności społecznej i religijnej miało stać się skutecznym środkiem przyspieszającym utratę odrębności narodowej, kulturowej i wyznaniowej.

145 Archiwum Instytutu Pamięci Narodowej w Gdańsku (AIPN Gd), 002/37, t. 6, Raport z odbytego spotkania z TW „Daniel”, 26 V 1979, k. 67; ibidem, Informacja TW „Borys”, 26 V 1979, k. 73; AIPN Po, 024/500, Meldunek operacyjny, 12 VI 1979, k. 101.

146 AIPN Sz, 004/31, Meldunek o zakończeniu sprawy obiektowej o kryptonimie „Beta”, 4 I 1990, k. 54 . 


\section{Bibliography / Bibliografia}

Akcja "Wisła”. Dokumenty, edit. E. Misiło, Warszawa 1993.

Balbus T., Rozpracowanie agenturalne środowisk ukrainskich w Polsce w 1949 roku, "Biuletyn Instytutu Pamięci Narodowej" 2001, No. 8.

Chabasińska A., Kościół prawosławny na Ziemi Lubuskiej po II wojnie światowej, "Studia Lubuskie" 2010, vol. 6.

Drozd R., Polityka władz wobec ludności ukraińskiej w Polsce w latach 1944-1989, Warszawa 2001.

Dudra S., Łemkowie. Deportacja i osadnictwo ludności łemkowskiej na Środkowym Nadodrzu w latach 1947-1960, Głogów 1998.

Hałagida I., "Szpieg Watykanu”. Kapłan greckokatolicki ks. Bazyli Hrynyk (1896-1977), Warszawa 2008.

Hałagida I., Prowokacja "Zenona”. Geneza, przebieg i skutki operacji MBP o kryptonimie "C-1" przeciwko banderowskiej frakcji OUN $i$ wywiadowi brytyjskiemu (1950-1954), Warszawa 2005.

Kwestia ukraińska $w$ działalności Stużby Bezpieczeństwa PRL. Dokumenty i materiał, introdaction and edit. A. Słabig, Warszawa 2016.

Majewski M., Teodor Dak i operacja "Pająki”, [in:] Służby bezpieczeństwa Polski i Czechosłowacji wobec Ukrainców, edit. G. Motyka, Warszawa 2005.

Musiał F., Podręcznik bezpieki. Teoria pracy operacyjnej Służby Bezpieczeństwa w świetle wydawnictw resortowych Ministerstwa Spraw Wewnętrznych PRL (1970-1989), Kraków 2007.

Paczkowski A., Pół wieku dziejów Polski 1939-1989, Warszawa 1995.

Plany pracy Departamentu IV MSW na lata 1972-1979, introduction P. Tomasik, selection and edit. M. Biełaszko, A.K. Piekarska, P. Tomasik, C. Wilanowski, Warszawa 2007.

Słabig A., Od rozpracowania "elementów bandyckich" do przyspieszenia "naturalnej" asymilacji. Zarys działań aparatu bezpieczeństwa wobec Ukraińców na Ziemi Lubuskiej w latach 1947-1970, [in:] Przed i po akcji “Wisła”, edit. A. Chabasińska, P. Leszczyński, B. Orłowska, M. Pecuch, Gorzów Wielkopolski 2012.

Słabig A., W kręgu sprawy pod kryptonimem "Beta”. Ludność ukraińska na Ziemi Lubuskiej w latach 1970-1980 w świetle materiałów Stużby Bezpieczeństwa, "Studia Zachodnie" 2012, No. 14.

Spohad Iwana Olijara, [in:] Zakerzonnia. Spomynywojakiw UPA, vol. 4, red. B. Huk, Warszawa 1998.

Syrnyk J., "Po linii" rewizjonizmu, nacjonalizmu, syjonizmu... Aparat bezpieczeństwa wobec ludności niepolskiej na Dolnym Ślasku (1945-1989), Wrocław 2013.

Syrnyk J., Ludność ukraińska na Dolnym Śląsku (1945-1989), Wrocław 2007.

Syrnyk J., Organizacja pracy organów bezpieczeństwa w zakresie działania wobec ludności ukraińskiej na Dolnym Ślasku (1947-1989), http://www.iukraina.pl [access on: 10.05.2012].

Syrnyk J., Sprawa obiektowa "Ortodox" na terenie województwa legnickiego - przyczynek do badań nad rozpracowaniem Cerkwi greckokatolickiej przez aparat bezpieczeństwa PRL, [in:] Ukraińcy w najnowszych dziejach Polski 1918-1989, t. III, edit. R. Drozd, Słupsk 2007.

Syrnyk J., Ukrainskie Towarzystwo Społeczno-Kulturalne (1956-1990), Wrocław 2008.

Śmieja M., Działalność ukraińskich nacjonalistów na Ziemi Lubuskiej i przeciwdziałanie ze strony organów bezpieczeństwa i porządku publicznego w latach 1947-1956, Legionowo 1981, typescript.

Terlecki R., Miecz i tarcza komunizmu. Historia aparatu bezpieczeństwa w Polsce 1944-1990, Kraków 2008.

Article submitted: 05.02.2017; article accepted: 10.05.2017 